\title{
Fuel-nitrogen conversion in the combustion of small amines using dimethylamine and ethylamine as biomass-related model fuels
}

\author{
Arnas Lucassen ${ }^{1}$, Kuiwen Zhang ${ }^{1,2}$, Julia Warkentin ${ }^{1}$, Kai Moshammer ${ }^{1}$, Peter \\ Glarborg $^{3^{*}}$, Paul Marshall ${ }^{4}$, Katharina Kohse-Höinghaus ${ }^{1 *}$
}

${ }^{1}$ Department of Chemistry, Bielefeld University, Universitätsstraße 25, D-33615 Bielefeld, Germany;

${ }^{2}$ National Synchrotron Radiation Laboratory, University of Science and Technology of China, Hefei, Anhui 230029, China,

${ }^{3}$ Department of Chemical and Biochemical Engineering, Technical University of Denmark, Søltofts Plads, 2800 Kgs. Lyngby, Denmark

${ }^{4}$ Department of Chemistry and Center for Advanced Scientific Computing and Modeling, University of North Texas, 1155 Union Circle \#305070, Denton, Texas 76203-5017, USA *Corresponding authors, Email addresses: kkh@uni-bielefeld.de (K. Kohse-Höinghaus) and PGL@kt.dtu.dk (Peter Glarborg)

Keywords: molecular-beam mass spectrometry, dimethylamine, ethylamine, biofuels, premixed laminar flame

\footnotetext{
Abstract

Laminar premixed flames of the two smallest isomeric amines, dimethylamine and ethylamine, were investigated under one-dimensional low-pressure (40 mbar) conditions with the aim to elucidate pathways that may contribute to fuel-nitrogen conversion in the combustion of biomass. For this, identical flames of both fuels diluted with $25 \% \mathrm{Ar}$ were
} 
studied for three different stoichiometries $(\Phi=0.8,1.0$, and 1.3) using in situ molecular-beam mass spectrometry (MBMS). Quantitative mole fractions of reactants, products and numerous stable and reactive intermediates were determined by electron ionization (EI) MBMS with high mass resolution to separate overlapping features from species with different heavy elements by exact mass. Species assignment was assisted by using single-photon vacuumultraviolet (VUV) photoionization (PI) MBMS. The results indicate formation of a number of nitrogenated intermediates, including toxic species such as $\mathrm{HCN}$, in appreciable concentrations. Such intermediate species mole fractions may depend not only on stoichiometry, but also on fuel structure.

We attempted to analyze the major pathways in the two flames with a detailed combustion model developed for this purpose. For this, thermochemical values for a number of intermediates had to be determined from quantum chemistry calculations. Also, specific sets of reactions were incorporated for the two fuels. While many trends seen in the experiments can be successfully reproduced by the simulations, additional efforts may be needed to reliably describe the fuel-nitrogen chemistry in the combustion of biomass-related model fuels with amine functions.

\section{Introduction}

Fuel-nitrogen conversion chemistry, especially prediction of the formation of nitrogen oxides, $\mathrm{NO}_{\mathrm{x}}$, from combustion processes, remains an active subject of research since the first review by Miller and Bowman, more than two decades ago [1]. Several reasons contribute to this interest. First, detailed reaction schemes which keep track of the formation and destruction of small nitrogenated compounds in combustion, including e.g. $\mathrm{NO}, \mathrm{HCN}, \mathrm{NH}_{3}, \mathrm{HNO}$, and HNCO, and the dominant reactions that influence their interconversion have been investigated and discussed for a wide range of conditions [2-4]. Second, the introduction of alternative 
transportation fuels such as biodiesel has led to the re-evaluation of $\mathrm{NO}_{\mathrm{x}}$ formation [5], given that different fuel structures entail a different reactive species mix. Third, from the nitrogen content in solid biomass and in related matter, including agricultural waste, a diverse spectrum of volatile and heterogeneously fixed nitrogen-containing compounds can be expected, complicating the prediction of fuel-bound nitrogen conversion [6-9]. Finally, nitrogen conversion is being investigated regarding novel combustion strategies for power generation such as oxy-fuel combustion of coal and/or biomass [10-12], also requiring reevaluation of the pathways towards small nitrogen compounds.

It is interesting to note in this context that detailed studies of flames burning nitrogenated compounds are still quite scarce, especially under conditions where intermediate species concentration measurements and development of the respective combustion mechanisms are possible. Flames of or doped with ammonia have been investigated, with one recent study involving $\mathrm{CH}_{4} / \mathrm{NH}_{3}$ fuel mixtures and the analysis of their combustion with a flame model using a joint hydrocarbon/ammonia mechanism [13]. Several flames of heterocyclic compounds have also been studied, in part only providing species identification, however [14-16]. For fuels which feature an amine group, generally applicable detailed combustion mechanisms will need to be developed. Recent investigation of the combustion chemistry of morpholine as a potential model biofuel which presents a secondary amine and an ether function has reported a complex intermediate species pool, quantified from a combination of photoionization (PI) and electron ionization (EI) molecular beam mass spectrometry (MBMS) [17]. Modeling of this rich chemistry showed remarkable agreement for some of the small nitrogen compounds, but was not yet satisfactory to predict some steps in the early fuel decomposition leading to $\mathrm{NH}_{2}$ and $\mathrm{NH}_{3}$. Evidence from cavity ringdown spectroscopy (CRDS) experiments in this flame also showed early $\mathrm{NH}_{2}$ formation [18], and more information would be desirable on the thermochemistry and kinetics of potential further ammonia-related pathways. 
Regarding the complexity of the combustion chemistry of the cyclic amine morpholine, a reasonable strategy pursued here is to analyze flames of smaller amine fuels in more detail. Ethylamine (EA) and dimethylamine (DMA) are the simplest isomeric amines. Thus they are especially well suited for an investigation of the structure dependence of the combustion reactions of amines. These two amines are base structures for various substances used for instance for crop and wood protection, paints and finishes [19] as well as in aminebased fuel additives. Furthermore, dimethylamino groups are a common structural feature of hypergolic fuels [20]. Small amines also play an important role during the treatment of fish waste and its energetic use [21-23]. Only few early investigations of the combustion of these compounds are available, however [24,25]. Further work has focused on the oxidation behavior and the influence of amines on hydrocarbon combustion [26-30]. Sources of aliphatic amines from agricultural and industrial processes and from fish and meat production have been reviewed recently regarding their environmental impact [31,32], with EA and DMA belonging to the most abundant amines found in the atmosphere. Dimethylamine has also received attention as a precursor to carcinogenic substances in water treatment and the atmosphere [31-33].

In the present paper we therefore provide the first comprehensive analysis of laminar premixed, identical-condition flames of ethylamine and dimethylamine, with equivalence ratios $\Phi$ spanning a reasonable range from fuel-lean to slightly rich (i.e. $\Phi=0.8,1.0$, and 1.3). The information from the comparison of species concentration profiles between these isomeric flames is believed to contribute valuable insight also for the combustion of more complex fuel structures involving amine groups. Also, the combustion of these isomeric amines can be compared from structural analogies to those of the corresponding oxygenated compounds, dimethylether and ethanol [34-36], under similar conditions. 


\section{Experiment}

The experimental setups and procedures used here are quite comparable to those that have been recently employed in an investigation of the combustion of morpholine [17]. Therefore, only a very brief description is provided here. Three pairs of laminar, premixed flat flames of ethylamine and dimethylamine were investigated at 40 mbar and 25 vol\% argon dilution, a lean flame pair with $\Phi=0.8$ (abbreviated EA08 and DMA08, respectively), a stoichiometric one with $\Phi=1.0$ (EA10 and DMA10), and a slightly rich flame pair with $\Phi=1.3$ (EA13 and DMA13). The flames were stabilized on water-cooled flat flame burners with $6.34 \mathrm{~cm}$ and $6.0 \mathrm{~cm}$ diameter, respectively, for the EI-MBMS and PI-MBMS setups described below. Gas flows were metered using calibrated mass flow controllers. Flame conditions are given in Table 1. The flow rates were chosen so that the cold gas velocity was the same in both experiments.

Two MBMS instruments were used for the in situ analysis of the local flame composition. Typical results discussed here report species mole fraction profiles as a function of flame position $h$, i.e. height above the burner surface. They were mostly obtained with the MBMS setup located in Bielefeld using electron ionization. Identification of species by exact mass was possible due to the high mass resolution $(\mathrm{m} / \Delta m=4000)$ of the reflectron time-offlight (TOF) mass analyzer which allowed the separation of elemental compositions. Ionization relied on a pulsed electron beam of $\sim 10^{9}$ electrons/pulse with an energy distribution of $1 \mathrm{eV}$ (FWHM) which permitted to detect all species in the same mass spectrum. Different energies $(10.5 \mathrm{eV}, 12.0 \mathrm{eV}, 15 \mathrm{eV}$, and $17.5 \mathrm{eV})$ were employed to analyze the flame and to detect and minimize potential fragmentation.

In addition, isomer separation was possible in some cases with the MBMS instrument based at the Advanced Light Source in Berkeley which used single-photon photoionization with continuous, high-intensity $\left(\sim 10^{13}\right.$ photons/s) synchrotron-generated vacuum ultraviolet 
radiation. Its competitive energy resolution $(\Delta E=0.05 \mathrm{eV})$ permitted the identification of flame species via their ionization thresholds, whereas the mass resolution of its linear TOF was limited to $m / \Delta m=400$.

Gas samples were taken from the flame with quartz nozzles; they featured orifice diameters at the tip of $0.5 \mathrm{~mm}$ in the EI-MBMS and $0.4 \mathrm{~mm}$ in the PI-MBMS experiment, and an angle of $25^{\circ}$ (EI-MBMS) or $40^{\circ}$ (PI-MBMS), respectively. A molecular beam was formed with two differential pumping stages; the pressure was kept at $\sim 10^{-4}$ mbar in the first stage and at $\sim 10^{-6}$ mbar in the ionization region behind a skimmer. Ions were detected using a multichannel plate and were integrated with a multichannel scaler with a sensitivity of $\sim 10^{-5}$, and mass spectra were collected for typically $10^{5}$ ionization pulses as a function of position in the flame or of ionization energy at given position. Spectra were corrected for fragmentation and isotopic contributions of ${ }^{13} \mathrm{C}$ and ${ }^{18} \mathrm{O}$.

The major species mole fractions were determined with calibration mixtures of known gas composition, and by taking the elemental balances of carbon, hydrogen, oxygen, and nitrogen into consideration. In this evaluation, the gas composition at the burner surface was assumed to be represented by EA or DMA, $\mathrm{O}_{2}$, and Ar. The burnt gases at the farthest distance from the burner were assumed to consist of $\mathrm{Ar}$ and the products $\mathrm{CO}, \mathrm{CO}_{2}, \mathrm{H}_{2}, \mathrm{H}_{2} \mathrm{O}$, $\mathrm{N}_{2}$, and NO. (The mole fractions of $\mathrm{NH}_{3}$ and $\mathrm{HCN}$ at this position turned out to be small enough for this assumption to be reasonable.) The mole fractions of these products in the exhaust gas were derived from the measured ratios of $\mathrm{CO} / \mathrm{CO}_{2}$ and $\mathrm{NO} / \mathrm{N}_{2}$ using the respective element balances, then assuming the remaining oxygen to be bound in $\mathrm{H}_{2} \mathrm{O}$, and, with the $\mathrm{H}_{2} \mathrm{O}$ mole fraction determined, the remaining hydrogen bound in $\mathrm{H}_{2}$. The estimated uncertainty of this procedure in these flames featuring compounds with four elements is less than $30 \%$, and it can be seen from the major species mole fraction profiles, provided further below, that the approximations used are quite reasonable for the range of stoichiometries investigated here. 
Intermediate species mole fractions were determined by either using absolute ionization cross sections or calibration factors from cold gas measurements. The detailed procedures for this analysis have been reported in [17]. Briefly, the signal $S_{i}(E)$ of a species $i$ at the energy $E$ is given by

$$
S_{i}=p_{i} \cdot c \cdot S W \cdot D_{i} \cdot \varphi \cdot F K T(h) \cdot \int \sigma_{i}(E) \cdot f(E) d E .
$$

The respective quantities are, in sequence, the partial pressure of species $i, p_{i}$ (which is proportional to the mole fraction $x_{i}$ of that species), an instrument factor $c$, the number of sweeps $S W$, the mass discrimination factor of species $i, D_{i}$, the number of ionizing particles (photons or electrons) $\varphi$, a temperature- and thus position-dependent sampling function $F K T(h)$, the ionization cross section $\sigma_{i}(E)$ of species $i$ at energy $E$, and the energy distribution $f(E)$ of the ionizing particles. The small energy distribution of the PI-MBMS instrument makes convolution of ionization cross section and energy distribution dispensable and the direct use of tabulated photoionization cross sections applicable. The broader energy distribution of the EI-MBMS experiment is quite useful in that it provides a species overview from a single mass spectrum with high relative accuracy, since any instrumental variations will affect all species similarly. However, it makes additional evaluation steps necessary which are detailed in [17]. The procedure can be simplified by normalizing all signals by the argon signal at all energies, providing a calibration factor $k_{i}(E)$. Once this factor $k_{i}(E)$ is known for a given energy $E$, the mole fraction $x_{i}$ of an intermediate species can be calculated based on the argon mole fraction profile from the major species calculation. Depending on the applicability of cold-gas calibration (only for stable intermediates) and the availability of reliable ionization cross sections, the accuracy for stable intermediates is typically better than a factor of two, depending on their concentration levels, while for radical species, the experimental errors can be of the order of a factor three when cross sections must be estimated, see also more detailed information in [17]. 
Flame temperatures were measured as described in [17]. They were determined from the temperature dependence of the sampling rate through the probe orifice to account for sampling effects by the quartz nozzle [37]. This sampling rate is proportional, for constant pumping speed, to the pressure in the first-stage chamber [17], which was monitored in the experiment. The temperature-dependent sampling rate curves were calibrated in the burnt-gas region with laser-induced fluorescence measurements of $\mathrm{NO}$, performed in the A-X $(0-0)$ band at a wavelength of $225 \mathrm{~nm}$ (see [37] for details). The resulting temperature profiles were assumed to account for the actual probe distortion experienced in the position-dependent species composition analysis; they were used in the simulations with the flame model, and shifts between experimental and simulated mole fraction profiles were thus not applied. The accuracy of this procedure is somewhat questionable with the probe closer than about 0.3$0.5 \mathrm{~mm}$ to the burner, and regarding the combined uncertainty in the determination of the exact position for $h=0$, it is not recommended to use values at $h<0.5 \mathrm{~mm}$ in detailed species comparisons.

\section{Combustion model}

The present work is intended primarily to report a careful and comprehensive experimental analysis of the species mix encountered in the set of six flames of the smallest pair of isomeric amine fuels, ethylamine and dimethylamine. By investigating the combustion of these isomers under identical conditions, it is ascertained that differences in the species concentrations are a consequence of the respective fuel structure. Special attention is given to the formation of small nitrogenated compounds and potential variations of their concentrations with fuel and equivalence ratio, as for example ammonia, oxides of nitrogen, and hydrogen cyanide. These and other small nitrogen-containing species, however, are the result of a number of reactions in the fuel destruction and oxidation sequence, and the early 
fuel decomposition steps eventually leading to their formation are not directly evident from their measured mole fractions. As an important complement, a combustion model was thus developed and compared to the measured species profiles in a fully "blind" fashion, meaning that no attempts were made to change the model for an improved fit between experiment and simulation. For this, the thermochemistry for a number of species had to be determined from quantum chemistry calculations, and appropriate reaction subsets had to be incorporated from earlier mechanisms. The model should thus be regarded as a first, although well-founded, approximation to the amine combustion chemistry discussed here, and further development is certainly encouraged.

\subsection{Computational methodology}

The structures and vibrational frequencies (scaled by a factor of 0.99 ) of target molecules and reference species were computed via density functional theory at the B3LYP/6-311G(d,p) level of theory. The geometries are summarized in the Supplementary Material 1. Coupledcluster energies at these geometries, approximately extrapolated to the complete basis set limit in a series of additive steps, were obtained by application of the CBS-QB3 methodology of Petersson and co-workers [38]. These steps were carried out using the Gaussian 09 program [39]. With the inclusion of vibrational zero-point energy, the enthalpy changes between reactants and products at $0 \mathrm{~K}$ were derived for a series of working reactions outlined below. Heat capacities, entropies and enthalpy corrections, $\mathrm{C}_{\mathrm{P}}, \mathrm{S}$ and $\mathrm{H}_{\mathrm{T}}-\mathrm{H}_{0}$, were calculated for each species as a function of temperature $\mathrm{T}$ with the usual assumption of a rigid-rotor harmonic oscillator model, but also incorporating the algorithm of Ayala and Schlegel [40] as implemented in Gaussian 09 to account for the contributions of any free or hindered internal rotors. These data were employed to derive $\Delta_{\mathrm{r}} \mathrm{H}_{298}$ for the working reactions, where all but one of the enthalpies of formation are known. In each reaction, $\Delta_{\mathrm{f}} \mathrm{H}_{298}$ was then derived for the one unknown species, denoted with an asterisk. Initial reference species are $\mathrm{H}$ atoms and 
ethylamine. For the latter we adopted the precise value of $\Delta_{\mathrm{f}} \mathrm{H}_{298}=-11.97 \pm 0.36 \mathrm{kcal} \mathrm{mol}^{-1}$ recommended by Bodi et al. [41]. For acetonitrile we used $\Delta_{\mathrm{f}} \mathrm{H}_{298}=17.70 \pm 0.09 \mathrm{kcal} \mathrm{mol}^{-1}$ from An and Mansson [42]. As new species were determined, they were used to derive enthalpies of further species by successive H-atom eliminations:

$$
\begin{aligned}
& \mathrm{CH}_{3} \mathrm{CH}_{2} \mathrm{NH}_{2} \rightarrow \mathrm{H}+\mathrm{CH}_{2} \mathrm{CH}_{2} \mathrm{NH}_{2} \text { * } \\
& \mathrm{CH}_{3} \mathrm{CH}_{2} \mathrm{NH}_{2} \rightarrow \mathrm{H}+\mathrm{CH}_{3} \mathrm{CHNH}_{2} * \\
& \mathrm{CH}_{3} \mathrm{CH}_{2} \mathrm{NH}_{2} \rightarrow \mathrm{H}+\mathrm{CH}_{3} \mathrm{CH}_{2} \mathrm{NH}^{*} \\
& \mathrm{CH}_{3} \mathrm{CH}_{2} \mathrm{NH} \rightarrow \mathrm{H}+\mathrm{CH}_{3} \mathrm{CHNH}^{*} \\
& \mathrm{CH}_{3} \mathrm{CHNH}_{2} \rightarrow \mathrm{H}+\mathrm{CH}_{2} \mathrm{CHNH}_{2} * \\
& \mathrm{CH}_{3} \mathrm{CN}+\mathrm{H} \rightarrow \mathrm{CH}_{3} \mathrm{CHN}^{*} \\
& \mathrm{CH}_{3} \mathrm{CN}+\mathrm{H} \rightarrow \mathrm{CH}_{3} \mathrm{CNH}^{*} \\
& \mathrm{CH}_{2} \mathrm{CHNH}_{2} \rightarrow \mathrm{H}+\mathrm{CH}_{2} \mathrm{CNH}_{2} * \\
& \mathrm{CH}_{2} \mathrm{CNH}_{2} \rightarrow \mathrm{H}+\mathrm{CHCNH}_{2} * \\
& \mathrm{CHCNH}_{2} \rightarrow \mathrm{H}+\mathrm{CHCNH}^{*} \\
& \mathrm{CH}_{3} \mathrm{CNH} \rightarrow \mathrm{H}+\mathrm{CH}_{2} \mathrm{CNH}^{*}
\end{aligned}
$$

Two further molecules, with no low frequency internal torsions and therefore treated within the harmonic oscillator approximation, were evaluated relative to $\mathrm{NH}_{2}+\mathrm{C}_{2} \mathrm{H}_{2}\left(\Delta_{\mathrm{f}} \mathrm{H}_{298}=44.55\right.$ \pm 0.05 and $54.57 \pm 0.07 \mathrm{kcal} \mathrm{mol}^{-1}$, respectively, from Goos et al. [43]):

$$
\begin{aligned}
& \mathrm{NH}_{2}+\mathrm{C}_{2} \mathrm{H}_{2} \rightarrow \mathrm{CHCHNH}_{2} * \\
& \mathrm{NH}_{2}+\mathrm{C}_{2} \mathrm{H}_{2} \rightarrow \mathrm{CH}_{2} \mathrm{CHNH}^{*}
\end{aligned}
$$

The enthalpy of formation of dimethylamine was derived via the isomerization

$$
\mathrm{CH}_{3} \mathrm{CH}_{2} \mathrm{NH}_{2} \rightarrow\left(\mathrm{CH}_{3}\right)_{2} \mathrm{NH}^{*}
$$

from which other species containing the $\mathrm{C}-\mathrm{N}-\mathrm{C}$ backbone were derived:

$$
\begin{aligned}
& \left(\mathrm{CH}_{3}\right)_{2} \mathrm{NH} \rightarrow \mathrm{H}+\mathrm{CH}_{3} \mathrm{NCH}_{3} * \\
& \left(\mathrm{CH}_{3}\right)_{2} \mathrm{NH} \rightarrow \mathrm{H}+\mathrm{CH}_{3} \mathrm{NHCH}_{2} * \\
& \left(\mathrm{CH}_{3}\right)_{2} \mathrm{NH} \rightarrow \mathrm{H}_{2}+\mathrm{CH}_{3} \mathrm{NCH}_{2} *
\end{aligned}
$$




$$
\begin{aligned}
& \mathrm{CH}_{3} \mathrm{NCH}_{2} \rightarrow \mathrm{H}+\mathrm{CH}_{2} \mathrm{NCH}_{2} * \\
& \mathrm{CH}_{3} \mathrm{NCH}_{2} \rightarrow \mathrm{H}+\mathrm{CH}_{3} \mathrm{NCH}^{*}
\end{aligned}
$$

Thermochemistry of the cyclic molecule $2 \mathrm{H}$-azirine was evaluated via the working reaction

$$
\mathrm{CH}_{2} \mathrm{CHNH} \rightarrow \mathrm{H}+\mathrm{c}-\mathrm{C}_{2} \mathrm{H}_{3} \mathrm{~N}^{*}
$$

Opening of the ring leads to vinyl nitrene, whose triplet ground state was characterized via

$$
\mathrm{CH}_{2} \mathrm{CHNH} \rightarrow \mathrm{H}+\mathrm{CH}_{2} \mathrm{CHN}^{*}
$$

The low-lying singlet state is likely to be much more reactive. Its wavefunction requires multireference methods for correct analysis. Here we use an empirical approach. The heat capacity was assumed to be similar to the triplet state, and the entropy was corrected by $-\mathrm{R} \ln 3$ to account for the lack of electronic degeneracy in the singlet $\mathrm{CH}_{2} \mathrm{CHN}(\mathrm{s})$. The singlettriplet energy gap was assumed to be $15 \mathrm{kcal} \mathrm{mol}^{-1}$, similar to that in phenyl nitrene [44].

The transition states for several reactions were characterized with the same computational approach, i.e., density functional theory for the geometry and frequencies followed by CBS-QB3 theory for the energy, in order to derive the kinetics. Unimolecular rate theory was applied as implemented in the MultiWell program suite [45-47], to derive rate constants at 0.04 bar of Ar bath gas as a function of temperature. The effects of hindered rotors and quantum mechanical tunneling through an Eckart potential were included. To estimate energy transfer between Ar and reactant molecules, the exponential down model with an assumed parameter of $350 \mathrm{~cm}^{-1}$ was employed, and Lennard-Jones parameters of $\sigma=3.62$ $\AA$ and $\varepsilon / \mathrm{k}_{\mathrm{B}}=372 \mathrm{~K}$, suggested for ethylamine [48], were used for all the intermediates.

\subsection{Thermodynamic properties and kinetics for selected amine reactions}

The various $\mathrm{C}-\mathrm{H}$ and $\mathrm{N}-\mathrm{H}$ bond dissociation enthalpies we derived computationally are included in italic numbers in the proposed fuel decomposition schemes shown in Fig. 1, and the new thermochemistry is summarized in Table 2. One check on the methodology employed 
here is that the derived $\Delta_{\mathrm{f}} \mathrm{H}_{298}$ for $\left(\mathrm{CH}_{3}\right)_{2} \mathrm{NH}$ of $-4.6 \mathrm{kcal} \mathrm{mol}^{-1}$ is in excellent accord with the literature value of $-4.5 \pm 0.4 \mathrm{kcal} \mathrm{mol}^{-1}[50]$. Some especially low bond dissociation enthalpies for loss of H-atoms may be seen in Fig. 1, where the reactant is a radical and the product has a new $\pi$-bond. Examples of this kind of process include reactions 4 and 5 , where the products $\mathrm{CH}_{3} \mathrm{CHNH}$ and $\mathrm{CH}_{2} \mathrm{CHNH}_{2}$ are the imine and enamine analogs of keto/enol isomers. Acetaldehyde is about $10 \mathrm{kcal} \mathrm{mol}^{-1}$ more stable than ethenol (vinyl alcohol) [51] but the gap is smaller here, with the imine more stable than the enamine by only about $3 \mathrm{kcal} \mathrm{mol}^{-1}$. Presumably this reflects stabilization of the enamine by $\pi$-donation from the $\mathrm{NH}_{2}$ group [52]. Interconversion of these species by a 1,3 hydrogen shift is symmetry-forbidden by the Woodward-Hoffman rules and accordingly has a high barrier [52], computed here to be 80 kcal mol ${ }^{-1}$ relative to $\mathrm{CH}_{3} \mathrm{CHNH}$. An alternative pathway for interconversion could be $\mathrm{H}$ atom addition at one site followed by $\mathrm{H}$-atom loss from another. Radical intermediates from where $\mathrm{H}$-atom loss forms $\mathrm{CH}_{3} \mathrm{CN}$ yield the lowest bond dissociation enthalpies found here, of ca. $20 \mathrm{kcal} \mathrm{mol}^{-1}$, so that $\mathrm{CH}_{3} \mathrm{CHN}$ and $\mathrm{CH}_{3} \mathrm{CNH}$ are of low stability at elevated temperatures. C-N fission in the species $\mathrm{CH}_{3} \mathrm{NCH}$ to make $\mathrm{CH}_{3}+\mathrm{HCN}$ is also especially facile, driven by the stability of $\mathrm{HCN}$, with $\Delta \mathrm{H} \sim 1 \mathrm{kcal} \mathrm{mol}^{-1}$ and a barrier of $20 \mathrm{kcal} \mathrm{mol}^{-1}$. Among the dissociation products of DMA, we note that extra stability is expected for $\mathrm{CH}_{2} \mathrm{NCH}_{2}$ because it is a resonantly stabilized radical isoelectronic with allyl. The $\mathrm{CH}_{2} \mathrm{CHNH}$ and $\mathrm{CHCNH}$ radicals might also exhibit stability because they are analogous to allyl and propargyl, respectively. Two mechanisms for ring-opening of $2 \mathrm{H}$-azirine are considered here. One is that proposed by Doughty et al. [53] which proceeds via unimolecular dissociation to singlet vinyl nitrene. The second is bimolecular addition of an $\mathrm{H}$-atom at either end of the double bond to form cyclic radicals with more than enough internal energy to overcome the barriers to dissociation to $\mathrm{CH}_{2} \mathrm{NCH}_{2}$ and $\mathrm{CH}_{2} \mathrm{CHNH}$. The rate-limiting step for this mechanism is $\mathrm{H}$ addition, which was characterized via conventional transition state theory. 


\subsection{Reaction mechanism}

The modeling study for the $\mathrm{CH}_{3} \mathrm{CH}_{2} \mathrm{NH}_{2} / \mathrm{O}_{2} / \mathrm{Ar}$ and $\mathrm{CH}_{3} \mathrm{NHCH}_{3} / \mathrm{O}_{2} / \mathrm{Ar}$ flames was conducted using CHEMKIN 4.1 [54]. The starting mechanism was drawn from the recent study of $\mathrm{NH}_{3}$ doped $\mathrm{CH}_{4} / \mathrm{O}_{2} / \mathrm{Ar}$ flames [13]. This mechanism relied on work on the oxidation of $\mathrm{C}_{1} / \mathrm{C}_{2^{-}}$ hydrocarbons [55,56], $\mathrm{NH}_{3}$ [57], and $\mathrm{HCN}$ [3], as well as interactions of these components $[11,55,58,59]$. Thermal NO and prompt NO formation mechanisms $[1,60]$ are not important in the present flames due to the high concentrations of amines. The starting mechanism contained a subset for methylamine oxidation, drawn mostly from the review of Dean and Bozzelli [61]. This subset was updated with recent data on the reaction of $\mathrm{CH}_{3} \mathrm{NH}_{2}$ with $\mathrm{OH}$ $[62,63]$.

In the present work, the starting mechanism was extended to describe oxidation of $\mathrm{CH}_{3} \mathrm{CH}_{2} \mathrm{NH}_{2}$ and $\mathrm{CH}_{3} \mathrm{NHCH}_{3}$. Very little has been reported in the literature about the thermochemistry or elementary reactions of ethylamine and dimethylamine. With a few exceptions, the thermochemistry was established in the present work, as discussed above (Table 2). The full mechanism and transport data are available as Supplementary Material 2 and 3, respectively. Due to the scarcity of reliable rate constants in the literature for reactions of $\mathrm{C}_{2}$-hydrocarbon amines, these subsets had to be established from analogy with reaction sets for other species, i.e., $C_{1} / C_{2}$ hydrocarbons [56], methylamine [13,61], ethanol [64], and propane [65], or via quantum chemistry. Unfortunately, the detailed mechanisms for $\mathrm{CH}_{3} \mathrm{NH}_{2}$, $\mathrm{C}_{2} \mathrm{H}_{5} \mathrm{OH}$, and $\mathrm{C}_{3} \mathrm{H}_{8}$ contain a significant number of reactions for which no experimental data have been reported and only rough estimates or QRRK estimates are available. The uncertainty in the data for the reactions used for analogy is embedded in the present mechanism for the $\mathrm{C}_{2}$-hydrocarbon amines.

Thermal dissociation of ethylamine has at least four potential product channels:

$$
\begin{aligned}
& \mathrm{CH}_{3} \mathrm{CH}_{2} \mathrm{NH}_{2}(+\mathrm{M})=\mathrm{C}_{2} \mathrm{H}_{4}+\mathrm{NH}_{3}(+\mathrm{M}) \\
& \mathrm{CH}_{3} \mathrm{CH}_{2} \mathrm{NH}_{2}(+\mathrm{M})=\mathrm{C}_{2} \mathrm{H}_{5}+\mathrm{NH}_{2}(+\mathrm{M})
\end{aligned}
$$




$$
\begin{aligned}
& \mathrm{CH}_{3} \mathrm{CH}_{2} \mathrm{NH}_{2}(+\mathrm{M})=\mathrm{CH}_{3} \mathrm{CHNH}_{2}+\mathrm{H}(+\mathrm{M}) \\
& \mathrm{CH}_{3} \mathrm{CH}_{2} \mathrm{NH}_{2}(+\mathrm{M})=\mathrm{CH}_{2} \mathrm{CH}_{2} \mathrm{NH}_{2}+\mathrm{H}(+\mathrm{M})
\end{aligned}
$$

Here the reaction numbers refer to the listing in Appendix A, which lists the ethylamine subset, while Appendix B provides the dimethylamine subset. The rate constant $\mathrm{k}_{1}$ for (R1) was calculated via RRKM theory in the present work as described above. The value for $\mathrm{k}_{2}$ was assumed to be similar to that for the $\mathrm{CH}_{3}+\mathrm{NH}_{2}$ recombination reaction, in reasonable agreement with the room temperature measurement of $\mathrm{k}_{2}$ at $400 \mathrm{~Pa}$ by Demissy and Lesclaux [66]. $\mathrm{k}_{3}$ and $\mathrm{k}_{4}$ were estimated by analogy with the reactions $\mathrm{i}-\mathrm{C}_{3} \mathrm{H}_{7}+\mathrm{H}(+\mathrm{M})$ and $\mathrm{C}_{2} \mathrm{H}_{5}+\mathrm{H}$ (+M). For the reactions of $\mathrm{CH}_{3} \mathrm{CH}_{2} \mathrm{NH}_{2}$ with the radical pool, overall rate constants for $\mathrm{O}$ [29] and $\mathrm{OH}[62,79]$ are available. For both these steps we have assumed hydrogen abstraction from the $\alpha$-position to form $\mathrm{CH}_{3} \mathrm{CHNH}_{2}$ to be dominating, similar to what has been reported for ethanol. The channels to $\mathrm{CH}_{2} \mathrm{CH}_{2} \mathrm{NH}_{2}$ and $\mathrm{CH}_{3} \mathrm{CH}_{2} \mathrm{NH}$ are presumably minor; the rate constants for these steps, as well as those for reaction of $\mathrm{CH}_{3} \mathrm{CH}_{2} \mathrm{NH}_{2}$ with other radicals, were estimated by analogy to reactions of ethanol and methylamine. Available data for reactions with $\mathrm{O}$ and $\mathrm{OH}$ indicate that hydrogen abstraction from ethylamine is faster than from methyl amine and ethanol, respectively, but slower than for dimethylamine.

The hydrogen abstraction reactions from $\mathrm{CH}_{3} \mathrm{CH}_{2} \mathrm{NH}_{2}$ yield the three isomeric radicals $\mathrm{CH}_{2} \mathrm{CH}_{2} \mathrm{NH}_{2}, \mathrm{CH}_{3} \mathrm{CHNH}_{2}$, and $\mathrm{CH}_{3} \mathrm{CH}_{2} \mathrm{NH}$. Dissociation of these radicals by breaking either the $\mathrm{C}-\mathrm{C}$ or $\mathrm{C}-\mathrm{N}$ bond feeds into the $\mathrm{C}_{1} / \mathrm{C}_{2}$-hydrocarbon pool and small amines. Information on dissociation of $\mathrm{CH}_{2} \mathrm{CH}_{2} \mathrm{NH}_{2}$ to form $\mathrm{C}_{2} \mathrm{H}_{4}$ and $\mathrm{NH}_{2}$ (R22b) can be obtained from studies of the reverse step. At low temperatures the reaction between $\mathrm{NH}_{2}$ and $\mathrm{C}_{2} \mathrm{H}_{4}$ forms an adduct, while at higher temperatures $\mathrm{H}$-abstraction becomes dominating, There is significant scatter in the reported low-temperature data $[67,80,81]$; we have adopted the rate constant determined by Khe and Lesclaux [67]. It should be noted that (R22) is likely to be in the fall-off region at the temperature and pressure range of the present study, and the chosen rate constant may not extrapolate well to these conditions. Dissociation of $\mathrm{CH}_{3} \mathrm{CHNH}_{2}$ is expected to yield either 
$\mathrm{CH}_{2} \mathrm{CHNH}_{2}+\mathrm{H}(\mathrm{R} 30 \mathrm{~b})$ or $\mathrm{CH}_{3} \mathrm{CHNH}+\mathrm{H}(\mathrm{R} 31)$, while dissociation of $\mathrm{CH}_{3} \mathrm{CH}_{2} \mathrm{NH}$ in addition to $\mathrm{CH}_{3} \mathrm{CHNH}+\mathrm{H}(\mathrm{R} 43)$ may yield $\mathrm{CH}_{3}$ and $\mathrm{CH}_{2} \mathrm{NH}$ (R42). In the absence of experimental data, the rate constant for (R42) was estimated by analogy to the dissociation of $\mathrm{CH}_{3} \mathrm{CH}_{2} \mathrm{O}$ at low pressure. Other steps of the three isomeric radicals are mostly comparatively fast radical-radical reactions, most of which involve hydrogen abstraction. Abstraction of $\mathrm{H}$ from $\mathrm{CH}_{2} \mathrm{CH}_{2} \mathrm{NH}_{2}$ and $\mathrm{CH}_{3} \mathrm{CHNH}_{2}$ leads to $\mathrm{CH}_{2} \mathrm{CHNH}_{2}$, while $\mathrm{CH}_{3} \mathrm{CH}_{2} \mathrm{NH}$ yields $\mathrm{CH}_{3} \mathrm{CHNH}$. However, by analogy with reactions of iso-electronic species such as the propyl isomers and $\mathrm{CH}_{3} \mathrm{CHOH}$, we expect a number of the $\mathrm{C}_{2} \mathrm{H}_{6} \mathrm{~N}+$ radical reactions to involve breaking of the C-C or C-N bond, most pronounced for $\mathrm{CH}_{3} \mathrm{CHNH}_{2}$.

Both $\mathrm{CH}_{2} \mathrm{CHNH}_{2}$ and $\mathrm{CH}_{3} \mathrm{CHNH}$ are stable molecules. $\mathrm{CH}_{2} \mathrm{CHNH}_{2}$ is mainly consumed by reaction with the radical pool. For $\mathrm{CH}_{2} \mathrm{CHNH}_{2}, \mathrm{H}$-abstraction from the $\mathrm{C}$-atoms was assumed to be similar to that for $\mathrm{C}_{2} \mathrm{H}_{4}$, while breaking of the $\mathrm{N}-\mathrm{H}$ bond was estimated by analogy with that for $\mathrm{CH}_{3} \mathrm{NH}_{2}$. Rate constants for $\mathrm{CH}_{3} \mathrm{CHNH}$ reactions were estimated by analogy with reactions of $\mathrm{CH}_{3} \mathrm{HCO}$ and $\mathrm{CH}_{2} \mathrm{NH}$. For $\mathrm{CH}_{3} \mathrm{CHNH}$, thermal dissociation to form $\mathrm{HCNH}+\mathrm{CH}_{3}(\mathrm{R} 65 \mathrm{~b})$ may become important at higher temperatures. Isomerization between $\mathrm{CH}_{2} \mathrm{CHNH}_{2}$ and $\mathrm{CH}_{3} \mathrm{CHNH}$ (R66) is at most a minor pathway due to a high activation energy, as discussed above.

Hydrogen abstraction from $\mathrm{CH}_{2} \mathrm{CHNH}_{2}$ and $\mathrm{CH}_{3} \mathrm{CHNH}$ yields a range of $\mathrm{C}_{2} \mathrm{H}_{4} \mathrm{~N}$ radicals, i.e. $\mathrm{CHCHNH}_{2}, \mathrm{CH}_{2} \mathrm{CNH}_{2}, \mathrm{CH}_{2} \mathrm{CHNH}, \mathrm{CH}_{3} \mathrm{CNH}$, and $\mathrm{CH}_{3} \mathrm{CHN}$. The $\mathrm{CHCHNH}_{2}$ radical dissociates fairly easily to form $\mathrm{C}_{2} \mathrm{H}_{2}+\mathrm{NH}_{2}$ (R82b); the reverse step (addition) has been characterized by Moskaleva and Lin [68]. The reactivity of $\mathrm{CH}_{2} \mathrm{CNH}_{2}$ could be expected to be similar to that of $\mathrm{C}_{2} \mathrm{H}_{3}$, yielding $\mathrm{CHCNH}_{2}$ as well as oxygenated intermediates. $\mathrm{CH}_{2} \mathrm{CHNH}$ is a resonantly stabilized radical, similar to $\mathrm{CH}_{2} \mathrm{CHO}$, and rate constants have been estimated by analogy with this species. $\mathrm{CH}_{3} \mathrm{CNH}$ and $\mathrm{CH}_{3} \mathrm{CHN}$ are expected to decompose easily into the cyanide pool, forming either $\mathrm{HCN} / \mathrm{HNC}+\mathrm{CH}_{3}$ or $\mathrm{CH}_{3} \mathrm{CN}+\mathrm{H}$. Of the remaining $\mathrm{C}_{2}$-amines, only the reactions of $\mathrm{CH}_{3} \mathrm{CN}$ are comparatively well established. 
Reactions of $\mathrm{CHCNH}_{2}$ and the derived radical $\mathrm{CHCNH}$ are uncertain, but these species are of minor importance in the present flames.

Special attention was paid to the chemistry of the cyclic species $2 \mathrm{H}$-azirine $\left(\mathrm{c}-\mathrm{C}_{2} \mathrm{H}_{3} \mathrm{~N}\right)$, a three-membered ring. The key reactions for this species were characterized from ab initio theory, as discussed above. The ring species could be formed by cyclization of $\mathrm{CH}_{2} \mathrm{CHNH}$ and subsequent $\mathrm{H}$-atom loss (R154b). A favorable path for $2 \mathrm{H}$-azirine decomposition is via a nitrene intermediate, $\mathrm{CH}_{2} \mathrm{CHN}$, which in turn can isomerize to acetonitrile. Another possibility is the ring-opening isomerization to acetonitrile (R152), as proposed by Tian et al. [15], and as discussed above.

The nitrene $\mathrm{CH}_{2} \mathrm{CHN}$ is analogue to a carbene, e.g., methylene, and similarly to methylene, the ground state triplet and excited state singlet are sufficiently close in energy that both need to be taken into account. It can be formed by hydrogen abstraction from $\mathrm{CH}_{3} \mathrm{CHN}$ (R116-117, R120-121). The nitrene reactions, including intersystem crossing between the two states, are estimated from analogy with $\mathrm{CH}_{2}(\mathrm{R} 143-151)$. The bimolecular reactions of singlet $\mathrm{CH}_{2} \mathrm{CHN}$ are presumably fast. Still, they may not be able to compete with unimolecular isomerization to $\mathrm{CH}_{3} \mathrm{CN}$ (R148), which has a low barrier of about $8 \mathrm{kcal} \mathrm{mol}^{-1}$.

The subset for $\mathrm{CH}_{3} \mathrm{NHCH}_{3}$ (Appendix B) is simpler than that for $\mathrm{CH}_{3} \mathrm{CH}_{2} \mathrm{NH}_{2}$ in that it involves fewer species and reactions. Dimethylamine is mainly consumed by reaction with the radical pool. The overall reactions with O (R192, R193) and OH (R194, R195) have been characterized experimentally [29,62,79]; the branching fractions to $\mathrm{CH}_{3} \mathrm{NHCH}_{2}$ and $\mathrm{CH}_{3} \mathrm{NCH}_{3}$ were estimated $\left(\mathrm{CH}_{3} \mathrm{NHCH}_{3}+\mathrm{O}\right)$ or drawn from theoretical work [63] $\left(\mathrm{CH}_{3} \mathrm{NHCH}_{3}+\mathrm{OH}\right)$. Other reactions of $\mathrm{CH}_{3} \mathrm{NHCH}_{3}$ with the radical pool were assumed to be similar to those of $\mathrm{CH}_{3} \mathrm{NH}_{2}$; judging from the diethylamine $+\mathrm{O} / \mathrm{OH}$ reactions, the dimethylamine steps would be expected to be somewhat faster than the corresponding methylamine steps. The fuel-derived radicals $\mathrm{CH}_{3} \mathrm{NHCH}_{2}$ and $\mathrm{CH}_{3} \mathrm{NCH}_{3}$ may dissociate to form either $\mathrm{CH}_{3} \mathrm{NCH}_{2}+\mathrm{H}(\mathrm{R} 201, \mathrm{R} 209)$ or $\mathrm{CH}_{3}+\mathrm{CH}_{2} \mathrm{NH}$ (R200); the rate coefficients for 
these steps were calculated in the present work as discussed above. Radical abstraction reactions of $\mathrm{CH}_{3} \mathrm{NHCH}_{2}$ and $\mathrm{CH}_{3} \mathrm{NCH}_{3}$ to form $\mathrm{CH}_{3} \mathrm{NCH}_{2}$ are not well known, but can be assumed to be fairly fast.

The stable species $\mathrm{CH}_{3} \mathrm{NCH}_{2}$ reacts mainly with radicals to form either $\mathrm{CH}_{2} \mathrm{NCH}_{2}$ or $\mathrm{CH}_{3} \mathrm{NCH}$. Little is known about these steps, but they are presumably similar to reactions of $\mathrm{C}_{1}$-hydrocarbon amines. Isomerization of $\mathrm{CH}_{2} \mathrm{NCH}_{2}$ to $\mathrm{CH}_{3} \mathrm{NCH}$ (R226) was calculated in the present work, but constitutes only a minor pathway. Also cyclization followed by H-atom elimination to form $2 \mathrm{H}$-azirine (R153b) is at most a minor pathway. Reactions of $\mathrm{CH}_{2} \mathrm{NCH}_{2}$ and $\mathrm{CH}_{3} \mathrm{NCH}$ feed into the cyanide pool; $\mathrm{CH}_{2} \mathrm{NCH}_{2}$ is expected to react with $\mathrm{O} / \mathrm{H}$ radicals to yield $\mathrm{H}_{2} \mathrm{CN}$, while $\mathrm{CH}_{3} \mathrm{NCH}$ dissociates rapidly to form $\mathrm{HCN}$ (R230).

\section{Results and discussion}

To facilitate the analysis of the detailed reaction sequences for the two fuels, Fig. 1 combines the information on the first stages of fuel destruction, as was in part already discussed above for the mechanism development. These reaction sequences are thus not mainly devoted to represent the kinetic mechanism, but to rationalize specific groups of intermediates that can be compared with the experiment, where the EI-MBMS results first provide detection at a given exact mass (mass-to-charge ratio $\mathrm{m} / \mathrm{z}$, with the assumption of singly charged ions). These $\mathrm{C}_{\mathrm{n}} \mathrm{H}_{\mathrm{m}} \mathrm{N}$ signals each can represent several isomers, and depending on their respective mole fractions and available information on their ionization energies and cross sections, these may be separated and quantified in part using PI-MBMS. The $m / z$ ratios are indicated for each species to facilitate comparison with some of the mole fraction profiles detected at a specific mass given below, which sometimes represent the respective sums of isomers.

The sequences in the two schemes show in the first step the products of $\mathrm{H}$-abstraction from the fuel to form initial radicals with sum formula $\mathrm{C}_{2} \mathrm{H}_{6} \mathrm{~N}$ (at mass 44), yielding three 
isomeric radicals for EA, and two for DMA. This is followed by formation of a stable unsaturated molecule $\left(\mathrm{C}_{2} \mathrm{H}_{5} \mathrm{~N}\right.$ at mass 43$)$ or by $\beta$-scission, with stable and radical scission products including $\mathrm{CH}_{3}$ and $\mathrm{H}_{2} \mathrm{C}=\mathrm{NH}$, as well as $\mathrm{C}_{2} \mathrm{H}_{4}$ and $\mathrm{NH}_{2}$. Such combinations of $\mathrm{H}-$ abstraction and $\beta$-scission have been also found helpful in the fuel decomposition for morpholine combustion [17,82]. All species highlighted with grey shading were detected in the experiment. The $\mathrm{H}$-abstraction and $\beta$-scission principle is then continued to include potential nitrogenated intermediates of the compositions $\mathrm{C}_{2} \mathrm{H}_{4} \mathrm{~N}$ and $\mathrm{C}_{2} \mathrm{H}_{3} \mathrm{~N}$ at mass 42 and 41, respectively. Of the conceived products, several were detected, including acetylene, cyanic acid and acetonitrile from EA combustion. Interestingly, as a $\mathrm{C}_{2} \mathrm{H}_{3} \mathrm{~N}$ species, $2 \mathrm{H}-$ azirine was identified, while ketenimine was below the detection limit. With these considerations, species information will be discussed, first for major products, then for nitrogenated intermediates, in sequence of the fuel decomposition, with some further hydrocarbon and oxygenated buildup products briefly highlighted at the end.

\subsection{Major species}

The overall flame structure for the two fuels is given in Figs. 2 and 3, which show the major species profiles, the temperature profiles, and the equilibrium mole fractions of all flames investigated in this work. The flame pairs of EA and DMA show only minor differences in the species spectrum observed at the same stoichiometry, and the exhaust mole fractions match the equilibrium values quite well. Peak temperatures are near $2000 \mathrm{~K}$ for all six flames, with some variation for the different equivalence ratios. This variation is largest for the EA flame where peak temperatures are almost $500 \mathrm{~K}$ higher in the fuel-rich than in the lean flame, while differences are less pronounced for the DMA flames. The absolute temperature uncertainty is typically below $100 \mathrm{~K}$. Temperature may influence the $\mathrm{NO}_{\mathrm{x}}$ formation considerably [1], but less so for the fuel-NO mechanism (as in this work) than for thermal NO. 
Although NO is included in Figs. 2 and 3, because it is attains mole fractions of a few percent and represents thus a non-negligible product, concentration differences are not obvious. The mole fraction profiles of NO for all six flames are thus included in Fig. 4 which presents in addition the predictions of $\mathrm{N}_{2}$ and $\mathrm{NO}$ by the model for the two stoichiometric flames. All NO profiles in Fig. 4a show a slight decay towards the burnt gas but remain at levels of $1-4 \%$, likely to be found in combustion exhaust when burning these amines. This is of similar magnitude as for the $\Phi=1.3$ morpholine flame [17], with an NO mole fraction in the burnt gases of about 0.02 , well-predicted by the respective model, with the consideration, however, of a twofold higher N/C ratio in the amine fuels here. For the ammonia-blended methane flame in [13] with an $\mathrm{NH}_{3} / \mathrm{CH}_{4}$ ratio of 0.5 , the $\mathrm{NO}$ mole fraction is also near $2 \%$ and persists well into the burnt gas. The differences in NO are negligible for the fuel-rich EA and DMA flames, where intermediate-type profiles are observed, and where some reburning reactions might consume NO, regarding the higher amounts of small hydrocarbon species under fuel-rich conditions. In the stoichiometric flames, the secondary amine DMA gives apparently rise to about $25 \%$ higher NO levels, a tendency which is more pronounced for the two lean flames where the NO peak mole fractions differ by about a factor of two. This may be owed in part to a temperature effect.

It is thus instructive to compare experiment and model predictions for $\mathrm{N}_{2}$ and $\mathrm{NO}$, which is done for the stoichiometric EA and DMA flames in Fig. $4 \mathrm{~b}$ and 4c, respectively. In general the fuel-lean and stoichiometric flames show an NO mole fraction significantly higher than the equilibrium values. The simulations with the flame model are found in very good agreement for both $\mathrm{N}_{2}$ and $\mathrm{NO}$, with a ratio of $\mathrm{NO} / \mathrm{N}_{2}$ of $\sim 0.7$ for EA and $\sim 1$ for DMA.

\subsection{Nitrogenated fuel decomposition products and intermediates}

Following the schemes in Fig. 1, the nitrogenated intermediates are presented in sequence, approximately from higher to lower mass, as they have been detected in the experiments. For 
this, mole fraction profiles are reported primarily from the EI-MBMS experiments, if not indicated otherwise. The respective figures are organized to show the quantitative profiles of the three stoichiometry pairs, always for EA on the left, and DMA on the right-hand side. Mole fractions are typically reported in units of $10^{-3}$, with scales chosen to facilitate comparison. The top curves from the experiments are complemented with the simulated ones from the model calculation, mirrored to enable comparison of the overall profile shapes. In light of the explorative nature of the mechanism we have chosen this presentation which enables to compare global trends. Note that quantitative values may be different, evident from the respective axes, which have again been chosen to provide easy conversion between experiment and simulation. For all six flames, a list of detected intermediate species, their maximum mole fractions, and the positions of these maxima from experiment and simulation is given in Table 3 for ethylamine combustion, and in Table 4 for dimethylamine combustion. Ionization energies for the detection of these species are included, and identification and quantification was performed using information from the NIST database [51] and following procedures described in detail for the previously studied morpholine flame [17,82]. For some species detected here, ionization energies have been calculated in addition from quantum chemistry, and they are included in the Supplementary Material 4. For quantification of some of these compounds, cross sections would, however, be needed in addition.

\subsubsection{Intermediates of composition $\mathrm{C}_{2} \mathrm{H}_{6} \mathrm{~N}$}

The mole fraction profiles of the detected species of sum formula $\mathrm{C}_{2} \mathrm{H}_{6} \mathrm{~N}$ are presented in Fig. 5. Detection of specific isomers (compare Fig. 1) was not possible, because no clear onsets were detected in the photoionization efficiency (PIE) curves measured in the PI-MBMS experiment. This precluded their assignment in spite of newly calculated ionization energies; also cross sections for their quantitative detection are lacking. The shapes of the profiles from the experiment resemble those of the fuel. With EA as the fuel, highest values are found in the 
stoichiometric flame, and in the DMA flames, the mole fractions are about an order of magnitude higher and increase with equivalence ratio. The comparison with the sum of species of composition $\mathrm{C}_{2} \mathrm{H}_{6} \mathrm{~N}$ predicted by the model presents some similarities and differences. As seen in the experiment, the model also predicts higher absolute values for the DMA flames, but only by a factor of about 3-4, and accordingly, maximum mole fractions are under-predicted by factors of $\sim 3$ and $\sim 6$ in the EA and DMA flames, respectively. The predicted shapes change with fuel and stoichiometry. As in the experiment, they start also quite close to the burner, but their increase at low height shows more intermediate-type behavior, potentially hinting at some contribution from fragmentation of the fuel in the experiment. Simulated maximum mole fractions are almost independent of stoichiometry for both EA and DMA. Trends in the DMA flames in the sequence of maxima and decay of $\mathrm{C}_{2} \mathrm{H}_{6} \mathrm{~N}$ species are similar in experiment and model, where they are formed and consumed earliest in the lean flame and persist longest in the slightly rich flame. Comparing the temperature and major species profiles in Fig. 3, it seems unlikely that this is a mere effect of temperature or stand-off distance of the flame.

It is interesting to analyze the contributions of the individual $\mathrm{C}_{2} \mathrm{H}_{6} \mathrm{~N}$ radicals in the model. These are presented for the two stoichiometric flames in the bottom panels of Fig. 5 . Also included is the experimental curve for this pair at $\Phi=1.0$ from the top panels (labeled "high") which was corrected for fragmentation in the usual way from calibration measurements. This correction is quite important, with fuel $\left(\mathrm{C}_{2} \mathrm{H}_{7} \mathrm{~N}\right)$ being the likely precursor which is present in large concentrations and exhibits a low ionization threshold. Because of the fuel-type shape of the experimental profiles, the largest reasonable fragmentation correction consistent with the measurements was applied, resulting in the mole fractions for $\mathrm{C}_{2} \mathrm{H}_{6} \mathrm{~N}$ labeled "low" and represented by the open symbols. It is evident that the mole fractions decrease slightly, with no significant change in the profile shapes, however. The model shows that $\mathrm{CH}_{3} \mathrm{CH}_{2} \mathrm{NH}$ is formed earliest in the EA flame and $\mathrm{CH}_{3} \mathrm{NHCH}_{2}$ in the 
DMA flame. The dominant isomer for EA is $\mathrm{CH}_{3} \mathrm{CHNH}_{2}$, corresponding to the lowest bond dissociation energy (see Fig. 1), and in the dimethylamine flame, $\mathrm{CH}_{3} \mathrm{NCH}_{3}$ is the radical attaining highest mole fraction.

\subsubsection{Intermediates of composition $\mathrm{C}_{2} \mathrm{H}_{5} \mathrm{~N}$}

The species with the composition $\mathrm{C}_{2} \mathrm{H}_{5} \mathrm{~N}$ were detected as the sum of isomers by EI-MBMS, and they are represented as these sums with maximum mole fractions provided in Tables 3 and 4 and profiles shown in Fig. 6. The assignment of isomers was derived from PI-MBMS measurements in the fuel-rich flames. For the ethylamine flame, both acetaldimine, $\mathrm{CH}_{3} \mathrm{CH}=\mathrm{NH}$, and ethenamine, $\mathrm{CH}_{2}=\mathrm{CHNH}_{2}$, contribute, with acetaldimine representing the larger fraction (see Table 3). In the DMA13 flame, the signal was almost entirely assigned to $\mathrm{N}$-methylmethanimine, $\mathrm{CH}_{3} \mathrm{~N}=\mathrm{CH}_{2}$. Here, it was not possible to determine the contribution of acetaldimine, but the very low mole fraction of ethenamine (see Table 4) gives an indication that the isomers with a two-carbon chain do not make a substantial contribution for DMA, in full accord with the decomposition schemes in Fig. 1.

The simulation in Fig. 6 provides quite realistic shapes of the mole fraction profiles for the EA flames, and they also agree with the experiments in that the trends with stoichiometry are not pronounced. Further, the quantitative agreement is very good for the sums of isomers, however with ethenamine being the dominant species in the model for all three stoichiometries, in contrast to the experiment. In the DMA flames, some global trends are also similar between experiment and model. The sequence of maxima, with the latest peak in the fuel-rich flame, is quite well reproduced. Similarly to the PI-MBMS experiment in the fuelrich flame, the model reflects $\mathrm{C}_{2} \mathrm{H}_{5} \mathrm{~N}$ to be predominantly $\mathrm{CH}_{3} \mathrm{~N}=\mathrm{CH}_{2}$ for the three stoichiometries. The quantitative agreement between the PI-MBMS experiment and the model for this species is quite good for the DMA13 flame, where also the partition between the detected isomers as well as the detected sum of isomers from the EI-MBMS measurement 
show a reasonably good match with the simulation. The experiment shows an increase of $\mathrm{C}_{2} \mathrm{H}_{5} \mathrm{~N}$ towards the stoichiometric and lean DMA flames by factors of 2-3, whereas the model reflects a relatively constant mole fraction of the $\mathrm{C}_{2} \mathrm{H}_{5} \mathrm{~N}$ sum - predominantly $\mathrm{CH}_{3} \mathrm{~N}=\mathrm{CH}_{2}$ as the most abundant isomer - with stoichiometry.

The origin of these observed differences is probably not only a function of $\mathrm{C}_{2} \mathrm{H}_{5} \mathrm{~N}$ consumption reactions in the model, especially not in the DMA flames where the sequence of peaks and the decay are quite well captured, and where essentially only a single isomer is involved. A higher peak mole fraction could potentially be attained by the model with slower $\mathrm{CH}_{3} \mathrm{~N}=\mathrm{CH}_{2}$ consumption reactions, but this would probably alter the profile shapes unsatisfactorily. It seems more likely that the observed experimental behavior is already carried over from $\mathrm{C}_{2} \mathrm{H}_{6} \mathrm{~N}$ as the respective precursor species, where a similar sequence of maxima and a trend of larger mole fractions for the lean and stoichiometric DMA flames were also observed in the experiment (see Fig. 5). Both $\mathrm{C}_{2} \mathrm{H}_{6} \mathrm{~N}$ isomers from DMA may form $\mathrm{CH}_{3} \mathrm{~N}=\mathrm{CH}_{2}$, but it seems from Fig. 5 that the mole fraction profile for $\mathrm{CH}_{3} \mathrm{NCH}_{3}$ as the dominant contribution lags a bit behind the experimental profile for the $\mathrm{C}_{2} \mathrm{H}_{6} \mathrm{~N}$ sum, whereas $\mathrm{CH}_{3} \mathrm{NHCH}_{2}$ is formed quite early. Possibly, the balance of formation and consumption of these isomers could influence the contribution towards $\mathrm{C}_{2} \mathrm{H}_{5} \mathrm{~N}$. This balance between the formation and consumption reactions may be more complex in the ethylamine flames where both dominant $\mathrm{C}_{2} \mathrm{H}_{6} \mathrm{~N}$ isomers can feed into the production of both ethenamine and acetaldimine, and more detailed analysis might be needed to explain the inverse importance of acetaldimine as the dominant isomer in the experiment, at least in the fuel-rich flame, and ethenamine as the dominant isomer in the model.

It may be interesting to compare the abundance of this pair of isomers in the previously investigated fuel-rich morpholine flame [17] under similar conditions. Here again, the PIMBMS experiment shows the larger mole fraction for acetaldimine, which exceeds that of ethenamine by more than a factor of 10 . The completely independent model in that paper did 
not differentiate between both isomers, however. Analogous considerations regard the tautomeric pair of ethenol and acetaldehyde. In the morpholine flame, the latter was also seen to dominate in the PI-MBMS experiment, with the isomer sum from the EI-MBMS experiment - interpreted as acetaldehyde - in reasonable agreement, as well as with the model which considered only acetaldehyde [17]. A closer structural analogy to the present case of EA and DMA combustion and the formation of ethenamine versus acetaldimine might be ethanol and dimethylether (DME) combustion and ethenol versus acetaldehyde formation. Fuel-rich low-pressure flames of both oxygenated isomers have been studied experimentally under quite similar conditions [34-36]. Wang et al. [36] determined maximum mole fractions of acetaldehyde of $2.9 \times 10^{-3}$ in a low-pressure DME flame where no ethenol mole fraction was reported, and $1.6 \times 10^{-2}$ of acetaldehyde in the corresponding identical ethanol flame, where the ethenol mole fraction peaked at $1.2 \times 10^{-3}$ (see Supporting Information of [36].) A recent study by Frassoldati et al. [83] that modeled the full set of flames from [36] has only discussed acetaldehyde in their simulation. However, the experiments suggest that also in these analogue low-pressure premixed oxygenated-fuel flames, the aldehyde mole fraction exceeds that of the enol, similarly as found here for the corresponding imine-enamine pair. The different importance observed in the model for ethenamine in the EA flames may thus need further investigation.

\subsubsection{Intermediates of composition $\mathrm{C}_{2} \mathrm{H}_{4} \mathrm{~N}$}

The mole fraction profiles of the $\mathrm{C}_{2} \mathrm{H}_{4} \mathrm{~N}$ species at $m / z=42$ are shown in Fig. 7. The measured signals were again affected by some fragmentation from the $\mathrm{C}_{2} \mathrm{H}_{6} \mathrm{~N}$ species, i.e. the radicals produced from $\mathrm{H}$-abstraction from the fuel. Again, the usual fragmentation correction providing the curves marked as "high" is compared with the maximum reasonable fragmentation yielding the curves labeled as "low" - both sets are given in the bottom panels for the stoichiometric flames. The profile in the EA flame changes noticeably with the strong 
fragmentation correction, with a more intermediate-shaped profile as the result. Similarly, the early onset in the EA08 and the EA13 flames could be, at least in part, due to fragmentation. According to the schemes in Fig. 1, several structures of sum formula $\mathrm{C}_{2} \mathrm{H}_{4} \mathrm{~N}$ are conceivable in the fuel decomposition, with five species featuring a CCN chain in the EA flames and two with a $\mathrm{CNC}$ sequence in the DMA flames. For EA decomposition, $\mathrm{CH}_{2} \mathrm{CH}=\mathrm{NH}$ could be formed via several pathways, and the other isomers are derived either from the acetaldimine or the enamine. For DMA, both isomers should stem from the $\mathrm{N}$-methylmethanimine with a potential to interconversion. The measured mole fractions are all of order $10^{-3}$ in the six investigated flames, with some subtle differences, however. The sum mole fraction of $\mathrm{C}_{2} \mathrm{H}_{4} \mathrm{~N}$ species increases with increasing equivalence ratio in the EA flames while the opposite trend is noted in the DMA flames. For both fuels, the peak mole fractions remain almost constant with stoichiometry in the simulations. Consistently, the maxima show a shift towards later times with increasing $\Phi$, with the stronger tendency observed in the DMA flames, consistent with the behavior discussed earlier for the $\mathrm{C}_{2} \mathrm{H}_{5} \mathrm{~N}$ and $\mathrm{C}_{2} \mathrm{H}_{6} \mathrm{~N}$ precursors.

\subsubsection{Intermediates of composition $\mathrm{C}_{2} \mathrm{H}_{3} \mathrm{~N}$}

Continuing in the sequence of fuel decomposition, Fig. 8 presents the mole fraction profiles of the species with the composition $\mathrm{C}_{2} \mathrm{H}_{3} \mathrm{~N}$ at $m / z=41$. Peak mole fractions measured as the sum of all isomers by EI-MBMS are of the order of $10^{-2}$ in the EA flames and $2-5 \times 10^{-3}$ in the DMA flames. With the PI-MBMS experiment in the fuel-rich flame, it was possible to identify acetonitrile, $\mathrm{CH}_{3} \mathrm{CN}$, at $12.2 \mathrm{eV}$, as well as the cyclic compound $2 \mathrm{H}$-azirine at 10.5 $\mathrm{eV}$ in both set of flames, see the PIE spectra in Fig. 9. This latter species had been identified experimentally in previous work [15,17,82]; also, it was noted before [17] that ketenimine, $\mathrm{CH}_{2}=\mathrm{C}=\mathrm{NH}$ was not detected at $9.3 \mathrm{eV}$ in the morpholine flame, and it was not seen here either within the sensitivity of the PI-MBMS experiment. From the decomposition schemes in Fig. 1, acetonitrile is expected in the EA flames. Pathways forming and consuming $2 \mathrm{H}$-azirine 
are also shown in Fig. 1 as included in the model. The model results for $\mathrm{C}_{2} \mathrm{H}_{3} \mathrm{~N}$ species in Fig. 8 are given for acetonitrile as the only isomer that shows a notable mole fraction in the simulation. Trends regarding the profile shapes and the stoichiometry dependence are quite comparable between experiment and model, with huge differences in the absolute mole fractions, however.

The analysis for the $\mathrm{C}_{2} \mathrm{H}_{3} \mathrm{~N}$ isomers is presented in more detail for the fuel-rich flames in Fig. 10. From the combination of the EI-MBMS and PI-MBMS experiments, good agreement is seen between the sum of $\mathrm{C}_{2} \mathrm{H}_{3} \mathrm{~N}$ species mole fractions with that of $\mathrm{CH}_{3} \mathrm{CN}$ as the dominant isomer. The mole fraction of $\mathrm{CH}_{3} \mathrm{CN}$ is about a factor of three higher in the EA13 flame where a direct pathway is available (see Fig. 1) than in the DMA13 flame. Mole fractions of $2 \mathrm{H}$-azirine from the experiment are about one (DMA13) and two (EA13) orders of magnitude lower than for $\mathrm{CH}_{3} \mathrm{CN}$, respectively, with small mole fractions not unexpected from the rather low onset in Fig. 9. The simulation provides acetonitrile and $2 \mathrm{H}$-azirine for both fuel-rich flames. Peak values are much below those of the experiment with the ratio between both isomers also different between the two flames.

The mole fraction of the toxic intermediate acetonitrile is substantially underpredicted. One reason may be that the ratio between the formation of the $\mathrm{C}_{2} \mathrm{H}_{5} \mathrm{~N}$ isomers acetaldimine and ethenamine, at least in the EA flames, also deviates from the experiment. According to the sequence of intermediates in Fig. 1, isomers of the composition $\mathrm{C}_{2} \mathrm{H}_{3} \mathrm{~N}$ are available through several pathways, with acetonitrile resulting from acetaldimine which was under-predicted in the model. The scheme in Fig. 1 also suggests the likely formation of ketenimine. Potentially, ketenimine is rapidly decomposed, resulting in a mole fraction of below the detection limit, or isomerization to the most stable isomer acetonitrile may take place. In the DMA flames, nearly all pathway lead to $\mathrm{HCN}$ as product. It is not seen on first glance how different $\mathrm{C}_{2} \mathrm{H}_{3} \mathrm{~N}$ isomers would be formed, although acetonitrile and $2 \mathrm{H}$-azirine are also clearly evident from Fig. 9. One possible path could be the isomerization under H- 
atom loss from the mesomer-stabilized radical $\mathrm{CH}_{2}-\mathrm{N}=\mathrm{CH}_{2} \bullet$ to compounds with the sum formula $\mathrm{C}_{2} \mathrm{H}_{3} \mathrm{~N}$.

\subsubsection{Further small nitrogenated species}

Methanimine, $\mathrm{CH}_{2} \mathrm{NH}$, and species with the composition $\mathrm{CH}_{2} \mathrm{~N}$ are shown in Fig. 11. Isomerspecific assignments of the latter was not feasible because of ambiguous onsets in the PIE curve and lacking reference values for the $\mathrm{HCNH}$ isomer. Methanimine is easily rationalized as a decomposition product for both fuels (compare Fig. 1). Peak mole fractions are of the order of $3-5 \times 10^{-3}$ in all six flames. The simulation agrees quite well, especially in the EA flames, both in the shapes of the mole fraction profiles and in absolute values. The sequence of maxima with a later peak in the fuel-rich DMA flames is consistent between experiment and model, and it is in accord with the similar sequence seen for the precursor species $\mathrm{C}_{2} \mathrm{H}_{6} \mathrm{~N}$ in Fig. 5. Some differences regard the stoichiometry dependence and slight over-prediction in the DMA flames. For $\mathrm{CH}_{2} \mathrm{~N}$ species, the measured mole fractions from the EI-MBMS experiment are compared with the sum of $\mathrm{H}_{2} \mathrm{CN}$ and $\mathrm{HCNH}$ from the simulations in the lower panels of Fig. 11. The agreement of the profile shapes is not completely unreasonable; however, absolute values from the model are much below those of the experiment. Such discrepancies might not be surprising for species which are a product of a considerable number of precursor reactions which are not all known in sufficient detail.

\subsection{6 $\mathrm{NH}_{3}$ and $\mathrm{HCN}$}

Figure 12 presents the mole fraction profiles of $\mathrm{HCN}$ and $\mathrm{NH}_{3}$ as those of the most important small nitrogenated species. Here, significant differences are seen for the ammonia profiles. In the EA flames, peak mole fractions depend noticeably on stoichiometry, with highest values of about $1.5 \%$ in the fuel-rich flames. According to the reaction sequences in Fig. $1, \mathrm{NH}_{\mathrm{i}}$ species, especially $\mathrm{NH}_{2}$, are formed in initial steps of the fuel decomposition for EA, while 
this is not the case for DMA as a fuel, where ammonia must be built up through different reactions. In the DMA flames, the resulting mole fractions are an order of magnitude smaller, with only a moderate stoichiometry dependence. The simulation is very consistent with the trends from the experiment in shape, location, and sequence as well as stoichiometry dependence of the maxima; also, the higher mole fractions in the EA flames are well predicted, although a tendency is noted to under-predict $\mathrm{NH}_{3}$ in all flames, especially for EA.

HCN mole fractions are very high for both sets of flames with peak values up to $12 \%$. This is in line with high HCN mole fractions of about $6 \%$ found in the morpholine flame [17], where the $\mathrm{C} / \mathrm{N}$ ratio in the fuel molecule is 1:4, compared with 1:2 for the fuels studied here, which both show HCN as a likely decomposition product (Fig. 1). Also for the $\Phi=1.8$ pyrrole flame in [15], a high HCN mole fraction of $10 \%$ was reported. It should also be noted that HCN persists longer into the exhaust gas with increasing stoichiometry (compare also the height range of $15 \mathrm{~mm}$ depicted in Fig. 12 in contrast to $10 \mathrm{~mm}$ in the previous figures). Again, trends in the simulations agree very well with the experiment, regarding shapes, peak locations, stoichiometry dependence and ratio between both fuels.

It is interesting at this point, before discussing potential build-up species, to compare the fuel-dependent reactions for the entire fuel decomposition sequence for both fuels towards these small nitrogenated products from the simulations, using a reaction flux analysis in the stoichiometric flames. This is given for EA in Fig. 13, and for DMA in Fig. 14. Regarding the approximative, "blind" character of the modeling, quantitative values should not be overinterpreted, and trends have been highlighted by broad and light arrows, denoting contributions of $\geq 40 \%$ and $<40 \%$, respectively. Some analogies to Fig. 1 are obvious, but Figs. 13 and 14 provide the relative importance in the present model of some of the decomposition steps discussed earlier.

The main sequence for the stoichiometric ethylamine flame proceeds through $\mathrm{CH}_{3} \mathrm{CHNH}_{2}$, the tautomeric pair ethenamine and acetaldimine, with dominant formation of 
the former. Ethenamine reactions provide access to $\mathrm{NH}_{2}$, in combination with $\mathrm{C}_{2} \mathrm{H}_{2}$ as the second reaction product; $\mathrm{NH}_{2}$ may also stem from the less important $\mathrm{CH}_{2} \mathrm{CH}_{2} \mathrm{NH}_{2}$ pathway. $\mathrm{HCN}$ is produced through acetaldimine, which is, however, more dominant in the experiment than in the model, which might be a reason for the under-prediction of HCN in the simulation. Acetonitrile which would also be rationalized to result from acetaldimine reactions is not a noticeable product from this flux analysis, again in contrast to the experiment, explaining its significant under-prediction. The three-membered ring is also not a dominant product from the reaction sequence, which is in line with its small mole fraction found experimentally. One of the key aspects that might need further clarification in the model could thus be the relative importance of the reactions involving $\mathrm{C}_{2} \mathrm{H}_{4} \mathrm{~N}$ isomers.

For the stoichiometric dimethylamine flame, it is interesting to see that the path towards $\mathrm{CH}_{3} \mathrm{NHCH}_{2}$ is noticeably favored over that leading to $\mathrm{CH}_{3} \mathrm{NCH}_{3}$, although there is energetically not much difference. This trend may be an artifact of the model. The rate constants for the $\mathrm{CH}_{3} \mathrm{NHCH}_{3}+\mathrm{H}$ H-abstraction reactions (R190, R191) were estimated by analogy to $\mathrm{CH}_{3} \mathrm{NH}_{2}+\mathrm{H}$. The latter step favors formation of $\mathrm{CH}_{2} \mathrm{NH}_{2}$ to $\mathrm{CH}_{3} \mathrm{NH}$ due to energetic differences, which is not found for $\mathrm{CH}_{3} \mathrm{NHCH}_{2}$ and $\mathrm{CH}_{3} \mathrm{NCH}_{3}$. Dominant products are methanimine, $\mathrm{CH}_{2}=\mathrm{NH}$, and $\mathrm{CH}_{3}$ from the former, and $\mathrm{CH}_{3} \mathrm{~N}=\mathrm{CH}_{2}$ from the latter, which then leads finally to $\mathrm{HCN}$ and $\mathrm{CH}_{3}$ production; appreciable $\mathrm{CH}_{3}$ mole fractions should thus be noted in this flame. The high tendency to form HCN is evident from this flux analysis.

\subsection{7. $\mathrm{HNCO}$ and $\mathrm{NO}_{2}$}

Further small nitrogen species that have been detected in the experiment include HNCO and $\mathrm{NO}_{2}$. The close relation between $\mathrm{HNCO}$ and $\mathrm{HCN}$ in the nitrogenated species interconversion can be clearly seen in the mole fraction profiles shown in Fig. 15. The profiles of the CHNO species identified as isocyanic acid, HNCO, show quite similar tendencies as those of HCN. The other isomers could not be identified. Their presence in small amounts cannot be ruled 
out completely, however, because the PIE curve at that $m / z$ ratio contains already contributions of two species with unknown cross sections. The EI-MBMS signal is thus compared to the sum of all three isomers in the model results. Most of this sum is HNCO, with HOCN making up less than $10 \%$, and only traces of HCNO. The model is qualitatively in quite good agreement, with a tendency to under-predict HNCO mole fractions. Similar behavior was also observed in the morpholine flame [17].

An interesting effect can be seen in the profiles of $\mathrm{NO}_{2}$ given in the lower panels of Fig. 15. $\mathrm{NO}_{2}$ is produced and consumed very early in the flame, a trend that was also noted for morpholine [17]. Although oxygen mole fractions are still relatively high in this region of the flame, substantial NO levels would be needed for direct oxidation, which are not evident on first glance from the later $\mathrm{NO}$ maxima in Fig. 4. The early $\mathrm{NO}_{2}$ peaks below $2 \mathrm{~mm}$ and the stoichiometry dependence are quite well captured by the simulation in both sets of flames, although the quantitative agreement leaves room for improvement, with over-prediction in the EA flames, and under-prediction in the DMA flames. The origin of this early maximum can be understood from the simulations: $\mathrm{NO}_{2}$ is produced by $\mathrm{NO}+\mathrm{HO}_{2}$ very constantly from the start but is mainly consumed in the reaction with $\mathrm{H}$-atom, the mole fraction of which increases quickly with the height above burner.

Another puzzling feature is a second rise of the $\mathrm{NO}_{2}$ mole fraction beyond $\mathrm{h} \sim 4 \mathrm{~mm}$ which is most pronounced towards fuel-lean conditions. This coincides with a luminescence phenomenon noticed only in fuel-lean flames, which occurs at higher heights than the flame front and reaches into the exhaust gas. This luminescence might stem from excited states of $\mathrm{NO}_{2}$, a chemiluminescence which has not been studied in these flames. At this point the model does not consider reactions which might cause this behavior.

\subsubsection{Interconversion of small nitrogenated species}

Regarding the small nitrogen species $\mathrm{NH}_{3}, \mathrm{HCN}, \mathrm{HNCO}, \mathrm{NO}$ and $\mathrm{NO}_{2}$ detected in $\mathrm{EA}$ and 
DMA flames, their inter-conversion reactions have not been analyzed in further detail here, given that they are formed as a consequence of many reaction steps and in view of the approximative character of the model. Some of this small-nitrogen-species chemistry has been discussed for morpholine as a secondary amine fuel [17], derived from an independent, yet also preliminary modeling approach. Maximum mole fractions measured here are in general quite significant, especially in the fuel-rich flames, for $\mathrm{NH}_{3}, \mathrm{HCN}, \mathrm{HNCO}$ and $\mathrm{NO}$, which are all in the percent level, with the exception of ammonia in the DMA flames where it is of the order of $10^{-3}$. The dominant reactions forming and consuming $\mathrm{NO}$ and $\mathrm{NH}_{3}$ in the stoichiometric EA and DMA flames are provided in the reaction flux analysis in Fig. 16, with contributions to formation and consumption of $>10 \%$. Significant differences are seen in the key formation reaction for ammonia, which comes from $\mathrm{CH}_{3} \mathrm{CH}_{2} \mathrm{NH}_{2}$ for EA fuel (compare Fig. 13), whereas direct fuel decomposition reactions play a minor role for $\mathrm{NH}_{3}$ formation in the DMA flames, consistent with the scheme in Figs. 1 and 14. Minor contributions involve species containing two nitrogen atoms for EA, potentially formed by $\mathrm{NH}_{2}$ recombination These reactions are more likely in the EA flames where higher $\mathrm{NH}_{\mathrm{i}}$ levels can be produced by about an order of magnitude (compare Fig. 12). Dominant ammonia consumption reactions are identical for both fuels.

The reaction flux pattern is quite complex for NO, with a large number of similarly important, analogous reactions for both fuels, the relative contribution of which shifts somewhat between the two flames. Subtle differences are noted, with $\mathrm{NH}_{2}$ reactions contributing in the EA flame where this species is more abundant, and $\mathrm{CH}_{3}$ involved in the DMA flame where it can be formed more readily. Also, conversion reactions involve HNO, which was not specifically discussed here. $\mathrm{NO}_{2}$ is seen to be a source of $\mathrm{NO}$, but $\mathrm{NO}$ can also react with $\mathrm{HO}_{2}$, a typical low-temperature species formed early in the flame. These reactions contribute to the NO formation and consumption in both flames, and their balance might be a crucial factor also for the early $\mathrm{NO}_{2}$ maxima discussed above. With fuel-specific reactions 
involved in $\mathrm{NH}_{2} / \mathrm{NH}_{3}$ and $\mathrm{HCN}$ formation, similar as for morpholine [17], and a quite reasonable qualitative, but not yet quantitative agreement of experiment and model, the conversion of fuel-nitrogen from amine fuels remains an intriguing problem.

\subsection{Further selected intermediate species}

As stated above, small hydrocarbon species are expected to be different for both fuels, with more dominant contributions of $\mathrm{C}_{2}$-species in the $\mathrm{EA}$ and formation of $\mathrm{C}_{1}$-species in both the EA and DMA flames, in analogy also to the corresponding ethanol and DME flames. Figure 17 provides methyl and methane mole fraction profiles, and Fig. 18 shows acetylene and ethene profiles. Maximum mole fractions of these representative small hydrocarbons are typically of the order of $10^{-3}$ to $10^{-2}$ and increase with equivalence ratio, as expected. The sequence of maxima shows no strong stoichiometry dependence in the EA flames, and presents a tendency towards later maxima in the DMA flames, as also noted for the $\mathrm{C}_{2} \mathrm{H}_{\mathrm{x}} \mathrm{N}$ intermediates in both cases. In the DMA flames, methyl is formed in combination with $\mathrm{CH}_{2} \mathrm{NH}$ from the dominant pathway through the initial $\mathrm{CH}_{2} \mathrm{NHCH}_{2}$ radical, and also together with $\mathrm{HCN}$ from the acetaldimine sequence (see Figs. 1 and 14). $\mathrm{CH}_{3}$ can also be produced in combination with $\mathrm{CH}_{2} \mathrm{NH}$ in the EA flames through the $\mathrm{CH}_{3} \mathrm{CH}_{2} \mathrm{NH}$ route, with a lower priority, however, since this pathway contributes to the reaction flux only with $16 \%$. A second possibility is $\mathrm{CH}_{3}$ formation in combination with $\mathrm{HCNH}$, as a precursor to $\mathrm{HCN}$. Mole fractions of both methyl and methane are reasonably well predicted in the EA and DMA flames, with about a factor of two difference between experiment and model.

In the EA flames, $\mathrm{C}_{2} \mathrm{H}_{2}$ should be a product together with $\mathrm{NH}_{2}$, from a reaction sequence through ethenamine (see Figs. 1 and 13), while $\mathrm{C}_{2} \mathrm{H}_{4}$ can be a direct product from the initial $\mathrm{CH}_{2} \mathrm{CH}_{2} \mathrm{NH}_{2}$ radical. For the DMA flame, methyl recombination may lead to provide $\mathrm{C}_{2}$-species. As expected, the maximum mole fractions of both $\mathrm{C}_{2}$-intermediates are significantly higher in the EA flames where the fuel structure provides a two-carbon 
sequence. All qualitative trends are well captured by the model, including shapes of profiles, stoichiometry dependence as well as sequence and position of maxima. The quantitative agreement is not as satisfactory, however, with under-predictions ranging from about a factor of 2-3 for $\mathrm{C}_{2} \mathrm{H}_{2}$ in the EA flames and $\mathrm{C}_{2} \mathrm{H}_{4}$ in the DMA flames, to about a factor of 4-5 for $\mathrm{C}_{2} \mathrm{H}_{4}$ in the EA flame and almost an order of magnitude for $\mathrm{C}_{2} \mathrm{H}_{2}$ in the DMA flames. Since simulated values for $\mathrm{CH}_{3}$ are also low for DMA fuel, the effect may influence the $\mathrm{C}_{2}$-species more than linearly if methyl recombination is a dominant source. For the under-estimation of $\mathrm{C}_{2}$-species mole fractions in the EA flame, more than a single reason may be responsible, regarding the more complex reaction network. Of a certain influence may be the correct prediction of the partition between the three $\mathrm{C}_{2} \mathrm{H}_{6} \mathrm{~N}$ radicals, as well as the relative importance of the ethenamine versus the acetaldimine reactions where trends are presently not in agreement with the experiment.

As a last category, some oxygenated intermediates should also be highlighted briefly because they can also contribute to potentially harmful emissions. Figure 19 shows the mole fractions of methanol and formaldehyde as two representatives. Significant fuel-specific influences are not evident, with a somewhat more prominent dependence on the equivalence ratio for DMA, however. Again, the major characteristics of the profiles are well matched between experiment and model. Quantitative agreement is reasonable for $\mathrm{CH}_{2} \mathrm{O}$ in both flames, and for $\mathrm{CH}_{3} \mathrm{OH}$ in the EA flames, whereas methanol is significantly under-predicted in the DMA flames. Given that both species are not primary fuel decomposition results, a more detailed analysis of this discrepancy is regarded as premature.

Further species have been quantified but play no direct role in the fuel destruction path and are thus not in the primary focus of the previous discussion. Thus, only some trends will be noted. For ethane, the simulation matches the shape and absolute mole fractions quite well for DMA, but substantially under-predicts the mole fractions for EA flames. Similar behavior is noted for methylamine $\left(\mathrm{CH}_{3} \mathrm{NH}_{2}\right)$. Ketene is quite well predicted within a factor of two or 
better for both fuels. Acetaldehyde is reasonably well captured in both magnitude and position. All of these noted trends are potentially fortuitous, given the considerable number of steps that may be necessary to form these species, but they may serve as indications for further analysis.

\subsection{Potential pollutants}

We found it interesting for further discussion to compare fuel-rich flames of some selected fuels, all studied under similar premixed low-pressure flame conditions using the same arsenal of techniques, with respect to their potential regarding formation of certain pollutants. This comparison is provided in Table 5, which lists a number of nitrogenated, oxygenated and hydrocarbon species that are undesirable to be emitted from combustion processes, the latter also as proxy for soot and unburnt $\mathrm{HC}$ formation. We have selected the two amines investigated in the present flames, which may also be considered as subsystems for morpholine combustion [17]. Flames of the corresponding isomer pair DME [34,36] and ethanol $[35,36,84]$ are also considered, as well as of cyclohexane [85] as the unsubstituted molecule corresponding to morpholine; further, the compounds identified but not quantified in a pyrrolidine flame [16] as another heterocylic nitrogenated fuel are indicated. The entries provide the peak mole fractions measured in these flames under approximately comparable conditions. The grey shades highlight the highest value that was found for each pollutant; for example, $\mathrm{HCN}$ was noted to have its maximum value of $12 \%$ in the present dimethylamine flame, while propenenitrile, for example was most important in the morpholine flame. Regarding oxygenated species, highest formaldehyde mole fractions of $1.6 \%$ were found in the DME flame, highest methanol mole fractions of $1.6 \%$ in the ethanol flame, and highest acetaldehyde values of $1.2 \%$ also in the ethanol flame. Benzene, not unexpectedly, exhibits highest values in the cyclohexane flame. While these compounds have been reported and discussed in the respective original work, we find the general pattern evident in Table 5 
worthy of further discussion. Regarding the specific contribution of potential pollutants, it is no surprise that not a single fuel appears fully "clean" under these conditions. Certainly, it cannot be assumed that all components reported in Table 5 would persist into the exhaust, especially if different pressure and temperature conditions are considered; however, some indications exist that components currently debated in fundamental studies may also be found in combustion exhaust from technical devices such as internal combustion engines and in urban air [86-88]. Such components may also have to be considered in aftertreatment of combustion processes.

Glarborg et al. [2] concluded in their review of fuel-N chemistry that the initial Nspeciation in flames had only a small influence on the selectivity to form $\mathrm{NO}$ or $\mathrm{N}_{2}$. Rather, earlier flame studies $[89,90]$ indicated that variations in NO yield could primarily be attributed to differences in fuel-N content and residence time effects. At the high temperatures prevailing in flames, the nitrogen atom in the fuel-nitrogen species was suggested to sequentially be stripped of the $\mathrm{H}$ - and $\mathrm{C}$-elements it was bonded to, ending up as $\mathrm{NH}$ or $\mathrm{N}$; reactions of these radicals would then determine the NO yield.

The current flames are different from those discussed above in that the fuel-N species are not present only in trace amounts, but constitute the fuel. We observe that the NO yields are clearly different for EA and DMA under stoichiometric and oxidizing conditions, while similar levels are observed under reducing conditions (Fig. 4). In addition to the structural differences between the two amines, also changes in the flame temperature and radical pool composition could contribute to the observed differences in NO. To assess the impact of the structure of the $\mathrm{N}$-species, we conducted a set of flame calculations where the fuel-N was added in smaller quantities to a $\mathrm{CH}_{4}$ flame, i.e., conditions similar to those studied by Tian et al. [13] for a range of stoichiometric $\mathrm{CH}_{4} / \mathrm{NH}_{3}$ flames (for our purpose with fuel-N/CH $4=$ 0.1). Using the measured temperature profile [13], independent of fuel-N speciation, and with $\mathrm{CH}_{4}$ in significant excess to minimize differences in the radical pool composition, variation in 
the NO yield could then be attributed to differences in fuel-N structure. The modeling results (see Supplementary Material 5) showed that DMA had a larger selectivity towards NO than EA, consistent with the results of Fig. 4. However, the difference in NO yield was smaller than that observed in Fig. 4, indicating that also changes in the flame temperature and/or radical pool composition contribute to the selectivity to form NO in the pure amine flames. Notably, the predicted $\mathrm{NO}$ yield for $\mathrm{NH}_{3}$ as fuel-N additive was comparable to, but slightly larger than, that of DMA, while addition of $\mathrm{HCN}$ resulted in the highest NO concentration, about $30 \%$ higher than for EA. The calculations indicate that fuel-N species that oxidize through cyanides rather than amines, are likely to have a larger NO yield, consistent with the results for DMA and EA.

\section{Summary and conclusions}

The present study has been devoted to an analysis of the smallest isomeric pair of amine fuels, ethylamine and dimethylamine. Such amine fuels present important structural aspects that may be characteristic also of larger fuel components in biomass. The experimental investigation of three pairs of flames of different stoichiometries has revealed fuel-specific reaction sequences and characteristic intermediate species compositions for both fuels. A detailed reaction mechanism has been developed for both fuels, with thermochemical values for a number of compounds derived from quantum chemistry. Modeling of the complete set of flames has resulted in good agreement for major species and quite good qualitative agreement for most intermediates, regarding mole fraction profiles, location of maxima, and stoichiometry dependence, while differences remain in quantitative comparison of experiment and model. The cascade of species derived from the first fuel decomposition steps have been discussed with higher emphasis, since it was assumed that the model would reflect earlier steps in the reaction sequences with higher predictive capability. Further priority has been given to characteristic traits such as the formation of small nitrogenated species. $\mathrm{NO}$ and $\mathrm{N}_{2}$ 
as final fuel-bound nitrogen products are quite well predicted, and NO mole fractions reach up to $4 \%$ in the burnt gases. Remarkable results for the combustion of these small amines are also the high $\mathrm{HCN}$ mole fractions which attain up to $12 \%$ and persist well into the burnt gas, as well as the larger tendency to form ammonia, up to $1.5 \%$, in the ethylamine flame. In spite of the perceived "simple" structure of these fuels, the reaction cascades are quite involved and present a challenge to quantitative simulation. Prediction of nitrogen conversion and small, potentially harmful and toxic components cannot be derived merely from flames of small hydrocarbons doped with ammonia, since fuel-specific reactions play an important role in their reliable simulation. The present character of the model for the two amine isomers, in spite of the large effort in its development, must still be regarded as approximation. Some trends which are seen in the experiments, such as the ratio between ethenamine and acetaldimine, and the significant formation of acetonitrile, are not congruent with the model, and further effort should be devoted to improve the underlying kinetics for key reaction steps. The prediction of fuel-nitrogen conversion for more complex fuels, such as the previously investigated morpholine, where an independent model was developed, may have to await further improvement of the detailed mechanism for smaller amines. It is striking to our opinion how much more fundamental information is missing for the reliable simulation of amine combustion in comparison to the better-understood fuel analogues ethanol and dimethylether. Substitution of carbon by a heteroatom provides an important increase in the number of intermediates that can be produced via $\mathrm{H}$-abstraction reactions, and reaction schemes are not to be assumed as analogous between the apparently simple fuel structures such as, for example, DMA and DME, neither regarding bond dissociation energies nor reaction rates. As one important conclusion we would thus like to advise that complete and reasonable reliable mechanisms should be conceived and tested for simpler fuel structures with heteroatoms first, including experiments and simulations under different pressure and temperature conditions, e.g, in shock tubes and flow reactors as complementary to flames, 
since they tend to be also submechanisms for the combustion of more complex fuel molecules.

\section{Acknowledgements}

PM thanks Profs. John Barker (University of Michigan) and Wes Borden (University of North Texas) for valuable discussions. The work at UNT was supported by the R.A. Welch Foundation (Grant B-1174) and the National Science Foundation (Grant CBET-0756144), and computer facilities were purchased with NSF Grant CHE-0741936. PG acknowledges financial support from ERANET project. The work in Bielefeld was in part supported by Deutsche Forschungsgemeinschaft under contract KO 1363/18-3. 
Table 1: Flame conditions. The flows are reported for the $63.4 \mathrm{~mm}$ burner used in the EIMBMS experiment, pressure is 40 mbar, and cold gas velocity is given at $313 \mathrm{~K}$. The flow rates for the $60 \mathrm{~mm}$ burner (divide values in table by 1.12 for conversion) were chosen to match cold gas velocity in both experiments.

\begin{tabular}{|l|c|c|c|c|c|c|}
\hline & \multicolumn{3}{|c|}{ Ethylamine (EA) } & \multicolumn{3}{c|}{ Dimethylamine (DMA) } \\
\hline Flame & EA08 & EA10 & EA13 & DMA08 & DMA10 & DMA13 \\
\hline Stoichiometry & 0.8 & 1.0 & 1.3 & 0.8 & 1.0 & 1.3 \\
\hline Flow Ar [slm] & 0.56 & 0.56 & 0.56 & 0.56 & 0.56 & 0.56 \\
\hline Flow $\mathrm{O}_{2}[\mathrm{slm}]$ & 1.38 & 1.32 & 1.24 & 1.38 & 1.32 & 1.24 \\
\hline Flow fuel [slm] & 0.29 & 0.35 & 0.43 & 0.29 & 0.35 & 0.43 \\
\hline Velocity [cm/s] & 34 & 34 & 34 & 34 & 34 & 34 \\
\hline Mass flow [10 & & & & & & 1.92 \\
\hline
\end{tabular}


Table 2: Thermodynamic properties for selected species in the amine subset. Units are kcal $\mathrm{mol}^{-1}\left(\mathrm{H}_{\mathrm{f}, 298}\right)$ and cal $\mathrm{mol}^{-1} \mathrm{~K}^{-1}\left(\mathrm{~S}_{298}, \mathrm{Cp}\right)$. All data were estimated in the present work, with the exception of $\mathrm{H}_{\mathrm{f}, 298}$ for $\mathrm{CH}_{3} \mathrm{CH}_{2} \mathrm{NH}_{2}$ [41] and data for $\mathrm{H}_{2} \mathrm{NCHO}$ and $\mathrm{H}_{2} \mathrm{NCO}$ [49].

\begin{tabular}{|c|c|c|c|c|c|c|c|c|c|}
\hline Species & $\mathrm{H}_{\mathrm{f}, 298}$ & $\mathrm{~S}_{298}$ & $\mathrm{Cp}_{300}$ & $\mathrm{Cp}_{400}$ & $\mathrm{Cp}_{500}$ & $\mathrm{Cp}_{600}$ & $\mathrm{Cp}_{800}$ & $\mathrm{Cp}_{1000}$ & $\mathrm{Cp}_{1500}$ \\
\hline $\mathrm{CH}_{3} \mathrm{CH}_{2} \mathrm{NH}_{2}$ & -11.97 & 66.95 & 17.18 & 21.33 & 24.98 & 28.17 & 33.37 & 37.34 & 43.88 \\
\hline $\mathrm{CH}_{2} \mathrm{CH}_{2} \mathrm{NH}_{2}$ & 38.16 & 69.39 & 17.05 & 20.62 & 23.68 & 26.32 & 30.59 & 33.85 & 39.30 \\
\hline $\mathrm{CH}_{3} \mathrm{CHNH}_{2}$ & 28.06 & 68.69 & 17.26 & 20.76 & 23.80 & 26.44 & 30.71 & 33.97 & 39.40 \\
\hline $\mathrm{CH}_{3} \mathrm{CH}_{2} \mathrm{NH}$ & 36.70 & 68.53 & 16.53 & 20.05 & 23.19 & 25.98 & 30.55 & 34.00 & 39.59 \\
\hline $\mathrm{CH}_{2} \mathrm{CHNH}_{2}$ & 9.43 & 62.40 & 15.34 & 18.99 & 21.97 & 24.40 & 28.13 & 30.89 & 35.49 \\
\hline $\mathrm{CH}_{3} \mathrm{CHNH}$ & 12.24 & 63.41 & 13.89 & 16.99 & 19.90 & 22.54 & 26.92 & 30.17 & 35.35 \\
\hline $\mathrm{CH}_{2} \mathrm{CHNH}$ & 48.93 & 62.18 & 13.48 & 16.75 & 19.48 & 21.77 & 25.29 & 27.82 & 31.85 \\
\hline $\mathrm{CHCHNH}_{2}$ & 74.72 & 63.50 & 14.99 & 17.99 & 20.43 & 22.44 & 25.53 & 27.84 & 31.68 \\
\hline $\mathrm{CH}_{3} \mathrm{CHN}$ & 47.68 & 64.35 & 13.68 & 16.22 & 18.57 & 20.69 & 24.21 & 26.84 & 30.99 \\
\hline $\mathrm{CH}_{3} \mathrm{CNH}$ & 53.54 & 64.57 & 13.62 & 16.35 & 18.82 & 20.99 & 24.46 & 26.91 & 30.67 \\
\hline $\mathrm{CH}_{2} \mathrm{CNH}_{2}$ & 64.23 & 65.98 & 15.62 & 18.24 & 20.42 & 22.27 & 25.21 & 27.48 & 31.12 \\
\hline $\mathrm{CHCNH}_{2}$ & 55.52 & 57.86 & 13.65 & 15.82 & 17.53 & 18.91 & 21.07 & 22.79 & 25.79 \\
\hline $\mathrm{CH}_{2} \mathrm{CNH}$ & 44.69 & 59.75 & 13.13 & 15.66 & 17.71 & 19.39 & 21.97 & 23.90 & 27.06 \\
\hline $\mathrm{CH}_{2} \mathrm{CHN}$ & 85.41 & 62.53 & 12.86 & 15.59 & 17.84 & 19.70 & 22.51 & 24.53 & 27.75 \\
\hline $\mathrm{CH}_{2} \mathrm{CHN}(\mathrm{s})$ & 100.41 & 62.53 & 12.86 & 15.59 & 17.84 & 19.70 & 22.51 & 24.53 & 27.75 \\
\hline $\mathrm{c}-\mathrm{C}_{2} \mathrm{H}_{3} \mathrm{~N}$ & 64.17 & 58.79 & 11.17 & 13.96 & 16.35 & 18.38 & 21.50 & 23.69 & 27.09 \\
\hline CHCNH & 94.20 & 60.98 & 14.02 & 15.64 & 16.90 & 17.90 & 19.42 & 20.61 & 22.62 \\
\hline $\mathrm{H}_{2} \mathrm{NCHO}$ & -46.67 & 60.61 & 11.63 & 14.06 & 16.35 & 18.34 & 21.31 & 23.54 & 26.97 \\
\hline $\mathrm{H}_{2} \mathrm{NCO}$ & -5.57 & 61.28 & 12.68 & 14.23 & 15.60 & 16.78 & 18.63 & 20.03 & 22.24 \\
\hline $\mathrm{CH}_{3} \mathrm{NHCH}_{3}$ & -4.57 & 65.52 & 16.77 & 20.88 & 24.59 & 27.90 & 33.34 & 37.45 & 44.08 \\
\hline $\mathrm{CH}_{3} \mathrm{NHCH}_{2}$ & 36.21 & 66.91 & 17.17 & 20.70 & 23.78 & 26.46 & 30.81 & 34.11 & 39.53 \\
\hline $\mathrm{CH}_{3} \mathrm{NCH}_{3}$ & 37.62 & 70.19 & 15.30 & 18.55 & 21.72 & 24.70 & 29.74 & 33.50 & 39.45 \\
\hline $\mathrm{CH}_{3} \mathrm{NCH}_{2}$ & 17.30 & 62.66 & 14.10 & 17.21 & 20.11 & 22.73 & 27.10 & 30.37 & 35.55 \\
\hline $\mathrm{CH}_{2} \mathrm{NCH}_{2}$ & 53.71 & 61.49 & 14.26 & 17.41 & 20.12 & 22.43 & 26.03 & 28.60 & 32.47 \\
\hline $\mathrm{CH}_{3} \mathrm{NCH}$ & 62.43 & 64.41 & 13.43 & 16.08 & 18.53 & 20.74 & 24.30 & 26.82 & 30.67 \\
\hline
\end{tabular}


Table 3: Species overview from experiment and simulation in the ethylamine flames: Maximum mole fractions $x$ at height $h_{\max }$ are reported for species measured by EI-MBMS. In addition, for several species with sum formula $\mathrm{C}_{2} \mathrm{H}_{\mathrm{x}} \mathrm{N}$, individual isomers are given from PI-MBMS measurements in the $\Phi=1.3$ flame. Simulations provide sum and individual isomer mole fractions, also in cases where the latter were not determined experimentally. IE: ionization energy, n.i.: not identified, n.a.: not applicable.

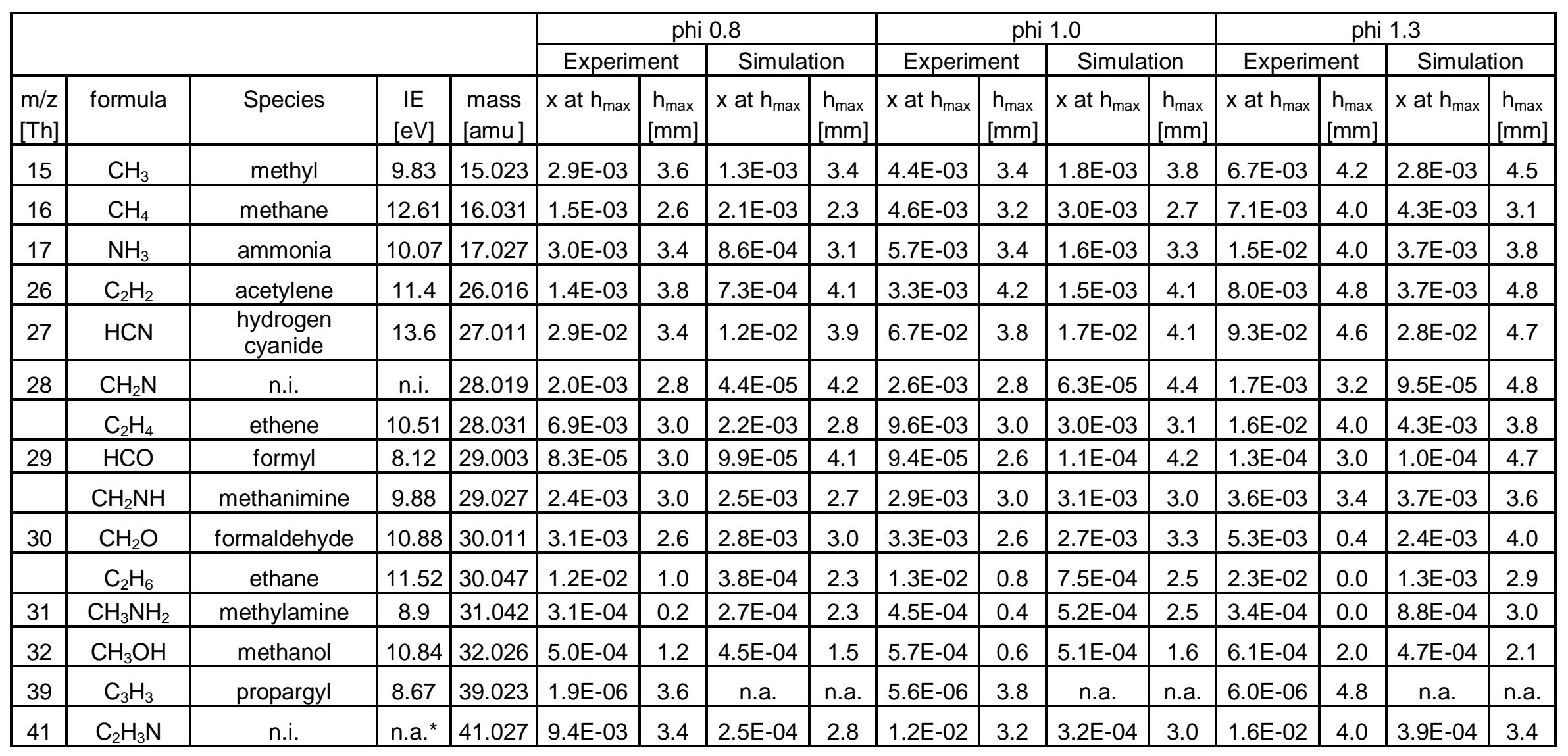




\begin{tabular}{|c|c|c|c|c|c|c|c|c|c|c|c|c|c|c|c|c|}
\hline & $\mathrm{C}_{2} \mathrm{H}_{3} \mathrm{~N}$ & $2 H$-azirine & 10.58 & 41.027 & n.a & n.a & $3.2 \mathrm{E}-07$ & 1.6 & n.a & n.a & $1.1 \mathrm{E}-06$ & 1.9 & 4.4E-05 & 2.0 & 2.3E-06 & 2.5 \\
\hline & $\mathrm{CH}_{3} \mathrm{CN}$ & acetonitrile & 12.2 & 41.027 & n.a & n.a & 2.5E-04 & 2.8 & n.a & n.a & $3.2 \mathrm{E}-04$ & 3.0 & 1.3E-02 & 3.5 & $3.9 \mathrm{E}-04$ & 3.4 \\
\hline \multirow[t]{2}{*}{42} & $\mathrm{C}_{2} \mathrm{H}_{2} \mathrm{O}$ & ketene & 9.61 & 42.011 & $1.5 \mathrm{E}-04$ & 4.0 & 7.6E-05 & 4.1 & 1.7E-04 & 3.8 & 8.6E-05 & 4.2 & 2.4E-04 & 4.8 & 1.1E-04 & 4.8 \\
\hline & $\mathrm{C}_{2} \mathrm{H}_{4} \mathrm{~N}$ & n.i. & n.i. & 42.034 & 1.2E-03 & 2.6 & $1.2 \mathrm{E}-04$ & 3.8 & 1.7E-03 & 2.6 & 1.3E-04 & 4.1 & 2.5E-03 & 3.2 & 1.3E-04 & 4.5 \\
\hline \multirow[t]{4}{*}{43} & $\mathrm{HNCO}$ & isocyanic acid & 11.6 & 43.006 & $6.4 \mathrm{E}-03$ & 4.2 & $3.0 \mathrm{E}-03$ & 3.8 & $7.8 \mathrm{E}-03$ & 4.8 & $2.5 \mathrm{E}-03$ & 4.0 & $9.2 \mathrm{E}-03$ & 5.6 & $2.3 \mathrm{E}-03$ & 4.8 \\
\hline & $\mathrm{C}_{2} \mathrm{H}_{5} \mathrm{~N}$ & n.i. & n.a. ${ }^{*}$ & 43.042 & $9.2 \mathrm{E}-03$ & 3.0 & $1.5 \mathrm{E}-02$ & 2.2 & $1.2 \mathrm{E}-02$ & 3.0 & 1.6E-02 & 3.0 & $1.4 \mathrm{E}-02$ & 3.4 & $1.5 \mathrm{E}-02$ & 3.1 \\
\hline & $\mathrm{C}_{2} \mathrm{H}_{3} \mathrm{NH}_{2}$ & ethenamine & 8.2 & 43.042 & n.a & n.a & $1.3 \mathrm{E}-02$ & 2.0 & n.a & n.a & $1.4 \mathrm{E}-02$ & 2.1 & $9.1 \mathrm{E}-04$ & 3.8 & $1.2 \mathrm{E}-02$ & 2.6 \\
\hline & $\mathrm{CH}_{3} \mathrm{CHNH}$ & acetaldimine & 9.7 & 43.042 & n.a & n.a & $2.5 \mathrm{E}-03$ & 2.8 & n.a & n.a & $2.5 \mathrm{E}-03$ & 3.0 & $6.5 \mathrm{E}-03$ & 3.5 & 2.3E-03 & 3.5 \\
\hline \multirow[t]{2}{*}{44} & $\mathrm{CH}_{3} \mathrm{CHO}$ & acetaldehyde & 10.23 & 44.026 & 3.9E-04 & 3.0 & 8.5E-05 & 3.1 & 4.0E-04 & 3.2 & 1.1E-04 & 3.2 & 3.7E-05 & 3.2 & 1.1E-04 & 3.6 \\
\hline & $\mathrm{C}_{2} \mathrm{H}_{6} \mathrm{~N}$ & n.i. & n.i. & 44.05 & 4.4E-04 & 0.8 & 3.7E-04 & 2.3 & $1.1 \mathrm{E}-03$ & 0.0 & 3.7E-04 & 2.3 & 7.7E-04 & 0.2 & 3.4E-04 & 2.9 \\
\hline 45 & $\mathrm{C}_{2} \mathrm{H}_{5} \mathrm{NH}_{2}$ & ethylamine & 9.1 & 45.058 & $6.5 \mathrm{E}-02$ & 0.2 & $9.3 \mathrm{E}-02$ & 0.0 & $1.4 \mathrm{E}-01$ & 0.0 & $1.2 \mathrm{E}-01$ & 0.0 & $1.6 \mathrm{E}-01$ & 0.6 & $1.6 \mathrm{E}-01$ & 0.0 \\
\hline 46 & $\mathrm{NO}_{2}$ & nitrogen dioxide & 9.58 & 45.993 & 2.4E-04 & 1.0 & 2.0E-03 & 0.9 & $1.8 \mathrm{E}-04$ & 0.8 & $1.8 \mathrm{E}-03$ & 0.9 & $6.2 \mathrm{E}-05$ & 0.8 & $1.3 \mathrm{E}-03$ & 1.6 \\
\hline
\end{tabular}

* In the quantitative evaluation from EI-MBMS, the IE for $\mathrm{C}_{2} \mathrm{H}_{3} \mathrm{~N}$ has been assumed as $12.2 \mathrm{eV}$ and for $\mathrm{C}_{2} \mathrm{H}_{5} \mathrm{~N}$ as $9.7 \mathrm{eV}$. 
Table 4: Species overview from experiment and simulation in the dimethylamine flames: Maximum mole fractions $x$ at height $h_{\text {max }}$ are reported for species measured by EI-MBMS. In addition, for several species with sum formula $\mathrm{C}_{2} \mathrm{H}_{\mathrm{x}} \mathrm{N}$, individual isomers are given from PI-MBMS measurements in the $\Phi=1.3$ flame. Simulations provide sum and individual isomer mole fractions, also in cases where the latter were not determined experimentally. IE: ionization energy, n.i.: not identified, n.a.: not applicable.

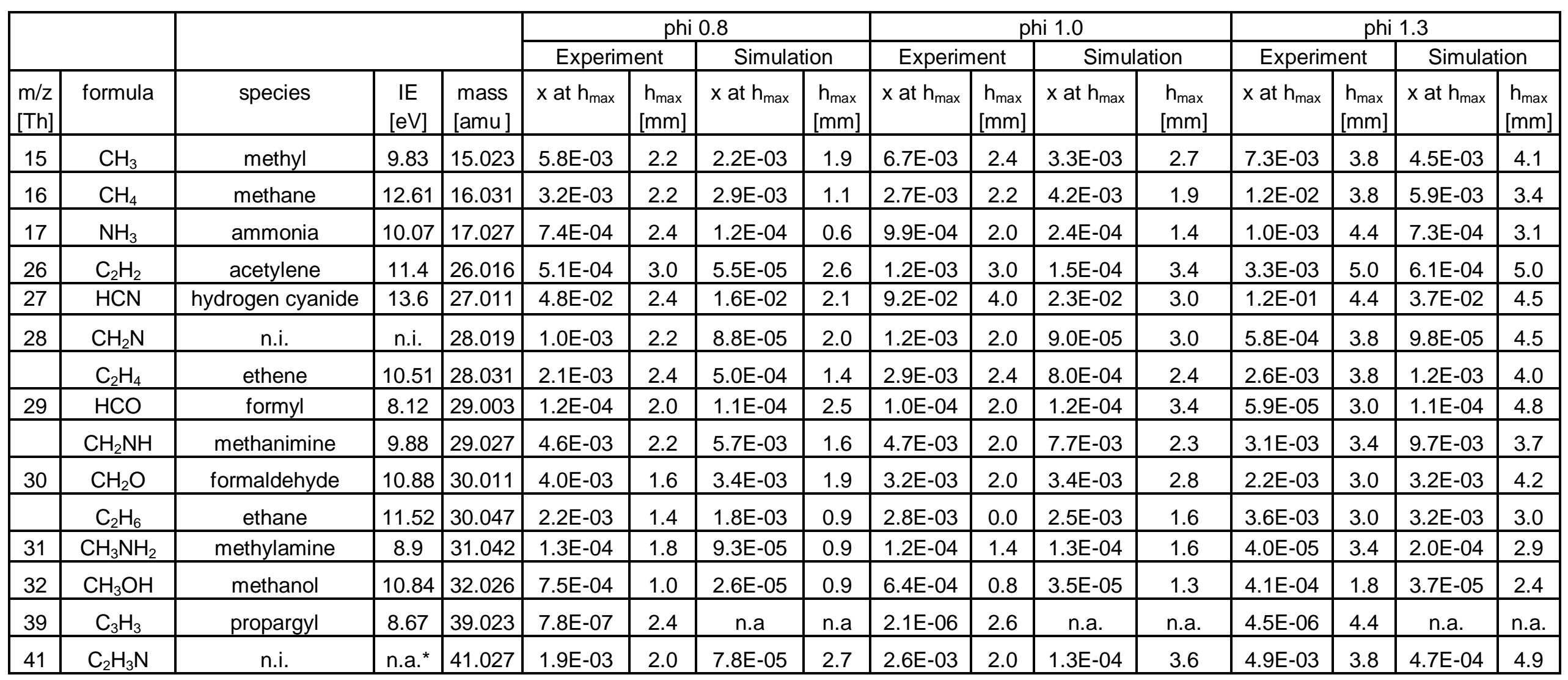




\begin{tabular}{|c|c|c|c|c|c|c|c|c|c|c|c|c|c|c|c|c|}
\hline & $\mathrm{C}_{2} \mathrm{H}_{3} \mathrm{~N}$ & $2 \mathrm{H}$-azirine & 10.58 & 41.027 & n.a & n.a & $1.5 \mathrm{E}-07$ & 0.5 & n.a & n.a & 2.3E-07 & 1.3 & $9.2 \mathrm{E}-05$ & 1.8 & $3.1 \mathrm{E}-07$ & 2.7 \\
\hline & $\mathrm{CH}_{3} \mathrm{CN}$ & acetonitrile & 12.2 & 41.027 & n.a & n.a & 7.8E-05 & 2.7 & n.a & n.a & 1.3E-04 & 3.6 & 4.1E-03 & 4.5 & 4.7E-04 & 4.9 \\
\hline \multirow[t]{2}{*}{42} & $\mathrm{C}_{2} \mathrm{H}_{2} \mathrm{O}$ & ketene & 9.61 & 42.011 & 5.9E-05 & 0.0 & 2.3E-05 & 2.3 & 4.5E-05 & 0.0 & 2.9E-05 & 3.2 & 4.6E-05 & 5.0 & 3.6E-05 & 4.5 \\
\hline & $\mathrm{C}_{2} \mathrm{H}_{4} \mathrm{~N}$ & n.i. & n.i. & 42.034 & 4.3E-03 & 1.6 & 1.3E-04 & 2.2 & $3.5 \mathrm{E}-03$ & 1.4 & $1.2 \mathrm{E}-04$ & 3.0 & 1.3E-03 & 3.0 & $1.1 \mathrm{E}-04$ & 4.3 \\
\hline \multirow[t]{5}{*}{43} & $\mathrm{HNCO}$ & isocyanic acid & 11.6 & 43.006 & 8.2E-03 & 3.0 & 1.3E-03 & 3.0 & 9.6E-03 & 4.0 & 1.6E-03 & 4.1 & $1.2 \mathrm{E}-02$ & 5.6 & 2.6E-03 & 5.4 \\
\hline & $\mathrm{C}_{2} \mathrm{H}_{5} \mathrm{~N}$ & n.i. & n.a.* & 43.042 & 2.6E-02 & 1.6 & 7.0E-03 & 1.3 & 2.1E-02 & 1.4 & 7.9E-03 & 2.3 & 7.5E-03 & 2.8 & 8.3E-03 & 3.8 \\
\hline & $\mathrm{C}_{2} \mathrm{H}_{3} \mathrm{NH}_{2}$ & ethenamine & 8.2 & 43.042 & n.a & n.a & $3.2 \mathrm{E}-05$ & 1.1 & n.a & n.a & 5.0E-05 & 1.8 & $6.0 \mathrm{E}-04$ & 3.0 & 7.0E-05 & 3.1 \\
\hline & $\mathrm{CH}_{3} \mathrm{CHNH}$ & acetaldimine & 9.7 & 43.042 & n.a & n.a & $1.2 \mathrm{E}-05$ & 1.6 & n.a & n.a & $1.8 \mathrm{E}-05$ & 2.3 & n.a. & n.a. & $2.5 \mathrm{E}-05$ & 3.7 \\
\hline & $\mathrm{CH}_{3} \mathrm{NCH}_{2}$ & $\begin{array}{c}\mathrm{N} \text {-methyl- } \\
\text { methanimine }\end{array}$ & 9.4 & 43.042 & n.a & n.a & $6.9 \mathrm{E}-03$ & 1.0 & n.a & n.a & $7.8 \mathrm{E}-03$ & 1.9 & $7.2 \mathrm{E}-03$ & 3.2 & 8.1E-03 & 3.7 \\
\hline \multirow[t]{2}{*}{44} & $\mathrm{CH}_{3} \mathrm{CHO}$ & acetaldehyde & 10.23 & 44.026 & 6.7E-04 & 0.0 & $1.1 \mathrm{E}-04$ & 1.7 & 2.3E-04 & 0.0 & $1.4 \mathrm{E}-04$ & 2.4 & 2.2E-05 & 0.6 & $1.5 \mathrm{E}-04$ & 3.7 \\
\hline & $\mathrm{C}_{2} \mathrm{H}_{6} \mathrm{~N}$ & n.i. & n.i. & 44.05 & $6.3 \mathrm{E}-03$ & 0.0 & 1.7E-03 & 1.6 & 9.3E-03 & 0.0 & 1.6E-03 & 2.4 & $9.8 \mathrm{E}-03$ & 0.2 & 1.7E-03 & 4.1 \\
\hline 45 & $\mathrm{C}_{2} \mathrm{H}_{5} \mathrm{NH}_{2}$ & dimethylamine & 9.1 & 45.058 & 7.0E-02 & 0.2 & 6.7E-02 & 0.0 & 9.3E-02 & 0.0 & 1.1E-01 & 0.0 & $1.5 \mathrm{E}-01$ & 0.0 & 1.6E-01 & 0.0 \\
\hline 46 & $\mathrm{NO}_{2}$ & nitrogen dioxide & 9.58 & 45.993 & 2.3E-04 & 0.0 & 5.1E-05 & 0.3 & 1.6E-04 & 0.0 & 8.8E-05 & 0.3 & 7.5E-05 & 0.2 & 9.9E-05 & 1.6 \\
\hline
\end{tabular}

* In the quantitative evaluation from EI-MBMS, the IE for $\mathrm{C}_{2} \mathrm{H}_{3} \mathrm{~N}$ has been assumed as $12.2 \mathrm{eV}$ and for $\mathrm{C}_{2} \mathrm{H}_{5} \mathrm{~N}$ as $9.4 \mathrm{eV}$. 
Table 5: Comparison of maximum mole fractions for potential pollutants in flames of different fuels. Grey shades indicate the highest value for each pollutant.

\begin{tabular}{|c|c|c|c|c|c|c|c|c|}
\hline $\begin{array}{l}\text { fuel } \\
\text { [Ref.] }\end{array}$ & potential & DMA & EA & $\begin{array}{c}\text { morpholine } \\
\text { [17] }\end{array}$ & $\begin{array}{c}\text { pyrrolidine } \\
{[16]}\end{array}$ & $\begin{array}{c}\text { DME } \\
{[34,36]}\end{array}$ & $\begin{array}{c}\text { ethanol } \\
\text { [84] }\end{array}$ & $\begin{array}{c}\text { cyclohexane } \\
\text { [85] }\end{array}$ \\
\hline equivalence ratio & & 1.3 & 1.3 & 1.3 & 1.3 & 1.4 & 1.1 & 1.0 \\
\hline ammonia & $\mathrm{T}, \mathrm{C}, \mathrm{N}$ & $1.0 \mathrm{E}-03$ & $1.5 \mathrm{E}-02$ & $2.5 \mathrm{E}-03$ & $\bar{x}$ & - & - & - \\
\hline hydrogen cyanide & $\mathrm{T}, \mathrm{F}, \mathrm{N}$ & $1.2 \mathrm{E}-01$ & $9.2 \mathrm{E}-02$ & $6.0 \mathrm{E}-02$ & $x$ & - & - & - \\
\hline methylamidogene & n.c. & $5.0 \mathrm{E}-04$ & $1.6 \mathrm{E}-03$ & $2.8 \mathrm{E}-03$ & - & - & - & - \\
\hline methanimine & n.c. & $3.1 \mathrm{E}-03$ & $3.6 \mathrm{E}-03$ & $9.0 \mathrm{E}-03$ & $\bar{x}$ & - & - & - \\
\hline nitric oxide & $\mathrm{T}, \mathrm{C}$ & $1.1 \mathrm{E}-02$ & $1.1 \mathrm{E}-02$ & $2.3 \mathrm{E}-02$ & $\bar{x}$ & - & - & - \\
\hline formaldehyde & $\mathrm{T}, \mathrm{C}, \mathrm{K}$ & $2.2 \mathrm{E}-03$ & $5.2 \mathrm{E}-03$ & $1.5 \mathrm{E}-03$ & $\bar{x}$ & $1.6 \mathrm{E}-02$ & $7.4 \mathrm{E}-03$ & $1 \mathrm{E}-03$ \\
\hline methanol & $\mathrm{T}, \mathrm{F}, \mathrm{O}$ & 4.0E-04 & $6.0 \mathrm{E}-04$ & $7.2 \mathrm{E}-04$ & $x$ & $1.5 \mathrm{E}-03$ & $1.6 \mathrm{E}-02$ & $2 \mathrm{E}-04$ \\
\hline isocyanic acid & n.c. & $1.2 \mathrm{E}-02$ & $9.2 \mathrm{E}-03$ & $8.2 \mathrm{E}-03$ & $\bar{x}$ & - & - & - \\
\hline $2 \mathrm{H}$-azirine & n.c. & 8.0E-05 & $4.0 \mathrm{E}-05$ & $8.8 \mathrm{E}-04$ & - & - & - & - \\
\hline acetonitrile & $\mathrm{Xn}, \mathrm{F}$ & $4.2 \mathrm{E}-03$ & $1.3 \mathrm{E}-02$ & $1.4 \mathrm{E}-03$ & $\bar{x}$ & - & $\overline{-}$ & \\
\hline ketene & $\mathrm{Xn}$ & $5.3 \mathrm{E}-05$ & $2.5 \mathrm{E}-04$ & $2.5 \mathrm{E}-04$ & $\bar{x}$ & $8 \mathrm{E}-05$ & $1.4 \mathrm{E}-03$ & $4 \mathrm{E}-05$ \\
\hline ethenamine & n.c. & $6.0 \mathrm{E}-04$ & $9.1 \mathrm{E}-04$ & $3.8 \mathrm{E}-04$ & $\bar{x}$ & - & - & - \\
\hline acetaldimine & n.c. & - & $6.5 \mathrm{E}-03$ & $4.5 \mathrm{E}-03$ & - & - & - & - \\
\hline propenenitrile & $\mathrm{T}, \mathrm{C}, \mathrm{N}, \mathrm{K}$ & 5.4E-05 & $1.9 \mathrm{E}-04$ & $4.8 \mathrm{E}-04$ & $\bar{x}$ & - & - & - \\
\hline acetaldehyde & $\mathrm{Xn}, \mathrm{F}, \mathrm{K}$ & $2.2 \mathrm{E}-05$ & 3.7E-05 & $9.0 \mathrm{E}-04$ & $\bar{x}$ & $5.5 \mathrm{E}-04$ & $1.2 \mathrm{E}-02$ & $3 E-04$ \\
\hline propargyl & n.c. & 4.0E-06 & $6.0 \mathrm{E}-06$ & $4.8 \mathrm{E}-05$ & $x$ & - & $2.0 \mathrm{E}-05$ & $9 \mathrm{E}-05$ \\
\hline benzene & $\mathrm{T}, \mathrm{F}, \mathrm{K}$ & - & - & - & $\bar{x}$ & - & - & $4 \mathrm{E}-04$ \\
\hline
\end{tabular}

T: toxic; C: corrosive; F: flammable; N: hazard to nature; O: organ destruction;

$\mathrm{K}$ : carcinogen; $\mathrm{Xn}$ : harmful; n.c.: not classified;

-: not detected; $x$ : identified, but not quantified 


\section{References}

[1] J. A. Miller, C. T. Bowman, Prog. Energy Combust. Sci. 15 (1989) 287-338.

[2] P. Glarborg, A. D. Jensen, J. E. Johnsson, Prog. Energy Combust. Sci. 29 (2003) 89-13.

[3] P. Dagaut, P. Glarborg, M. U. Alzueta, Prog. Energy Combust. Sci. 34 (2008) 1-46.

[4] S. Hansen, P. Glarborg, Energy Fuels 24 (2010) 2883-2890.

[5] S. Garner, T. Dubois, C. Togbé, N. Chaumeix, P. Dagaut, K. Brezinsky, Combust. Flame 158 (2011) 2302-2313.

[6] J. Giuntoli, W. de Jong, A. H. M. Verkooijen, P. Piotowska, M. Zevenhoven, M. Hupa, Energy Fuels 24 (2010) 5309-5319.

[7] Q. Ren, C. Zhao, L. Duan, X Chen, Bioresource Techn. 102 (2011) 7211-7217.

[8] C. Wu, D. Tree, L. Baxter, Proc. Combust. Inst. 31 (2007) 2787-2794.

[9] G. Stubenberger, R. Scharler, S. Zahirović, I. Obernberger, Fuel 87 (2008) 793-806.

[10] Y. Zhang, J. Zhang, C. Sheng, Y. Liu, L. Zhao, Q. Ding, Energy Fuels 25 (2011) 11461152.

[11] T. Mendiara, P. Glarborg, Combust. Flame 156 (2009) 1937-1949.

[12] L. I. Darvell, J. M. Jones, B. Gudlea, X. C. Baxter, A. Saddawi, A. Williams, A. Malmgren, Fuel 89 (2010) 2881-2890.

[13] Z. Tian, Y. Li, L. Zhang, P. Glarborg, F. Qi, Combust. Flame 156 (2009) 1413-1426.

[14] Z. Tian, Y. Li, T. Zhang, A. Zhu, F. Qi, J. Phys. Chem. A 112 (2008) 13549-13555.

[15] Z. Tian, Y. Li, T. Zhang, A. Zhu, Z. Cui, F. Qi, Combust. Flame 151 (2007) 347-365.

[16] Z. Wang, A. Lucassen, L. Zhang, J. Yang, K. Kohse-Höinghaus, F. Qi, Proc. Combust. Inst. 33 (2011) 415-428.

[17] A. Lucassen, N. Labbe, P. R. Westmoreland, K. Kohse-Höinghaus, Combust. Flame 158, 2011, 1647-1666. 
[18] P. Nau, A. Seipel, A. Lucassen, A. Brockhinke, K. Kohse-Höinghaus, Exp. Fluids 49, 2010, 761-773.

[19] A. Stangierska, J. Zabielska-Matejuk, A. Skrzypczak, A. Kropacz, W. Przybylska, Przemysl Chemiczny 89 (2010) 1509-1512.

[20] Y. Zhang, H. Gao, Y. Guo, Y.-H. Joo, J. M. Shreeve, Chem. Eur. J. (2010) 3114-3120.

[21] I. S. Arvanitoyannis, A. Kassaveti, Fish waste management: Treatment methods and potential uses of treated waste, in: Waste Management for the Food Industries, Academic Press, Amsterdam, 2008, pp. 861-937.

[22] I. Eide-Haugmo, O. G. Brakstad, K. A. Hoff, K. R. Sørheim, E. F. da Silva, H. F. Svendsen, Energy Procedia 1 (2009) 1297-1304, Greenhouse Gas Control Technologies 9, Proceedings of the 9th International Conference on Greenhouse Gas Control Technologies (GHGT-9), 16-20 November 2008, Washington DC, USA.

[23] J. J. P. Mark, A. Kumar, H. Demattio, W. Hoffmann, A. Malik, F. M. Matysik, Electroanalysis 23 (2011) 161-168.

[24] C. F. Cullis, B. A. Khokhar, Combust. Flame 4 (1960) 265-269.

[25] P. Gray, J. C. J. Thynne, Proc. Combust. Inst. 10 (1965) 435-443.

[26] F. Moore, C. F. H. Tipper, Combust. Flame 19 (1972) 81-87.

[27] C. F. H. Tipper, A. Titchard, Combust. Flame 16 (1971) 223-232.

[28] P. W. Jones, K. Selby, M. J. Tidball, D. J. Waddington, Combust. Flame 22 (1974) 209217.

[29] R. Atkinson, J. N. Pitts, Jr., J. Chem. Phys. 68 (1978) 911-915.

[30] I. R. Slagle, J. F. Dudich, D. Gutman, Chem. Phys. Lett. 61 (1979) 620-624.

[31] X. Ge, A. S. Wexler, S. L. Clegg, Atmos. Environ. 45 (2011) 524-546.

[32] X. Ge, A. S. Wexler, S. L. Clegg, Atmos. Environ. 45 (2011) 561-577.

[33] L. Yang, Z. Chen, J. Shen, Z. Xu, H. Liang, J. Tian, Y. Ben, X. Zhai, W. Shi, G. Li, Environ. Sci. Technol. 43 (2009) 5481-5487. 
[34] J. Wang, M. Chaos, B. Yang, T. A. Cool, F. L. Dryer, T. Kasper, P. Oßwald, K. KohseHöinghaus, P. R. Westmoreland, Phys. Chem. Chem. Phys. 11 (2009) 1328-1339.

[35] T. S. Kasper, P. Oßwald, M. Kamphus, K. Kohse-Höinghaus, Combust. Flame 150 (2007) 220-231.

[36] J. Wang, U. Struckmeier, B. Yang, T. A. Cool, P. Oßwald, K. Kohse-Höinghaus, T. Kasper, N. Hansen, P. R. Westmoreland, J. Phys. Chem. A 112 (2008) 9255-9265.

[37] U. Struckmeier, P. Oßwald, T. Kasper, L. Böhling, M. Heusing, M. Köhler, A. Brockhinke, K. Kohse-Höinghaus, Z. Phys. Chem. 223 (2009) 503-537.

[38] J. A. Montgomery, Jr., M. J. Frisch, J.W. Ochterski, G. A. Petersson, J. Chem. Phys. 110 (1999) 2822-2827.

[39] M. J. Frisch, G. W. Trucks, H. B. Schlegel, G. E. Scuseria, M. A. Robb, J. R. Cheeseman, G. Scalmani, V. Barone, B. Mennucci, G. A. Petersson, H. Nakatsuji, M. Caricato, X. Li, H. P. Hratchian, A. F. Izmaylov, J. Bloino, G. Zheng, J. L. Sonnenberg, M. Hada, M. Ehara, K. Toyota, R. Fukuda, J. Hasegawa, M. Ishida, T. Nakajima, Y. Honda, O. Kitao, H. Nakai, T. Vreven, J. A. Montgomery, Jr., J. E. Peralta, F. Ogliaro, M. Bearpark, J. J. Heyd, E. Brothers, K. N. Kudin, V. N. Staroverov, R. Kobayashi, J. Normand, K. Raghavachari, A. Rendell, J. C. Burant, S. S. Iyengar, J. Tomasi, M. Cossi, N. Rega, J. M. Millam, M. Klene, J. E. Knox, J. B. Cross, V. Bakken, C. Adamo, J. Jaramillo, R. Gomperts, R. E. Stratmann, O.Yazyev, A. J. Austin, R. Cammi, C. Pomelli, J. W. Ochterski, R. L. Martin, K. Morokuma, V. G. Zakrzewski, G. A. Voth, P. Salvador, J. J. Dannenberg, S. Dapprich, A. D. Daniels, Ö. Farkas, J. B. Foresman, J. V. Ortiz, J. Cioslowski, D. J. Fox, Gaussian 09 revision B.01, Gaussian, Inc., Wallingford, CT, 2009.

[40] P. Y. Ayala, H. B. Schlegel, J. Chem. Phys. 108 (1998) 2314-2325.

[41] A. Bodi, J. P. Kercher, C. Bond, P. Meteesatien, B. Sztáray, T. Baer, J. Phys. Chem. A 110 (2006) 13425-13433. 
[42] X. An, M. Mansson, J. Chem. Thermodyn. 15 (1983) 287-293.

[43] E. Goos, A. Burcat, B. Ruscic. Third Millennium Thermodynamic Database for Combustion and Air-Pollution Use with Updates from Active Thermochemical Tables; ftp://ftp.technion.ac.il/pub/supported/aetdd/thermodynamics, accessed August 2011.

[44] D. A. Hrovat, E. E. Waali, W. T. Borden, J. Am. Chem. Soc. 114 (1992) 8698-8699.

[45] J. R. Barker, N. F. Ortiz, J. M. Preses, L. L. Lohr, A. Maranzana, P. J. Stimac, L. T. Nguyen, T. J. D. Kumar, University of Michigan, Ann Arbor, MI, 2011, http://aossresearch.engin.umich.edu/multiwell/.

[46] J. R. Barker, Int. J. Chem. Kinet. 33 (2001) 232-245.

[47] J. R. Barker, Int. J. Chem. Kinet. 41 (2009) 748-763.

[48] S. Lago, B. Garzón, S. Calero, C. Vega, J. Phys. Chem. B 101 (1997) 6763-6771.

[49] A. Burcat and B. Ruscic. Third Millenium Ideal Gas and Condensed Phase Thermochemical Database for Combustion with Updates from Active Chemical Tables. Technical Report Report TAE 960 and ANL-05/20, Technion-IIT, Haifa, and Argonne National Laboratory, Argonne, Illinois, 2005.

[50] J. B. Pedley. Thermochemical Data and Structures of Organic Compounds; Thermodynamics Research Center, Texas A\&M University: College Station, Texas, 1994.

[51] H. Y. Afeefy, J. F. Liebman, S. E. Stein, "Neutral Thermochemical Data" in NIST Chemistry WebBook, NIST Standard Reference Database Number 69, P. J. Linstrom, W. G. Mallard (eds.), National Institute of Standards and Technology, Gaithersburg MD, 20899, http://webbook.nist.gov.

[52] W. T. Borden, University of North Texas, borden@unt.edu, personal communication, 2011.

[53] A. Doughty, G. B. Bacskay, J. C. Mackie, J. Phys. Chem. 98 (1994) 13546-13555. 
[54] R. J. Kee, F. M. Rupley, J. A. Miller, M. E. Coltrin, J. F. Grcar, E. Meeks, et al. CHEMKIN release 4.1.1. San Diego, CA: Reaction Design (2007).

[55] P. Glarborg, M. U. Alzueta, K. Dam-Johansen, J. A. Miller, Combust. Flame 115 (1998) 1-27.

[56] C. L. Rasmussen, J. G. Jakobsen, P. Glarborg, Int. J. Chem. Kinet. 40 (2008) 778-807.

[57] Ø. Skreiberg, P. Kilpinen, P. Glarborg, Combust. Flame 136 (2004) 501-518.

[58] C. L. Rasmussen, A. E. Rasmussen, P. Glarborg, Combust. Flame 154 (2008) 529-545.

[59] T. Mendiara, P. Glarborg, Energy Fuels 23 (2009) 3565-3572.

[60] A. A. Konnov, Combust. Flame 156 (2009) 2093-2105.

[61] A. M. Dean, J. W. Bozzelli, in: W. C. Gardiner, Jr. (ed.), Gas-Phase Combustion Chemistry, Springer-Verlag, New York, 2000, p. 125-342 (Chapter 2: Combustion Chemistry of Nitrogen).

[62] S. A. Carl, J. N. Crowley, J. Phys. Chem. A 102 (1998) 8131-8141.

[63] A. Galano, R. Alvarez-Idaboy, J. Chem. Theory Comput. 4 (2008) 322-327.

[64] N. M. Marinov, Int. J. Chem. Kinet. 31 (1999) 183-220.

[65] W. Tsang, J. Phys. Chem. Ref. Data 17 (1988) 887-951.

[66] M. Demissy, R. Lesclaux, Int. J. Chem. Kinet. 14 (1982) 1-12.

[67] P. V. Khe, R. Lesclaux, J. Phys. Chem. 83 (1979) 1119-1122.

[68] L. V. Moskaleva, M. C. Lin, J. Phys. Chem. A 102 (1998) 4687-4693.

[69] B. Wang, H. Hou, Y. Gu, J. Phys. Chem. A 105 (2001) 156-164.

[70] K. Sendt, E. Ikeda, G. B. Bacskay, J. C. Mackie, J. Phys. Chem. A 103 (1999) 10541072.

[71] J. Sun, Y. Tang, X. Jia, F. Wang, H. Sun, J. Feng, X. Pan, L. Hao, R. Wang, J. Chem. Phys. 132 (2010) 064301.

[72] K. Hoyermann, J. Seeba, Z. Phys. Chem. 188 (1995) 215-226.

[73] T. Kakumoto, K. Saito, A. Imamura, J. Phys. Chem. 89 (1985) 2286-2291. 
[74] E. A. Syrstad, F. Turecek, J. Phys. Chem. A 105 (2001) 11144-11155.

[75] J. C. Boden, R. A. Back, Trans. Faraday Soc. 66 (1970) 175-182.

[76] R. A. Back, T. Yokota, Int. J. Chem. Kinet. 5 (1973) 37-46.

[77] C. R. C. Lindley, J. G. Calvert, J. H. Shaw, Chem. Phys. Lett. 67 (1979) 57-62.

[78] J. Seetula, K. Kalliorinne, J. Koskikallio, J. Photochem. Photobiol. A 43 (1988) 31-41.

[79] R. Atkinson, R. A. Perry, J. N. Pitts, Jr., J. Chem. Phys. 68 (1978) 1850-1853.

[80] W. Hack, H. Schacke, M. Schröter, H. Gg. Wagner, Proc. Combust. Inst. 17 (1979) 505513.

[81] S. R. Bosco, D. F. Nava, W. D. Brobst, L. J. Stief, J. Chem. Phys. 81 (1984) 3505-3511.

[82] A. Lucassen, P. Oßwald, U. Struckmeier, K. Kohse-Höinghaus, T. Kasper, N. Hansen, T. A. Cool, P. R. Westmoreland, Proc. Combust. Inst. 32 (2009) 1269-1276.

[83] A. Frassoldati, T. Faravello, E. Ranzi, K. Kohse-Höinghaus, P. R. Westmoreland, Combust. Flame 158 (2011) 1264-1276.

[84] T. Kasper, Molekularstrahlmassenspektrometrie zur Analytik in Flammen oxygenierter Brennstoffe, PhD thesis, Bielefeld University, 2006 (in German).

[85] W. Li, M. E. Law, P. R. Westmoreland, T. Kasper, N. Hansen, K. Kohse-Höinghaus, Combust. Flame 158 (2011) 2077-2089.

[86] K. Kohse-Höinghaus, P. Oßwald, T. A. Cool, T. Kasper, N. Hansen, F. Qi, C. K. Westbrook, P. R. Westmoreland, Angew. Chem. Int. Ed. 49 (2010) 3572-3597.

[87] G. Fontaras, G. Karavalakis, M. Kousoulidou, L. Ntziachristos, E. Bakeas, S. Stournas, Z. Samaras, Env. Pollut. 158 (2010) 2496-2503.

[88] L. G. Anderson, Energy Environ. Sci.2 (2009) 1015-1037.

[89] B. A. Williams, J. W. Fleming, Combust. Flame 110 (1997) 1-13.

[90] J. O. L. Wendt, C. V. Sternling, J. Air Pollut. Control Assoc. 24 (1974) 1055-1058. 
App. A. $\mathrm{CH}_{3} \mathrm{CH}_{2} \mathrm{NH}_{2}$ subset of the reaction mechanism. Rate constants are listed in the form

$A \mathrm{~T}^{\mathrm{n}} \exp \left(-\mathrm{E}_{\mathrm{a}} / \mathrm{RT}\right)$. Units are calories, $\mathrm{cm}^{3}$, mol, second.

\begin{tabular}{|c|c|c|c|c|c|}
\hline \multicolumn{2}{|r|}{ Reaction Mechanism } & \multirow{2}{*}{$\begin{array}{c}\mathrm{A} \\
6.2 \mathrm{E} 67\end{array}$} & \multirow{2}{*}{$\begin{array}{c}\mathrm{N} \\
-15.944\end{array}$} & \multirow{2}{*}{\begin{tabular}{|c|}
$E_{a}$ \\
99348
\end{tabular}} & \multirow{2}{*}{\begin{tabular}{|l|} 
Source \\
$\mathrm{pw}^{\mathrm{a}}$ \\
\end{tabular}} \\
\hline 1. & $\mathrm{CH}_{3} \mathrm{CH}_{2} \mathrm{NH}_{2}=\mathrm{C}_{2} \mathrm{H}_{4}+\mathrm{NH}_{3}$ & & & & \\
\hline 2. & $\mathrm{C}_{2} \mathrm{H}_{5}+\mathrm{NH}_{2}(+\mathrm{M})=\mathrm{CH}_{3} \mathrm{CH}_{2} \mathrm{NH}_{2}(+\mathrm{M})$ & $7.2 \mathrm{E} 12$ & 0.420 & 0 & $\mathrm{k}_{\mathrm{CH} 3+\mathrm{NH} 2,[66]}$ \\
\hline & Low pressure limit & $2.2 \mathrm{E} 30$ & -3.850 & 0 & \\
\hline 3. & $\mathrm{CH}_{3} \mathrm{CHNH}_{2}+\mathrm{H}=\mathrm{CH}_{3} \mathrm{CH}_{2} \mathrm{NH}_{2}$ & $1.7 \mathrm{E} 13$ & 0.220 & 0 & $\mathrm{k}_{\mathrm{i}-\mathrm{C} 3 \mathrm{H} 7+\mathrm{H}}$ \\
\hline 4. & $\mathrm{CH}_{2} \mathrm{CH}_{2} \mathrm{NH}_{2}+\mathrm{H}=\mathrm{CH}_{3} \mathrm{CH}_{2} \mathrm{NH}_{2}$ & $5.4 \mathrm{E} 13$ & 0.160 & 0 & $\mathrm{k}_{\mathrm{C} 2 \mathrm{H} 5+\mathrm{H}}$ \\
\hline 5. & $\mathrm{CH}_{3} \mathrm{CH}_{2} \mathrm{NH}_{2}+\mathrm{H}=\mathrm{CH}_{2} \mathrm{CH}_{2} \mathrm{NH}_{2}+\mathrm{H}_{2}$ & $1.2 \mathrm{E} 07$ & 1.800 & 5100 & $\mathrm{k}_{\mathrm{C} 2 \mathrm{H} 5 \mathrm{OH}+\mathrm{H}}$ \\
\hline 6. & $\mathrm{CH}_{3} \mathrm{CH}_{2} \mathrm{NH}_{2}+\mathrm{H}=\mathrm{CH}_{3} \mathrm{CHNH}_{2}+\mathrm{H}_{2}$ & $2.6 \mathrm{E} 07$ & 1.650 & 2830 & $\mathrm{k}_{\mathrm{C} 2 \mathrm{H} 5 \mathrm{OH}+\mathrm{H}}$ \\
\hline 7. & $\mathrm{CH}_{3} \mathrm{CH}_{2} \mathrm{NH}_{2}+\mathrm{H}=\mathrm{CH}_{3} \mathrm{CH}_{2} \mathrm{NH}+\mathrm{H}_{2}$ & 4.8E08 & 1.500 & 9700 & $\mathrm{k}_{\mathrm{CH} 3 \mathrm{NH} 2+\mathrm{H}}$ \\
\hline 8. & $\mathrm{CH}_{3} \mathrm{CH}_{2} \mathrm{NH}_{2}+\mathrm{O}=\mathrm{CH}_{2} \mathrm{CH}_{2} \mathrm{NH}_{2}+\mathrm{OH}$ & 9.4E07 & 1.700 & 5460 & $\mathrm{k}_{\mathrm{C} 2 \mathrm{H} 5 \mathrm{OH}+\mathrm{O}}$ \\
\hline 9. & $\mathrm{CH}_{3} \mathrm{CH}_{2} \mathrm{NH}_{2}+\mathrm{O}=\mathrm{CH}_{3} \mathrm{CHNH}_{2}+\mathrm{OH}$ & $6.8 \mathrm{E} 12$ & 0.000 & 1275 & {$[29]$} \\
\hline 10. & $\mathrm{CH}_{3} \mathrm{CH}_{2} \mathrm{NH}_{2}+\mathrm{O}=\mathrm{CH}_{3} \mathrm{CH}_{2} \mathrm{NH}+\mathrm{OH}$ & 3.3E08 & 1.500 & 6348 & $\mathrm{k}_{\mathrm{CH} 3 \mathrm{NH} 2+\mathrm{O}}$ \\
\hline 11. & $\mathrm{CH}_{3} \mathrm{CH}_{2} \mathrm{NH}_{2}+\mathrm{OH}=\mathrm{CH}_{2} \mathrm{CH}_{2} \mathrm{NH}_{2}+\mathrm{H}_{2} \mathrm{O}$ & $1.6 \mathrm{E} 12$ & 0.000 & 1300 & $\mathrm{k}_{\mathrm{C} 2 \mathrm{H} 5 \mathrm{OH}+\mathrm{OH}}$ \\
\hline 12. & $\mathrm{CH}_{3} \mathrm{CH}_{2} \mathrm{NH}_{2}+\mathrm{OH}=\mathrm{CH}_{3} \mathrm{CHNH}_{2}+\mathrm{H}_{2} \mathrm{O}$ & $1.4 \mathrm{E} 13$ & 0.000 & 0 & {$[62]$} \\
\hline 13. & $\mathrm{CH}_{3} \mathrm{CH}_{2} \mathrm{NH}_{2}+\mathrm{OH}=\mathrm{CH}_{3} \mathrm{CH}_{2} \mathrm{NH}+\mathrm{H}_{2} \mathrm{O}$ & $2.4 \mathrm{E} 06$ & 2.000 & 447 & $\mathrm{k}_{\mathrm{CH} 3 \mathrm{NH} 2+\mathrm{OH}}$ \\
\hline 14. & $\mathrm{CH}_{3} \mathrm{CH}_{2} \mathrm{NH}_{2}+\mathrm{HO}_{2}=\mathrm{CH}_{2} \mathrm{CH}_{2} \mathrm{NH}_{2}+\mathrm{H}_{2} \mathrm{O}_{2}$ & $1.2 \mathrm{E} 04$ & 2.550 & 15750 & $\mathrm{k}_{\mathrm{C} 2 \mathrm{H} 5 \mathrm{OH}+\mathrm{HO} 2}$ \\
\hline 15. & $\mathrm{CH}_{3} \mathrm{CH}_{2} \mathrm{NH}_{2}+\mathrm{HO}_{2}=\mathrm{CH}_{3} \mathrm{CHNH}_{2}+\mathrm{H}_{2} \mathrm{O}_{2}$ & $8.2 \mathrm{E} 03$ & 2.550 & 10750 & $\mathrm{k}_{\mathrm{C} 2 \mathrm{H} 5 \mathrm{OH}+\mathrm{HO} 2}$ \\
\hline 16. & $\mathrm{CH}_{3} \mathrm{CH}_{2} \mathrm{NH}_{2}+\mathrm{CH}_{3}=\mathrm{CH}_{2} \mathrm{CH}_{2} \mathrm{NH}_{2}+\mathrm{CH}_{4}$ & $2.2 \mathrm{E} 02$ & 3.180 & 9620 & $\mathrm{k}_{\mathrm{C} 2 \mathrm{H} 5 \mathrm{OH}+\mathrm{CH} 3}$ \\
\hline 17. & $\mathrm{CH}_{3} \mathrm{CH}_{2} \mathrm{NH}_{2}+\mathrm{CH}_{3}=\mathrm{CH}_{3} \mathrm{CHNH}_{2}+\mathrm{CH}_{4}$ & $7.3 \mathrm{E} 02$ & 2.990 & 7950 & $\mathrm{k}_{\mathrm{C} 2 \mathrm{H} 5 \mathrm{OH}+\mathrm{CH} 3}$ \\
\hline 18. & $\mathrm{CH}_{3} \mathrm{CH}_{2} \mathrm{NH}_{2}+\mathrm{CH}_{3}=\mathrm{CH}_{3} \mathrm{CH}_{2} \mathrm{NH}+\mathrm{CH}_{4}$ & $1.6 \mathrm{E} 06$ & 1.870 & 8842 & $\mathrm{k}_{\mathrm{CH} 3 \mathrm{NH} 2+\mathrm{CH} 3}$ \\
\hline 19. & $\mathrm{CH}_{3} \mathrm{CH}_{2} \mathrm{NH}_{2}+\mathrm{NH}_{2}=\mathrm{CH}_{2} \mathrm{CH}_{2} \mathrm{NH}_{2}+\mathrm{NH}_{3}$ & $2.2 \mathrm{E} 02$ & 3.180 & 9620 & $\mathrm{k}_{\mathrm{C} 2 \mathrm{H} 5 \mathrm{OH}+\mathrm{CH} 3}$ \\
\hline 20. & $\mathrm{CH}_{3} \mathrm{CH}_{2} \mathrm{NH}_{2}+\mathrm{NH}_{2}=\mathrm{CH}_{3} \mathrm{CHNH}_{2}+\mathrm{NH}_{3}$ & 7.3E02 & 2.990 & 7950 & $\mathrm{k}_{\mathrm{C} 2 \mathrm{H} 5 \mathrm{OH}+\mathrm{CH} 3}$ \\
\hline 21. & $\mathrm{CH}_{3} \mathrm{CH}_{2} \mathrm{NH}_{2}+\mathrm{NH}_{2}=\mathrm{CH}_{3} \mathrm{CH}_{2} \mathrm{NH}+\mathrm{NH}_{3}$ & $1.8 \mathrm{E} 06$ & 1.940 & 7143 & $\mathrm{k}_{\mathrm{CH} 3 \mathrm{NH} 2+\mathrm{NH} 2}$ \\
\hline 22. & $\mathrm{C}_{2} \mathrm{H}_{4}+\mathrm{NH}_{2}=\mathrm{CH}_{2} \mathrm{CH}_{2} \mathrm{NH}_{2}$ & $1.2 \mathrm{E} 11$ & 0.000 & 3955 & [67] \\
\hline 23. & $\mathrm{CH}_{2} \mathrm{CH}_{2} \mathrm{NH}_{2}+\mathrm{H}=\mathrm{CH}_{2} \mathrm{CHNH}_{2}+\mathrm{H}_{2}$ & $1.8 \mathrm{E} 12$ & 0.000 & 0 & $\mathrm{k}_{\mathrm{n}-\mathrm{C} 3 \mathrm{H} 7+\mathrm{H}}$ \\
\hline 24. & $\mathrm{CH}_{2} \mathrm{CH}_{2} \mathrm{NH}_{2}+\mathrm{O}=\mathrm{CH}_{2} \mathrm{O}+\mathrm{CH}_{2} \mathrm{NH}_{2}$ & $9.6 \mathrm{E} 13$ & 0.000 & 0 & $\mathrm{k}_{\mathrm{n}-\mathrm{C} 3 \mathrm{H} 7+\mathrm{O}}$ \\
\hline 25. & $\mathrm{CH}_{2} \mathrm{CH}_{2} \mathrm{NH}_{2}+\mathrm{OH}=\mathrm{CH}_{2} \mathrm{CHNH}_{2}+\mathrm{H}_{2} \mathrm{O}$ & $2.4 \mathrm{E} 13$ & 0.000 & 0 & $\mathrm{k}_{\mathrm{n}-\mathrm{C} 3 \mathrm{H} 7+\mathrm{OH}}$ \\
\hline 26. & $\mathrm{CH}_{2} \mathrm{CH}_{2} \mathrm{NH}_{2}+\mathrm{HO}_{2}=>\mathrm{CH}_{2} \mathrm{O}+\mathrm{OH}+\mathrm{CH}_{2} \mathrm{NH}_{2}$ & $2.4 \mathrm{E} 13$ & 0.000 & 0 & $\mathrm{k}_{\mathrm{n}-\mathrm{C} 3 \mathrm{H} 7+\mathrm{HO} 2}$ \\
\hline 27. & $\mathrm{CH}_{2} \mathrm{CH}_{2} \mathrm{NH}_{2}+\mathrm{O}_{2}=\mathrm{CH}_{2} \mathrm{CHNH}_{2}+\mathrm{HO}_{2}$ & $3.7 \mathrm{E} 16$ & -1.630 & 3418 & $\mathrm{k}_{\mathrm{n}-\mathrm{C} 3 \mathrm{H} 7+\mathrm{O} 2}$ \\
\hline 28. & $\mathrm{CH}_{2} \mathrm{CH}_{2} \mathrm{NH}_{2}+\mathrm{HCO}=\mathrm{CH}_{3} \mathrm{CH}_{2} \mathrm{NH}_{2}+\mathrm{CO}$ & $6.0 \mathrm{E} 13$ & 0.000 & 0 & $\mathrm{k}_{\mathrm{n}-\mathrm{C} 3 \mathrm{H} 7+\mathrm{HCO}}$ \\
\hline 29. & $\mathrm{CH}_{2} \mathrm{CH}_{2} \mathrm{NH}_{2}+\mathrm{CH}_{3}=\mathrm{CH}_{2} \mathrm{CHNH}_{2}+\mathrm{CH}_{4}$ & $1.2 \mathrm{E} 13$ & -0.320 & 0 & $\mathrm{k}_{\mathrm{n}-\mathrm{C} 3 \mathrm{H} 7+\mathrm{CH} 3}$ \\
\hline 30. & $\mathrm{CH}_{2} \mathrm{CHNH}_{2}+\mathrm{H}(+\mathrm{M})=\mathrm{CH}_{3} \mathrm{CHNH}_{2}(+\mathrm{M})$ & $1.4 \mathrm{E} 09$ & 1.463 & 1355 & $\mathrm{k}_{\mathrm{C} 2 \mathrm{H} 4+\mathrm{H}(+\mathrm{M})}$ \\
\hline & Low pressure limit & $2.0 \mathrm{E} 39$ & -6.642 & 5769 & \\
\hline & TROE /-0.569 2999147 152.4/ & & & & \\
\hline 31. & $\mathrm{CH}_{3} \mathrm{CHNH}_{2}=\mathrm{CH}_{3} \mathrm{CHNH}+\mathrm{H}$ & $1.1 \mathrm{E} 45$ & -10.24 & 47817 & $\mathrm{k}_{\mathrm{CH} 2 \mathrm{NH} 2}$ \\
\hline 32. & $\mathrm{CH}_{3} \mathrm{CHNH}_{2}+\mathrm{H}=\mathrm{CH}_{2} \mathrm{CHNH}_{2}+\mathrm{H}_{2}$ & 4.9E08 & 1.700 & 588 & $\mathrm{k}_{\mathrm{CH} 3 \mathrm{CHOH}+\mathrm{H}}$ \\
\hline 33. & $\mathrm{CH}_{3} \mathrm{CHNH}_{2}+\mathrm{H}=\mathrm{CH}_{3}+\mathrm{CH}_{2} \mathrm{NH}_{2}$ & $8.4 \mathrm{E} 16$ & -0.891 & 203 & $\mathrm{k}_{\mathrm{CH} 3 \mathrm{CHOH}+\mathrm{H}}$ \\
\hline 34. & $\mathrm{CH}_{3} \mathrm{CHNH}_{2}+\mathrm{H}=\mathrm{C}_{2} \mathrm{H}_{4}+\mathrm{NH}_{3}$ & 4.7E21 & -3.020 & 2845 & $\mathrm{k}_{\mathrm{CH} 3 \mathrm{CHOH}+\mathrm{H}}$ \\
\hline 35. & $\mathrm{CH}_{3} \mathrm{CHNH}_{2}+\mathrm{H}=\mathrm{C}_{2} \mathrm{H}_{5}+\mathrm{NH}_{2}$ & $2.0 \mathrm{E} 13$ & 0.000 & 0 & $\mathrm{k}_{\mathrm{i}-\mathrm{C} 3 \mathrm{H} 7+\mathrm{H}}$ \\
\hline 36. & $\mathrm{CH}_{3} \mathrm{CHNH}_{2}+\mathrm{O}=\mathrm{CH}_{3}+\mathrm{H}_{2} \mathrm{NCHO}$ & $4.0 \mathrm{E} 13$ & 0.000 & 0 & $\mathrm{k}_{\mathrm{i}-\mathrm{C} 3 \mathrm{H} 7+\mathrm{O}}$ \\
\hline 36. & $\mathrm{CH}_{3} \mathrm{CHNH}_{2}+\mathrm{O}=\mathrm{CH}_{2} \mathrm{CHNH}_{2}+\mathrm{OH}$ & $2.5 \mathrm{E} 13$ & 0.000 & 0 & $\mathrm{k}_{\mathrm{i}-\mathrm{C} 3 \mathrm{H} 7+\mathrm{O}}$ \\
\hline 37. & $\mathrm{CH}_{3} \mathrm{CHNH}_{2}+\mathrm{OH}=\mathrm{CH}_{2} \mathrm{CHNH}_{2}+\mathrm{H}_{2} \mathrm{O}$ & $2.4 \mathrm{E} 13$ & 0.000 & 0 & $\mathrm{k}_{\mathrm{i}-\mathrm{C} 3 \mathrm{H} 7+\mathrm{OH}}$ \\
\hline 38. & $\mathrm{CH}_{3} \mathrm{CHNH}_{2}+\mathrm{HO}_{2}=\mathrm{CH}_{3}+\mathrm{OH}+\mathrm{H}_{2} \mathrm{NCHO}$ & $2.4 \mathrm{E} 13$ & 0.000 & 0 & $\mathrm{k}_{\mathrm{i}-\mathrm{C} 3 \mathrm{H} 7+\mathrm{HO} 2}$ \\
\hline 39. & $\mathrm{CH}_{3} \mathrm{CHNH}_{2}+\mathrm{O}_{2}=\mathrm{CH}_{2} \mathrm{CHNH}_{2}+\mathrm{HO}_{2}$ & $6.7 \mathrm{E} 20$ & -3.020 & 2504 & $\mathrm{k}_{\mathrm{i}-\mathrm{C} 3 \mathrm{H} 7+\mathrm{O} 2}$ \\
\hline 40. & $\mathrm{CH}_{3} \mathrm{CHNH}_{2}+\mathrm{HCO}=\mathrm{CH}_{3} \mathrm{CH}_{2} \mathrm{NH}_{2}+\mathrm{CO}$ & $1.2 \mathrm{E} 14$ & 0.000 & 0 & $\mathrm{k}_{\mathrm{i}-\mathrm{C} 3 \mathrm{H} 7+\mathrm{HCO}}$ \\
\hline
\end{tabular}




\begin{tabular}{|c|c|c|c|c|c|}
\hline 41. & $\mathrm{CH}_{3} \mathrm{CHNH}_{2}+\mathrm{CH}_{3}=\mathrm{CH}_{2} \mathrm{CHNH}_{2}+\mathrm{CH}_{4}$ & $1.8 \mathrm{E} 13$ & 0.000 & -769 & $\mathrm{k}_{\mathrm{i}-\mathrm{C} 3 \mathrm{H} 7+\mathrm{CH} 3}$ \\
\hline 42. & $\mathrm{CH}_{3} \mathrm{CH}_{2} \mathrm{NH}=\mathrm{CH}_{2} \mathrm{NH}+\mathrm{CH}_{3}$ & $1.9 \mathrm{E} 10$ & 0.000 & 23500 & $\mathrm{k}_{\mathrm{CH} 3 \mathrm{CH} 2 \mathrm{O}}, \mathrm{E}_{\mathrm{a}}$ adj. \\
\hline 43. & $\mathrm{CH}_{3} \mathrm{CH}_{2} \mathrm{NH}=\mathrm{CH}_{3} \mathrm{CHNH}+\mathrm{H}$ & $1.6 \mathrm{E} 36$ & -7.920 & 36342 & $\mathrm{k}_{\mathrm{CH} 3 \mathrm{NH}}$ \\
\hline 44. & $\mathrm{CH}_{3} \mathrm{CH}_{2} \mathrm{NH}+\mathrm{H}=\mathrm{CH}_{3}+\mathrm{CH}_{2} \mathrm{NH}_{2}$ & $1.4 \mathrm{E} 12$ & 0.701 & 346 & $\mathrm{k}_{\mathrm{CH} 3 \mathrm{CH} 2 \mathrm{O}+\mathrm{H}}$ \\
\hline 45. & $\mathrm{CH}_{3} \mathrm{CH}_{2} \mathrm{NH}+\mathrm{H}=\mathrm{CH}_{3} \mathrm{CHNH}+\mathrm{H}_{2}$ & $7.2 \mathrm{E} 08$ & 1.500 & -894 & $\mathrm{k}_{\mathrm{CH} 3 \mathrm{NH}+\mathrm{H}}$ \\
\hline 46. & $\mathrm{CH}_{3} \mathrm{CH}_{2} \mathrm{NH}+\mathrm{O}=\mathrm{CH}_{3} \mathrm{CHNH}+\mathrm{OH}$ & $5.0 \mathrm{E} 08$ & 1.500 & -894 & $\mathrm{k}_{\mathrm{CH} 3 \mathrm{NH}+\mathrm{O}}$ \\
\hline 47. & $\mathrm{CH}_{3} \mathrm{CH}_{2} \mathrm{NH}+\mathrm{OH}=\mathrm{CH}_{3} \mathrm{CHNH}+\mathrm{H}_{2} \mathrm{O}$ & $3.6 \mathrm{E} 06$ & 2.000 & -1192 & $\mathrm{k}_{\mathrm{CH} 3 \mathrm{NH}+\mathrm{OH}}$ \\
\hline 48. & $\mathrm{CH}_{3} \mathrm{CH}_{2} \mathrm{NH}+\mathrm{CH}_{3}=\mathrm{CH}_{3} \mathrm{CHNH}+\mathrm{CH}_{4}$ & $2.4 \mathrm{E} 06$ & 1.870 & -1113 & $\mathrm{k}_{\mathrm{CH} 3 \mathrm{NH}+\mathrm{CH} 3}$ \\
\hline \multirow[t]{3}{*}{49.} & $\mathrm{CHCHNH}_{2}+\mathrm{H}(+\mathrm{M})=\mathrm{CH}_{2} \mathrm{CHNH}_{2}(+\mathrm{M})$ & $3.9 \mathrm{E} 13$ & 0.200 & 0 & $\mathrm{k}_{\mathrm{C} 2 \mathrm{H} 3+\mathrm{H}(+\mathrm{M})}$ \\
\hline & Low pressure limit & $2.1 \mathrm{E} 24$ & -1.300 & 0 & \\
\hline & TROE /0.5 1E-30 1E30 1E30/ & & & & \\
\hline \multirow[t]{3}{*}{50.} & $\mathrm{CH}_{2} \mathrm{CNH}_{2}+\mathrm{H}(+\mathrm{M})=\mathrm{CH}_{2} \mathrm{CHNH}_{2}(+\mathrm{M})$ & 3.9E13 & 0.200 & 0 & $\mathrm{k}_{\mathrm{C} 2 \mathrm{H} 3+\mathrm{H}(+\mathrm{M})}$ \\
\hline & Low pressure limit & $2.1 \mathrm{E} 24$ & -1.300 & 0 & \\
\hline & TROE /0.5 1E-30 1E30 1E30/ & & & & \\
\hline 51. & $\mathrm{CH}_{2} \mathrm{CHNH}_{2}+\mathrm{H}=\mathrm{CHCHNH}_{2}+\mathrm{H}_{2}$ & $2.4 \mathrm{E} 02$ & 3.630 & 11266 & $\mathrm{k}_{\mathrm{C} 2 \mathrm{H} 4+\mathrm{H}}$ \\
\hline 52. & $\mathrm{CH}_{2} \mathrm{CHNH}_{2}+\mathrm{H}=\mathrm{CH}_{2} \mathrm{CNH}_{2}+\mathrm{H}_{2}$ & $2.4 \mathrm{E} 02$ & 3.630 & 11266 & $\mathrm{k}_{\mathrm{C} 2 \mathrm{H} 4+\mathrm{H}}$ \\
\hline 53. & $\mathrm{CH}_{2} \mathrm{CHNH}_{2}+\mathrm{H}=\mathrm{CH}_{2} \mathrm{CHNH}+\mathrm{H}_{2}$ & $4.8 \mathrm{E} 08$ & 1.500 & 9700 & $\mathrm{k}_{\mathrm{CH} 3 \mathrm{NH} 2+\mathrm{H}}$ \\
\hline \multirow[t]{3}{*}{54.} & $\mathrm{CH}_{2} \mathrm{CHNH}_{2}+\mathrm{O}=\mathrm{CH}_{3}+\mathrm{H}_{2} \mathrm{NCO}$ & 3.9E12 & 0.000 & 1494 & $\mathrm{k}_{\mathrm{C} 2 \mathrm{H} 4+\mathrm{O}}$ \\
\hline & & $6.2 \mathrm{E} 13$ & 0.000 & 6855 & \\
\hline & Duplicate reaction & & & & \\
\hline 55. & $\mathrm{CH}_{2} \mathrm{CHNH}_{2}+\mathrm{O}=\mathrm{CH}_{2} \mathrm{CHNH}+\mathrm{OH}$ & $3.3 \mathrm{E} 08$ & 1.500 & 6348 & $\mathrm{k}_{\mathrm{CH} 3 \mathrm{NH} 2+\mathrm{O}}$ \\
\hline 56. & $\mathrm{CH}_{2} \mathrm{CHNH}_{2}+\mathrm{OH}=\mathrm{CHCHNH}_{2}+\mathrm{H}_{2} \mathrm{O}$ & $1.3 \mathrm{E}-1$ & 4.200 & -860 & $\mathrm{k}_{\mathrm{C} 2 \mathrm{H} 4+\mathrm{OH}}$ \\
\hline 57. & $\mathrm{CH}_{2} \mathrm{CHNH}_{2}+\mathrm{OH}=\mathrm{CH}_{2} \mathrm{CNH}_{2}+\mathrm{H}_{2} \mathrm{O}$ & $1.3 \mathrm{E}-1$ & 4.200 & -860 & $\mathrm{k}_{\mathrm{C} 2 \mathrm{H} 4+\mathrm{OH}}$ \\
\hline 58. & $\mathrm{CH}_{2} \mathrm{CHNH}_{2}+\mathrm{OH}=\mathrm{CH}_{2} \mathrm{CHNH}+\mathrm{H}_{2} \mathrm{O}$ & $2.4 \mathrm{E} 06$ & 2.000 & 447 & $\mathrm{k}_{\mathrm{CH} 3 \mathrm{NH} 2+\mathrm{OH}}$ \\
\hline 59. & $\mathrm{CH}_{2} \mathrm{CHNH}_{2}+\mathrm{CH}_{3}=\mathrm{CHCHNH}_{2}+\mathrm{CH}_{4}$ & $6.0 \mathrm{E} 07$ & 1.560 & 16630 & $\mathrm{k}_{\mathrm{C} 2 \mathrm{H} 4+\mathrm{CH} 3}$ \\
\hline 60. & $\mathrm{CH}_{2} \mathrm{CHNH}_{2}+\mathrm{CH}_{3}=\mathrm{CH}_{2} \mathrm{CNH}_{2}+\mathrm{CH}_{4}$ & $6.0 \mathrm{E} 07$ & 1.560 & 16630 & $\mathrm{k}_{\mathrm{C} 2 \mathrm{H} 4+\mathrm{CH} 3}$ \\
\hline 61. & $\mathrm{CH}_{2} \mathrm{CHNH}_{2}+\mathrm{CH}_{3}=\mathrm{CH}_{2} \mathrm{CHNH}+\mathrm{CH}_{4}$ & $1.6 \mathrm{E} 06$ & 1.870 & 8842 & $\mathrm{k}_{\mathrm{CH} 3 \mathrm{NH} 2+\mathrm{CH} 3}$ \\
\hline 62. & $\mathrm{CH}_{2} \mathrm{CHNH}_{2}+\mathrm{NH}_{2}=\mathrm{CHCHNH}_{2}+\mathrm{NH}_{3}$ & $5.3 \mathrm{E} 12$ & 0.000 & 10274 & $\mathrm{k}_{\mathrm{C} 2 \mathrm{H} 4+\mathrm{NH} 2}$ \\
\hline 63. & $\mathrm{CH}_{2} \mathrm{CHNH}_{2}+\mathrm{NH}_{2}=\mathrm{CH}_{2} \mathrm{CNH}_{2}+\mathrm{NH}_{3}$ & $5.3 \mathrm{E} 12$ & 0.000 & 10274 & $\mathrm{k}_{\mathrm{C} 2 \mathrm{H} 4+\mathrm{NH} 2}$ \\
\hline 64. & $\mathrm{CH}_{2} \mathrm{CHNH}_{2}+\mathrm{NH}_{2}=\mathrm{CH}_{2} \mathrm{CHNH}+\mathrm{NH}_{3}$ & $1.8 \mathrm{E} 06$ & 1.940 & 7143 & $\mathrm{k}_{\mathrm{CH} 3 \mathrm{NH} 2+\mathrm{NH} 2}$ \\
\hline 65. & $\mathrm{CH}_{3}+\mathrm{HCNH}=\mathrm{CH}_{3} \mathrm{CHNH}$ & $1.8 \mathrm{E} 13$ & 0.000 & 0 & $\mathrm{k}_{\mathrm{CH} 3+\mathrm{HCO}}$ \\
\hline 66. & $\mathrm{CH}_{3} \mathrm{CHNH}=\mathrm{CH}_{2} \mathrm{CHNH}_{2}$ & $5.0 \mathrm{E} 18$ & -2.4965 & 67995 & $\mathrm{pw}^{\mathrm{a}}$ \\
\hline 67. & $\mathrm{CH}_{2} \mathrm{CHNH}+\mathrm{H}=\mathrm{CH}_{3} \mathrm{CHNH}$ & $5.8 \mathrm{E} 13$ & 0.180 & -125 & $\mathrm{k}_{\mathrm{CH} 2 \mathrm{CHCH} 2+\mathrm{H}}$ \\
\hline 68. & $\mathrm{CH}_{3} \mathrm{CHNH}+\mathrm{H}=\mathrm{CH}_{2} \mathrm{CHNH}_{2}+\mathrm{H}$ & $3.0 \mathrm{E} 13$ & 0.000 & 0 & est. \\
\hline 69. & $\mathrm{CH}_{3} \mathrm{CHNH}+\mathrm{H}=\mathrm{CH}_{3} \mathrm{CNH}+\mathrm{H}_{2}$ & $4.7 \mathrm{E} 13$ & -0.350 & 3000 & $\mathrm{k}_{\mathrm{CH} 3 \mathrm{HCO}+\mathrm{H}}$ \\
\hline 70. & $\mathrm{CH}_{3} \mathrm{CHNH}+\mathrm{H}=\mathrm{CH}_{2} \mathrm{CHNH}+\mathrm{H}_{2}$ & $1.9 \mathrm{E} 12$ & 0.400 & 5359 & $\mathrm{k}_{\mathrm{CH} 3 \mathrm{HCO}+\mathrm{H}}$ \\
\hline 71. & $\mathrm{CH}_{3} \mathrm{CHNH}+\mathrm{H}=\mathrm{CH}_{3} \mathrm{CHN}+\mathrm{H}_{2}$ & $2.4 \mathrm{E} 08$ & 1.500 & 7322 & $\mathrm{k}_{\mathrm{CH} 2 \mathrm{NH}+\mathrm{H}}$ \\
\hline 72. & $\mathrm{CH}_{3} \mathrm{CHNH}+\mathrm{O}=\mathrm{CH}_{3} \mathrm{CNH}+\mathrm{OH}$ & $1.8 \mathrm{E} 18$ & -1.900 & 2975 & $\mathrm{k}_{\mathrm{CH} 3 \mathrm{HCO}+\mathrm{O}}$ \\
\hline 73. & $\mathrm{CH}_{3} \mathrm{CHNH}+\mathrm{O}=\mathrm{CH}_{2} \mathrm{CHNH}+\mathrm{OH}$ & $3.7 \mathrm{E} 13$ & -0.200 & 3556 & $\mathrm{k}_{\mathrm{CH} 3 \mathrm{HCO}+\mathrm{O}}$ \\
\hline 74. & $\mathrm{CH}_{3} \mathrm{CHNH}+\mathrm{O}=\mathrm{CH}_{3} \mathrm{CHN}+\mathrm{OH}$ & $1.7 \mathrm{E} 08$ & 1.500 & 4630 & $\mathrm{k}_{\mathrm{CH} 2 \mathrm{NH}+\mathrm{O}}$ \\
\hline 75. & $\mathrm{CH}_{3} \mathrm{CHNH}+\mathrm{OH}=\mathrm{CH}_{3} \mathrm{CNH}+\mathrm{H}_{2} \mathrm{O}$ & $2.4 \mathrm{E} 11$ & 0.300 & -1000 & $\mathrm{k}_{\mathrm{CH} 3 \mathrm{HCO}+\mathrm{OH}}$ \\
\hline 76. & $\mathrm{CH}_{3} \mathrm{CHNH}+\mathrm{OH}=\mathrm{CH}_{2} \mathrm{CHNH}+\mathrm{H}_{2} \mathrm{O}$ & $3.0 \mathrm{E} 13$ & -0.600 & 800 & $\mathrm{k}_{\mathrm{CH} 3 \mathrm{HCO}+\mathrm{OH}}$ \\
\hline 77. & $\mathrm{CH}_{3} \mathrm{CHNH}+\mathrm{OH}=\mathrm{CH}_{3} \mathrm{CHN}+\mathrm{H}_{2} \mathrm{O}$ & $1.2 \mathrm{E} 06$ & 2.000 & -89 & $\mathrm{k}_{\mathrm{CH} 2 \mathrm{NH}+\mathrm{H}+\mathrm{OH}}$ \\
\hline 78. & $\mathrm{CH}_{3} \mathrm{CHNH}+\mathrm{CH}_{3}=\mathrm{CH}_{3} \mathrm{CNH}+\mathrm{CH}_{4}$ & $3.9 \mathrm{E}-7$ & 5.800 & 2200 & $\mathrm{k}_{\mathrm{CH} 3 \mathrm{HCO}+\mathrm{CH} 3}$ \\
\hline 79. & $\mathrm{CH}_{3} \mathrm{CHNH}+\mathrm{CH}_{3}=\mathrm{CH}_{2} \mathrm{CHNH}+\mathrm{CH}_{4}$ & $2.5 \mathrm{E} 01$ & 3.150 & 5727 & $\mathrm{k}_{\mathrm{CH} 3 \mathrm{HCO}+\mathrm{CH} 3}$ \\
\hline 80. & $\mathrm{CH}_{3} \mathrm{CHNH}+\mathrm{CH}_{3}=\mathrm{CH}_{3} \mathrm{CHN}+\mathrm{CH}_{4}$ & $8.2 \mathrm{E} 05$ & 1.870 & 7123 & $\mathrm{k}_{\mathrm{CH} 2 \mathrm{NH}+\mathrm{CH} 3}$ \\
\hline 81. & $\mathrm{CH}_{3} \mathrm{CHNH}+\mathrm{NH}_{2}=\mathrm{CH}_{3} \mathrm{CHN}+\mathrm{NH}_{3}$ & 9.2E05 & 1.940 & 4441 & $\mathrm{k}_{\mathrm{CH} 2 \mathrm{NH}+\mathrm{NH} 2}$ \\
\hline 82. & $\mathrm{C}_{2} \mathrm{H}_{2}+\mathrm{NH}_{2}=\mathrm{CHCHNH}_{2}$ & $7.8 \mathrm{E}-18$ & 8.310 & 7430 & {$[68]$} \\
\hline 83. & $\mathrm{CHCNH}_{2}+\mathrm{H}(+\mathrm{M})=\mathrm{CHCHNH}_{2}(+\mathrm{M})$ & $1.7 \mathrm{E} 10$ & 1.266 & 2709 & $\mathrm{k}_{\mathrm{C} 2 \mathrm{H} 2+\mathrm{H}(+\mathrm{M})}$ \\
\hline
\end{tabular}




\begin{tabular}{|c|c|c|c|c|c|}
\hline & Low pressure limit & 6.3E31 & -4.664 & 3780 & \\
\hline & TROE /0.7878 10212 1.E30/ & & & & \\
\hline 84. & $\mathrm{CHCHNH}_{2}+\mathrm{H}=\mathrm{CHCNH}_{2}+\mathrm{H}_{2}$ & $4.5 \mathrm{E} 13$ & 0.000 & 0 & $\mathrm{k}_{\mathrm{C} 2 \mathrm{H} 3+\mathrm{H}}$ \\
\hline 85. & $\mathrm{CHCHNH}_{2}+\mathrm{OH}=\mathrm{CHCNH}_{2}+\mathrm{H}_{2} \mathrm{O}$ & $2.0 \mathrm{E} 13$ & 0.000 & 0 & $\mathrm{k}_{\mathrm{C} 2 \mathrm{H} 3+\mathrm{OH}}$ \\
\hline 86. & $\mathrm{CHCHNH}_{2}+\mathrm{O}_{2}=\mathrm{OCHCHO}+\mathrm{NH}_{2}$ & $4.0 \mathrm{E} 12$ & 0.000 & 0 & $\mathrm{k}_{\mathrm{CHCHOH}+\mathrm{O} 2}$ \\
\hline 87. & $\mathrm{CHCHNH}_{2}+\mathrm{CH}_{3}=\mathrm{CHCNH}_{2}+\mathrm{CH}_{4}$ & $2.0 \mathrm{E} 13$ & 0.000 & 0 & $\mathrm{k}_{\mathrm{C} 2 \mathrm{H} 3+\mathrm{CH} 3}$ \\
\hline 88. & $\mathrm{CHCNH}_{2}+\mathrm{H}(+\mathrm{M})=\mathrm{CH}_{2} \mathrm{CNH}_{2}(+\mathrm{M})$ & $1.7 \mathrm{E} 10$ & 1.266 & 2709 & $\mathrm{k}_{\mathrm{C} 2 \mathrm{H} 2+\mathrm{H}(+\mathrm{M})}$ \\
\hline & Low pressure limit & 6.3E31 & -4.664 & 3780 & \\
\hline & TROE /0.7878 10212 1.E30/ & & & & \\
\hline 89. & $\mathrm{CH}_{2} \mathrm{CNH}_{2}+\mathrm{H}=\mathrm{CHCNH}_{2}+\mathrm{H}_{2}$ & $4.5 \mathrm{E} 13$ & 0.000 & 0 & $\mathrm{k}_{\mathrm{C} 2 \mathrm{H} 3+\mathrm{H}}$ \\
\hline 90. & $\mathrm{CH}_{2} \mathrm{CNH}_{2}+\mathrm{O}=\mathrm{CH}_{2} \mathrm{CO}+\mathrm{NH}_{2}$ & $3.0 \mathrm{E} 13$ & 0.000 & 0 & $\mathrm{k}_{\mathrm{C} 2 \mathrm{H} 3+\mathrm{O}}$ \\
\hline 91. & $\mathrm{CH}_{2} \mathrm{CNH}_{2}+\mathrm{OH}=\mathrm{CHCNH}_{2}+\mathrm{H}_{2} \mathrm{O}$ & $2.0 \mathrm{E} 13$ & 0.000 & 0 & $\mathrm{k}_{\mathrm{C} 2 \mathrm{H} 3+\mathrm{OH}}$ \\
\hline 92. & $\mathrm{CH}_{2} \mathrm{CNH}_{2}+\mathrm{O}_{2}=\mathrm{OCHCHO}+\mathrm{NH}_{2}$ & $4.0 \mathrm{E} 12$ & 0.000 & 0 & $\mathrm{k}_{\mathrm{C} 2 \mathrm{H} 3+\mathrm{O} 2}$ \\
\hline 93. & $\mathrm{CH}_{2} \mathrm{CNH}_{2}+\mathrm{CH}_{3}=\mathrm{CHCNH}_{2}+\mathrm{CH}_{4}$ & $2.0 \mathrm{E} 13$ & 0.000 & 0 & $\mathrm{k}_{\mathrm{C} 2 \mathrm{H} 3+\mathrm{CH} 3}$ \\
\hline 94. & $\mathrm{CH}_{2} \mathrm{CHNH}+\mathrm{H}=\mathrm{CH}_{3}+\mathrm{HCNH}$ & $1.0 \mathrm{E} 14$ & 0.000 & 0 & $\mathrm{k}_{\mathrm{CH} 2 \mathrm{CHO}+\mathrm{H}}$ \\
\hline 95. & $\mathrm{CH}_{2} \mathrm{CHNH}+\mathrm{H}=\mathrm{CH}_{3} \mathrm{CNH}+\mathrm{H}$ & $3.0 \mathrm{E} 13$ & 0.000 & 0 & $\mathrm{k}_{\mathrm{CH} 2 \mathrm{CHO}+\mathrm{H}}$ \\
\hline 96. & $\mathrm{CH}_{2} \mathrm{CHNH}+\mathrm{H}=\mathrm{CH}_{2} \mathrm{CNH}+\mathrm{H}_{2}$ & $2.0 \mathrm{E} 13$ & 0.000 & 0 & $\mathrm{k}_{\mathrm{CH} 2 \mathrm{CHO}+\mathrm{H}}$ \\
\hline 97. & $\mathrm{CH}_{2} \mathrm{CHNH}+\mathrm{O}=\mathrm{CH}_{2} \mathrm{CNH}+\mathrm{OH}$ & $2.0 \mathrm{E} 13$ & 0.000 & 0 & $\mathrm{k}_{\mathrm{CH} 2 \mathrm{CHO}+\mathrm{O}}$ \\
\hline 98. & $\mathrm{CH}_{2} \mathrm{CHNH}+\mathrm{OH}=\mathrm{CH}_{2} \mathrm{CNH}+\mathrm{H}_{2} \mathrm{O}$ & $2.0 \mathrm{E} 13$ & 0.000 & 0 & $\mathrm{k}_{\mathrm{CH} 2 \mathrm{CHO}+\mathrm{OH}}$ \\
\hline 99. & $\mathrm{CH}_{2} \mathrm{CHNH}+\mathrm{OH}=\mathrm{CH}_{2} \mathrm{OH}+\mathrm{HCNH}$ & $1.0 \mathrm{E} 13$ & 0.000 & 0 & $\mathrm{k}_{\mathrm{CH} 2 \mathrm{CHO}+\mathrm{OH}}$ \\
\hline 100. & $\mathrm{CH}_{2} \mathrm{CHNH}+\mathrm{O}_{2}=\mathrm{CH}_{2} \mathrm{O}+\mathrm{CO}+\mathrm{NH}_{2}$ & $5.7 \mathrm{E} 17$ & -1.757 & 11067 & $\mathrm{k}_{\mathrm{CH} 2 \mathrm{CHO}+\mathrm{O} 2}$ \\
\hline 101. & $\mathrm{CH}_{3} \mathrm{CNH}=\mathrm{CH}_{3}+\mathrm{HNC}$ & $6.5 \mathrm{E} 18$ & -2.520 & 33000 & $\mathrm{k}_{\mathrm{CH} 3 \mathrm{CO}}, \mathrm{E}_{\mathrm{a}}$ adj. \\
\hline 102. & $\mathrm{CH}_{3} \mathrm{CNH}=\mathrm{CH}_{3} \mathrm{CN}+\mathrm{H}$ & 7.7E25 & -5.200 & 24000 & $\mathrm{k}_{\mathrm{CH} 3 \mathrm{CO}}, \mathrm{E}_{\mathrm{a}}$ adj. \\
\hline 103. & $\mathrm{CH}_{3} \mathrm{CNH}+\mathrm{H}=\mathrm{CH}_{3}+\mathrm{HCNH}$ & $2.1 \mathrm{E} 13$ & 0.000 & 0 & $\mathrm{k}_{\mathrm{CH} 3 \mathrm{CO}+\mathrm{H}}$ \\
\hline 104. & $\mathrm{CH}_{3} \mathrm{CNH}+\mathrm{H}=\mathrm{CH}_{2} \mathrm{CNH}+\mathrm{H}_{2}$ & $1.2 \mathrm{E} 13$ & 0.000 & 0 & $\mathrm{k}_{\mathrm{CH} 3 \mathrm{CO}+\mathrm{H}}$ \\
\hline 105. & $\mathrm{CH}_{3} \mathrm{CNH}+\mathrm{H}=\mathrm{CH}_{3} \mathrm{CN}+\mathrm{H}_{2}$ & $2.4 \mathrm{E} 08$ & 1.500 & -894 & $\mathrm{k}_{\mathrm{HCNH}+\mathrm{H}}$ \\
\hline 106. & $\mathrm{CH}_{3} \mathrm{CNH}+\mathrm{O}=\mathrm{CH}_{3}+\mathrm{HNCO}$ & $1.6 \mathrm{E} 14$ & 0.000 & 0 & $\mathrm{k}_{\mathrm{CH} 3 \mathrm{CO}+\mathrm{O}}$ \\
\hline 107. & $\mathrm{CH}_{3} \mathrm{CNH}+\mathrm{O}=\mathrm{CH}_{2} \mathrm{CNH}+\mathrm{OH}$ & 5.3E13 & 0.000 & 0 & $\mathrm{k}_{\mathrm{CH} 3 \mathrm{CO}+\mathrm{O}}$ \\
\hline 108. & $\mathrm{CH}_{3} \mathrm{CNH}+\mathrm{O}=\mathrm{CH}_{3} \mathrm{CN}+\mathrm{OH}$ & $1.7 \mathrm{E} 08$ & 1.500 & -894 & $\mathrm{k}_{\mathrm{HCNH}+\mathrm{O}}$ \\
\hline 109. & $\mathrm{CH}_{3} \mathrm{CNH}+\mathrm{OH}=\mathrm{CH}_{2} \mathrm{CNH}+\mathrm{H}_{2} \mathrm{O}$ & $1.2 \mathrm{E} 13$ & 0.000 & 0 & $\mathrm{k}_{\mathrm{CH} 3 \mathrm{CO}+\mathrm{OH}}$ \\
\hline 110. & $\mathrm{CH}_{3} \mathrm{CNH}+\mathrm{OH}=\mathrm{CH}_{3} \mathrm{CN}+\mathrm{H}_{2} \mathrm{O}$ & $1.2 \mathrm{E} 06$ & 2.000 & -1192 & $\mathrm{k}_{\mathrm{HCNH}+\mathrm{OH}}$ \\
\hline 111. & $\mathrm{CH}_{3} \mathrm{CNH}+\mathrm{O}_{2}=\mathrm{CH}_{2} \mathrm{O}+\mathrm{CO}+\mathrm{NH}_{2}$ & 1.9E12 & 0.000 & 0 & $\mathrm{k}_{\mathrm{CH} 3 \mathrm{CO}+\mathrm{O} 2}$ \\
\hline 112. & $\mathrm{CH}_{3} \mathrm{CNH}+\mathrm{CH}_{3}=\mathrm{CH}_{2} \mathrm{CNH}+\mathrm{CH}_{4}$ & $5.3 \mathrm{E} 13$ & 0.000 & 0 & $\mathrm{k}_{\mathrm{CH} 3 \mathrm{CO}+\mathrm{CH} 4}$ \\
\hline 113. & $\mathrm{CH}_{3} \mathrm{CNH}+\mathrm{CH}_{3}=\mathrm{CH}_{3} \mathrm{CN}+\mathrm{CH}_{4}$ & $8.2 \mathrm{E} 05$ & 1.870 & -1113 & $\mathrm{k}_{\mathrm{HCNH}+\mathrm{CH} 4}$ \\
\hline 114. & $\mathrm{CH}_{3}+\mathrm{HCN}=\mathrm{CH}_{3} \mathrm{CHN}$ & $1.0 \mathrm{E} 12$ & 0.000 & 9900 & [69], est. \\
\hline 115. & $\mathrm{CH}_{3} \mathrm{CHN}+\mathrm{H}=\mathrm{CH}_{3} \mathrm{CN}+\mathrm{H}_{2}$ & 2.4E08 & 1.500 & -894 & $\mathrm{k}_{\mathrm{H} 2 \mathrm{CN}+\mathrm{H}}$ \\
\hline 116. & $\mathrm{CH}_{3} \mathrm{CHN}+\mathrm{H}=\mathrm{CH}_{2} \mathrm{CHN}+\mathrm{H}_{2}$ & $9.0 \mathrm{E} 13$ & 0.000 & 15100 & $\mathrm{k}_{\mathrm{CH} 3+\mathrm{H}}$ \\
\hline 117. & $\mathrm{CH}_{2} \mathrm{CHN}(\mathrm{s})+\mathrm{H}_{2}=\mathrm{CH}_{3} \mathrm{CHN}+\mathrm{H}$ & $7.2 \mathrm{E} 13$ & 0.000 & 0 & $\mathrm{k}_{\mathrm{CH} 2(\mathrm{~s})+\mathrm{H} 2}$ \\
\hline 118. & $\mathrm{CH}_{3} \mathrm{CHN}+\mathrm{O}=\mathrm{CH}_{3} \mathrm{CN}+\mathrm{OH}$ & $1.7 \mathrm{E} 08$ & 1.500 & -894 & $\mathrm{k}_{\mathrm{H} 2 \mathrm{CN}+\mathrm{O}}$ \\
\hline 119. & $\mathrm{CH}_{3} \mathrm{CHN}+\mathrm{OH}=\mathrm{CH}_{3} \mathrm{CN}+\mathrm{H}_{2} \mathrm{O}$ & $1.2 \mathrm{E} 06$ & 2.000 & -1192 & $\mathrm{k}_{\mathrm{H} 2 \mathrm{CN}+\mathrm{OH}}$ \\
\hline 120. & $\mathrm{CH}_{3} \mathrm{CHN}+\mathrm{OH}=\mathrm{CH}_{2} \mathrm{CHN}+\mathrm{H}_{2} \mathrm{O}$ & $1.1 \mathrm{E} 03$ & 3.000 & 2780 & $\mathrm{k}_{\mathrm{CH} 3+\mathrm{OH}}$ \\
\hline 121. & $\mathrm{CH}_{3} \mathrm{CHN}+\mathrm{OH}=\mathrm{CH}_{2} \mathrm{CHN}(\mathrm{s})+\mathrm{H}_{2} \mathrm{O}$ & $4.4 \mathrm{E} 13$ & -0.3485 & -727 & $\mathrm{k}_{\mathrm{CH} 3+\mathrm{OH}}$ \\
\hline 122. & $\mathrm{CH}_{3} \mathrm{CHN}+\mathrm{NH}_{2}=\mathrm{CH}_{3} \mathrm{CN}+\mathrm{NH}_{3}$ & $9.2 \mathrm{E} 05$ & 1.940 & -1152 & $\mathrm{k}_{\mathrm{H} 2 \mathrm{CN}+\mathrm{NH} 2}$ \\
\hline 123. & $\mathrm{CHCNH}_{2}+\mathrm{H}=\mathrm{CHCNH}+\mathrm{H}_{2}$ & $4.8 \mathrm{E} 08$ & 1.500 & 9706 & $\mathrm{k}_{\mathrm{CH} 3 \mathrm{NH} 2+\mathrm{H}}$ \\
\hline 124. & $\mathrm{CHCNH}_{2}+\mathrm{O}=\mathrm{CHCNH}+\mathrm{OH}$ & 3.3E08 & 1.500 & 6348 & $\mathrm{k}_{\mathrm{CH} 3 \mathrm{NH} 2+\mathrm{O}}$ \\
\hline 125. & $\mathrm{CHCNH}_{2}+\mathrm{O}=\mathrm{HCCO}+\mathrm{NH}_{2}$ & $1.4 \mathrm{E} 07$ & 2.000 & 1900 & $\mathrm{k}_{\mathrm{C} 2 \mathrm{H} 2+\mathrm{O}}$ \\
\hline 126. & $\mathrm{CHCNH}_{2}+\mathrm{OH}=\mathrm{CHCNH}+\mathrm{H}_{2} \mathrm{O}$ & $2.0 \mathrm{E} 12$ & 0.000 & 0 & $\mathrm{k}_{\mathrm{CH} 3 \mathrm{NH} 2+\mathrm{OH}}$ \\
\hline 127. & $\mathrm{CHCNH}_{2}+\mathrm{CH}_{3}=\mathrm{CHCNH}+\mathrm{CH}_{4}$ & $1.6 \mathrm{E} 06$ & 1.870 & 8842 & $\mathrm{k}_{\mathrm{CH} 3 \mathrm{NH} 2+\mathrm{CH} 3}$ \\
\hline 128. & $\mathrm{CHCNH}_{2}+\mathrm{NH}_{2}=\mathrm{CHCNH}+\mathrm{NH}_{3}$ & $1.8 \mathrm{E} 06$ & 1.940 & 7143 & $\mathrm{k}_{\mathrm{CH} 3 \mathrm{NH} 2+\mathrm{NH} 2}$ \\
\hline
\end{tabular}




\begin{tabular}{|c|c|c|c|c|c|}
\hline 129. & $\mathrm{CH}_{2} \mathrm{CNH}=\mathrm{CH}_{3} \mathrm{CN}$ & $2.5 \mathrm{E} 13$ & 0.000 & 70300 & [53] \\
\hline 130. & $\mathrm{CH}_{2} \mathrm{CNH}+\mathrm{H}=\mathrm{CH}_{3} \mathrm{CN}+\mathrm{H}$ & $3.0 \mathrm{E} 13$ & 0.000 & 0 & est. \\
\hline 131. & $\mathrm{CH}_{2} \mathrm{CNH}+\mathrm{H}=\mathrm{CH}_{3}+\mathrm{HNC}$ & $3.3 \mathrm{E} 10$ & 0.851 & 2840 & $\mathrm{k}_{\mathrm{CH} 2 \mathrm{CO}+\mathrm{H}}$ \\
\hline 132. & $\mathrm{CH}_{2} \mathrm{CNH}+\mathrm{H}=\mathrm{CHCNH}+\mathrm{H}_{2}$ & $3.0 \mathrm{E} 07$ & 2.000 & 10000 & $\mathrm{k}_{\mathrm{CH} 2 \mathrm{CO}+\mathrm{H}}$ \\
\hline 133. & $\mathrm{CH}_{2} \mathrm{CNH}+\mathrm{H}=\mathrm{CH}_{2} \mathrm{CN}+\mathrm{H}_{2}$ & $2.4 \mathrm{E} 08$ & 1.500 & 7322 & $\mathrm{k}_{\mathrm{CH} 2 \mathrm{NH}+\mathrm{H}}$ \\
\hline 134. & $\mathrm{CH}_{2} \mathrm{CNH}+\mathrm{O}=\mathrm{CH}_{2}+\mathrm{HNCO}$ & $1.8 \mathrm{E} 12$ & 0.000 & 1350 & $\mathrm{k}_{\mathrm{CH} 2 \mathrm{CO}+\mathrm{O}}$ \\
\hline 135. & $\mathrm{CH}_{2} \mathrm{CNH}+\mathrm{O}=\mathrm{CHCNH}+\mathrm{OH}$ & $2.0 \mathrm{E} 07$ & 2.000 & 10000 & $\mathrm{k}_{\mathrm{CH} 2 \mathrm{CO}+\mathrm{O}}$ \\
\hline 136. & $\mathrm{CH}_{2} \mathrm{CNH}+\mathrm{O}=\mathrm{CH}_{2} \mathrm{CN}+\mathrm{OH}$ & $1.7 \mathrm{E} 08$ & 1.500 & 4630 & $\mathrm{k}_{\mathrm{CH} 2 \mathrm{NH}+\mathrm{H}}$ \\
\hline 137. & $\mathrm{CH}_{2} \mathrm{CNH}+\mathrm{OH}=\mathrm{CH}_{2} \mathrm{OH}+\mathrm{HNC}$ & $1.0 \mathrm{E} 12$ & 0.000 & -1013 & $\mathrm{k}_{\mathrm{CH} 2 \mathrm{CO}+\mathrm{OH}}$ \\
\hline 138. & $\mathrm{CH}_{2} \mathrm{CNH}+\mathrm{OH}=\mathrm{CH}_{3}+\mathrm{HNCO}$ & $6.7 \mathrm{E} 11$ & 0.000 & -1013 & $\mathrm{k}_{\mathrm{CH} 2 \mathrm{CO}+\mathrm{OH}}$ \\
\hline 139. & $\mathrm{CH}_{2} \mathrm{CNH}+\mathrm{OH}=\mathrm{CHCNH}+\mathrm{H}_{2} \mathrm{O}$ & $1.0 \mathrm{E} 07$ & 2.000 & 3000 & $\mathrm{k}_{\mathrm{CH} 2 \mathrm{CO}+\mathrm{OH}}$ \\
\hline 140. & $\mathrm{CH}_{2} \mathrm{CNH}+\mathrm{OH}=\mathrm{CH}_{2} \mathrm{CN}+\mathrm{H}_{2} \mathrm{O}$ & $1.2 \mathrm{E} 06$ & 2.000 & -89 & $\mathrm{k}_{\mathrm{CH} 2 \mathrm{NH}+\mathrm{OH}}$ \\
\hline 141. & $\mathrm{CH}_{2} \mathrm{CNH}+\mathrm{CH}_{3}=\mathrm{CH}_{2} \mathrm{CN}+\mathrm{CH}_{4}$ & $8.2 \mathrm{E} 05$ & 1.870 & 7123 & $\mathrm{k}_{\mathrm{CH} 2 \mathrm{NH}+\mathrm{CH} 3}$ \\
\hline 142. & $\mathrm{CH}_{2} \mathrm{CNH}+\mathrm{NH}_{2}=\mathrm{CH}_{2} \mathrm{CN}+\mathrm{NH}_{3}$ & 9.2E05 & 1.940 & 4441 & $\mathrm{k}_{\mathrm{CH} 2 \mathrm{NH}+\mathrm{NH} 2}$ \\
\hline 143. & $\mathrm{CH}_{2} \mathrm{CHN}+\mathrm{H}=\mathrm{CH}_{3}+\mathrm{HCN}$ & $1.0 \mathrm{E} 13$ & 0.000 & 0 & est. \\
\hline 144. & $\mathrm{CH}_{2} \mathrm{CHN}+\mathrm{O}=\mathrm{CH}_{2} \mathrm{O}+\mathrm{HCN}$ & $5.0 \mathrm{E} 13$ & 0.000 & 0 & est. \\
\hline 145. & $\mathrm{CH}_{2} \mathrm{CHN}+\mathrm{O}_{2}=\mathrm{CH}_{2} \mathrm{O}+\mathrm{HNCO}$ & $1.0 \mathrm{E} 12$ & 0.000 & 0 & est. \\
\hline 146. & $\mathrm{CH}_{2} \mathrm{CHN}(\mathrm{s})+\mathrm{M}=\mathrm{CH}_{2} \mathrm{CHN}+\mathrm{M}$ & $1.0 \mathrm{E} 13$ & 0.000 & 0 & est. \\
\hline 147. & $\mathrm{CH}_{2} \mathrm{CHN}(\mathrm{s})=\mathrm{c}-\mathrm{C}_{2} \mathrm{H}_{3} \mathrm{~N}$ & $3.0 \mathrm{E} 13$ & 0.000 & 4000 & est., see text \\
\hline 148. & $\mathrm{CH}_{2} \mathrm{CHN}(\mathrm{s})=\mathrm{CH}_{3} \mathrm{CN}$ & $3.0 \mathrm{E} 13$ & 0.000 & 8000 & est. \\
\hline 149. & $\mathrm{CH}_{2} \mathrm{CHN}(\mathrm{s})+\mathrm{H}=\mathrm{CH}_{2} \mathrm{CHN}+\mathrm{H}$ & $1.0 \mathrm{E} 14$ & 0.000 & 0 & est. \\
\hline 150. & $\mathrm{CH}_{2} \mathrm{CHN}(\mathrm{s})+\mathrm{O}=>\mathrm{HCO}+\mathrm{HCN}+\mathrm{H}$ & $3.0 \mathrm{E} 13$ & 0.000 & 0 & est. \\
\hline 151. & $\mathrm{CH}_{2} \mathrm{CHN}(\mathrm{s})+\mathrm{OH}=>\mathrm{CH}_{2} \mathrm{O}+\mathrm{HCN}+\mathrm{H}$ & $3.0 \mathrm{E} 13$ & 0.000 & 0 & est. \\
\hline 152. & $\mathrm{c}-\mathrm{C}_{2} \mathrm{H}_{3} \mathrm{~N}=\mathrm{CH}_{3} \mathrm{CN}$ & 4.7E13 & 0.000 & 41500 & $\mathrm{Pw}$ \\
\hline 153. & $\mathrm{c}-\mathrm{C}_{2} \mathrm{H}_{3} \mathrm{~N}+\mathrm{H}=\mathrm{CH}_{2} \mathrm{NCH}_{2}$ & $9.8 \mathrm{E} 09$ & 1.212 & 1969 & $\mathrm{Pw}$ \\
\hline 154. & $\mathrm{c}-\mathrm{C}_{2} \mathrm{H}_{3} \mathrm{~N}+\mathrm{H}=\mathrm{CH}_{2} \mathrm{CHNH}$ & $1.1 \mathrm{E} 10$ & 1.229 & 2422 & $\mathrm{Pw}$ \\
\hline 155. & $\mathrm{c}-\mathrm{C}_{2} \mathrm{H}_{3} \mathrm{~N}+\mathrm{O}=>\mathrm{H}_{2} \mathrm{CN}+\mathrm{HCO}$ & $1.0 \mathrm{E} 13$ & 0.000 & 0 & est. \\
\hline 156. & $\mathrm{c}-\mathrm{C}_{2} \mathrm{H}_{3} \mathrm{~N}+\mathrm{O}=>\mathrm{C}_{2} \mathrm{H}_{3}+\mathrm{NO}$ & $1.0 \mathrm{E} 13$ & 0.000 & 0 & est. \\
\hline 157. & $\mathrm{c}-\mathrm{C}_{2} \mathrm{H}_{3} \mathrm{~N}+\mathrm{OH}=>\mathrm{H}_{2} \mathrm{CN}+\mathrm{CH}_{2} \mathrm{O}$ & $5.0 \mathrm{E} 12$ & 0.000 & 0 & est. \\
\hline 158. & $\mathrm{CH}_{3} \mathrm{CN}=\mathrm{CH}_{2} \mathrm{CN}+\mathrm{H}$ & $7.9 \mathrm{E} 14$ & 0.000 & 94940 & {$[70]$} \\
\hline 159. & $\mathrm{CH}_{3} \mathrm{CN}+\mathrm{H}=\mathrm{HCN}+\mathrm{CH}_{3}$ & $4.4 \mathrm{E} 10$ & 0.800 & 6800 & [69], $0.001 \mathrm{bar}$ \\
\hline 160. & $\mathrm{CH}_{3} \mathrm{CN}+\mathrm{H}=\mathrm{HNC}+\mathrm{CH}_{3}$ & $2.8 \mathrm{E} 15$ & -0.320 & 20030 & [69], $0.001 \mathrm{bar}$ \\
\hline 161. & $\mathrm{CH}_{3} \mathrm{CN}+\mathrm{H}=\mathrm{CH}_{2} \mathrm{CN}+\mathrm{H}_{2}$ & $6.0 \mathrm{E} 04$ & 3.010 & 8522 & [69] \\
\hline 162. & $\mathrm{CH}_{3} \mathrm{CN}+\mathrm{O}=\mathrm{CH}_{3}+\mathrm{NCO}$ & $6.0 \mathrm{E} 09$ & 1.800 & 8130 & {$[71]$} \\
\hline 163. & $\mathrm{CH}_{3} \mathrm{CN}+\mathrm{O}=\mathrm{CH}_{2} \mathrm{CN}+\mathrm{OH}$ & 4.7E08 & 1.180 & 14360 & [71] \\
\hline 164. & $\mathrm{CH}_{3} \mathrm{CN}+\mathrm{OH}=\mathrm{CH}_{2} \mathrm{CN}+\mathrm{H}_{2} \mathrm{O}$ & $2.0 \mathrm{E} 07$ & 2.000 & 2000 & {$[55]$} \\
\hline 165. & $\mathrm{CH}_{3} \mathrm{CN}+\mathrm{CH}_{3}=\mathrm{CH}_{2} \mathrm{CN}+\mathrm{CH}_{4}$ & $5.0 \mathrm{E} 12$ & 0.000 & 7000 & {$[70]$} \\
\hline 166. & $\mathrm{CH}_{3} \mathrm{CN}+\mathrm{CN}=\mathrm{CH}_{2} \mathrm{CN}+\mathrm{HCN}$ & $5.0 \mathrm{E} 13$ & 0.000 & 2000 & {$[70]$} \\
\hline 167. & $\mathrm{CH}_{2} \mathrm{CN}+\mathrm{O}=\mathrm{CH}_{2} \mathrm{O}+\mathrm{CN}$ & $1.3 \mathrm{E} 12$ & 0.640 & 0 & {$[72]$} \\
\hline 168. & $\mathrm{CH}_{2} \mathrm{OH}+\mathrm{CN}=\mathrm{CH}_{2} \mathrm{CN}+\mathrm{OH}$ & $5.0 \mathrm{E} 13$ & 0.000 & 0 & {$[55]$} \\
\hline 169. & $\mathrm{CHCNH}+\mathrm{H}=\mathrm{CH}_{2}+\mathrm{HNC}$ & $1.5 \mathrm{E} 14$ & 0.000 & 0 & $\mathrm{k}_{\mathrm{HCCO}+\mathrm{H}}$ \\
\hline 170. & $\mathrm{CHCNH}+\mathrm{O}=\mathrm{CO}+\mathrm{HNC}$ & $1.0 \mathrm{E} 14$ & 0.000 & 0 & $\mathrm{k}_{\mathrm{HCCO}+\mathrm{O}}$ \\
\hline 171. & $\mathrm{CHCNH}+\mathrm{OH}=\mathrm{HCO}+\mathrm{HCNH}$ & $1.0 \mathrm{E} 13$ & 0.000 & 0 & $\mathrm{k}_{\mathrm{HCCO}+\mathrm{OH}}$ \\
\hline 172. & $\mathrm{CHCNH}+\mathrm{O}_{2}=\mathrm{HNCO}+\mathrm{HCO}$ & $4.9 \mathrm{E} 12$ & -0.142 & 1150 & $\mathrm{k}_{\mathrm{HCCO}+\mathrm{O} 2}$ \\
\hline 173. & $\mathrm{CHCNH}+\mathrm{O}_{2}=\mathrm{HNC}+\mathrm{CO}+\mathrm{OH}$ & $1.6 \mathrm{E} 11$ & -0.020 & 1020 & $\mathrm{k}_{\mathrm{HCCO}+\mathrm{O} 2}$ \\
\hline 174. & $\mathrm{CHCNH}+\mathrm{O}_{2}=\mathrm{HNC}+\mathrm{HCO}+\mathrm{O}$ & $2.2 \mathrm{E} 02$ & 2.690 & 3540 & $\mathrm{k}_{\mathrm{HCCO}+\mathrm{O} 2}$ \\
\hline \multirow[t]{2}{*}{175.} & $\mathrm{H}_{2} \mathrm{NCHO}(+\mathrm{M})=\mathrm{CO}+\mathrm{NH}_{3}(+\mathrm{M})$ & $1.0 \mathrm{E} 14$ & 0.000 & 75514 & [73] \\
\hline & Low pressure limit & $8.3 \mathrm{E} 14$ & 0.000 & 49084 & \\
\hline 176. & $\mathrm{H}_{2} \mathrm{NCHO}+\mathrm{M}=\mathrm{HCO}+\mathrm{NH}_{2}+\mathrm{M}$ & $1.4 \mathrm{E} 16$ & 0.000 & 72900 & {$[73]$} \\
\hline
\end{tabular}




\begin{tabular}{|l|l|c|c|c|l|}
\hline 177. & $\mathrm{H}_{2} \mathrm{NCHO}+\mathrm{M}=\mathrm{H}_{2} \mathrm{NCO}+\mathrm{H}+\mathrm{M}$ & $4.6 \mathrm{E} 15$ & 0.000 & 64200 & {$[73]$} \\
\hline 178. & $\mathrm{H}_{2} \mathrm{NCHO}+\mathrm{H}=\mathrm{H}_{2} \mathrm{NCO}+\mathrm{H}_{2}$ & $1.3 \mathrm{E} 13$ & 0.000 & 6955 & {$[74]$} \\
\hline 179. & $\mathrm{H}_{2} \mathrm{NCHO}+\mathrm{H}=\mathrm{HCO}+\mathrm{NH}_{3}$ & $1.0 \mathrm{E} 13$ & 0.000 & 19100 & {$[74]$, est. } \\
\hline 180. & $\mathrm{H}_{2} \mathrm{NCHO}+\mathrm{O}=\mathrm{H}_{2} \mathrm{NCO}+\mathrm{OH}$ & $4.0 \mathrm{E} 08$ & 1.500 & 5196 & $\mathrm{k}_{\mathrm{CH} 3 \mathrm{NH} 2+\mathrm{O}}$ \\
\hline 181. & $\mathrm{H}_{2} \mathrm{NCHO}+\mathrm{OH}=\mathrm{H}_{2} \mathrm{NCO}+\mathrm{H}_{2} \mathrm{O}$ & $8.0 \mathrm{E} 12$ & 0.000 & 0 & $\mathrm{k}_{\mathrm{CH} 3 \mathrm{NH} 2+\mathrm{OH}}$ \\
\hline 182. & $\mathrm{H}_{2} \mathrm{NCHO}+\mathrm{CH}_{3}=\mathrm{H}_{2} \mathrm{NCO}+\mathrm{CH}_{4}$ & $7.0 \mathrm{E} 05$ & 2.000 & 9000 & {$[75]$, est. } \\
\hline 183. & $\mathrm{H}_{2} \mathrm{NCHO}+\mathrm{NH}_{2}=\mathrm{H}_{2} \mathrm{NCO}_{2}+\mathrm{NH}_{3}$ & $2.0 \mathrm{E} 06$ & 2.000 & 5000 & {$[76]$, est. } \\
\hline 184. & $\left.\mathrm{H}_{2} \mathrm{NCO}+\mathrm{M}\right)=\mathrm{CO}+\mathrm{NH}_{2}(+\mathrm{M})$ & $5.9 \mathrm{E} 12$ & 0.000 & 25000 & {$[76]$} \\
\hline & Low pressure limit & $1.0 \mathrm{E} 14$ & 0.000 & 21700 & \\
\hline 185. & $\mathrm{H}_{2} \mathrm{NCO}+\mathrm{H}=\mathrm{HNCO}+\mathrm{H}_{2}$ & $3.0 \mathrm{E} 13$ & 0.000 & 0 & est. \\
\hline 186. & $\mathrm{H}_{2} \mathrm{NCO}+\mathrm{O}=\mathrm{HNCO}+\mathrm{OH}$ & $3.0 \mathrm{E} 13$ & 0.000 & 0 & est. \\
\hline 187. & $\mathrm{H}_{2} \mathrm{NCO}+\mathrm{OH}=\mathrm{HNCO}+\mathrm{H}_{2} \mathrm{O}$ & 0.000 & 0 & est. \\
\hline
\end{tabular}

a: 0.04 bar, $700-2500 \mathrm{~K}$

pw: present work; adj.: adjusted 
App. B. $\mathrm{CH}_{3} \mathrm{NHCH}_{3}$ subset of the reaction mechanism. Rate constants are listed in the form

$A T^{\mathrm{n}} \exp \left(-\mathrm{E}_{\mathrm{a}} / \mathrm{RT}\right)$. Units are calories, $\mathrm{cm}^{3}$, mol, second.

\begin{tabular}{|c|c|c|c|c|c|}
\hline \multicolumn{2}{|r|}{ Reaction Mechanism } & \multirow{2}{*}{$\begin{array}{c}\mathrm{A} \\
5.2 \mathrm{E} 17\end{array}$} & \multirow{2}{*}{$\begin{array}{c}\mathrm{N} \\
-0.990\end{array}$} & \multirow{2}{*}{$\begin{array}{c}E_{a} \\
1580\end{array}$} & \multirow{2}{*}{$\begin{array}{l}\text { Source } \\
k_{\mathrm{C} 2 \mathrm{H} 5+\mathrm{H}(+\mathrm{M})}\end{array}$} \\
\hline 188. & $\mathrm{CH}_{3} \mathrm{NHCH}_{2}+\mathrm{H}(+\mathrm{M})=\mathrm{CH}_{3} \mathrm{NHCH}_{3}(+\mathrm{M})$ & & & & \\
\hline & Low pressure limit & $2.0 \mathrm{E} 41$ & -7.080 & 6685 & \\
\hline & TROE /0.8422 $12522196882 /$ & & & & \\
\hline 189. & $\mathrm{CH}_{3} \mathrm{NCH}_{3}+\mathrm{H}=\mathrm{CH}_{3} \mathrm{NHCH}_{3}$ & $1.0 \mathrm{E} 12$ & 0.000 & 0 & est. \\
\hline 190. & $\mathrm{CH}_{3} \mathrm{NHCH}_{3}+\mathrm{H}=\mathrm{CH}_{3} \mathrm{NHCH}_{2}+\mathrm{H}_{2}$ & $5.6 \mathrm{E} 08$ & 1.500 & 5464 & $\mathrm{k}_{\mathrm{CH} 3 \mathrm{NH} 2+\mathrm{H}}$ \\
\hline 191. & $\mathrm{CH}_{3} \mathrm{NHCH}_{3}+\mathrm{H}=\mathrm{CH}_{3} \mathrm{NCH}_{3}+\mathrm{H}_{2}$ & $4.8 \mathrm{E} 08$ & 1.500 & 9706 & $\mathrm{k}_{\mathrm{CH} 3 \mathrm{NH} 2+\mathrm{H}}$ \\
\hline 192. & $\mathrm{CH}_{3} \mathrm{NHCH}_{3}+\mathrm{O}=\mathrm{CH}_{3} \mathrm{NHCH}_{2}+\mathrm{OH}$ & $6.1 \mathrm{E} 12$ & 0.000 & 556 & [29], est. \\
\hline 193. & $\mathrm{CH}_{3} \mathrm{NHCH}_{3}+\mathrm{O}=\mathrm{CH}_{3} \mathrm{NCH}_{3}+\mathrm{OH}$ & $3.0 \mathrm{E} 12$ & 0.000 & 556 & [29], est. \\
\hline 194. & $\mathrm{CH}_{3} \mathrm{NHCH}_{3}+\mathrm{OH}=\mathrm{CH}_{3} \mathrm{NHCH}_{2}+\mathrm{H}_{2} \mathrm{O}$ & $2.0 \mathrm{E} 13$ & 0.000 & 0 & {$[62,63]$} \\
\hline 195. & $\mathrm{CH}_{3} \mathrm{NHCH}_{3}+\mathrm{OH}=\mathrm{CH}_{3} \mathrm{NCH}_{3}+\mathrm{H}_{2} \mathrm{O}$ & $1.9 \mathrm{E} 13$ & 0.000 & 0 & {$[62,63]$} \\
\hline 196. & $\mathrm{CH}_{3} \mathrm{NHCH}_{3}+\mathrm{CH}_{3}=\mathrm{CH}_{3} \mathrm{NHCH}_{2}+\mathrm{CH}_{4}$ & $1.5 \mathrm{E} 06$ & 1.870 & 9170 & $\mathrm{k}_{\mathrm{CH} 3 \mathrm{NH} 2+\mathrm{CH} 3}$ \\
\hline 197. & $\mathrm{CH}_{3} \mathrm{NHCH}_{3}+\mathrm{CH}_{3}=\mathrm{CH}_{3} \mathrm{NCH}_{3}+\mathrm{CH}_{4}$ & $1.6 \mathrm{E} 06$ & 1.870 & 8842 & $\mathrm{k}_{\mathrm{CH} 3 \mathrm{NH} 2+\mathrm{CH} 3}$ \\
\hline 198. & $\mathrm{CH}_{3} \mathrm{NHCH}_{3}+\mathrm{NH}_{2}=\mathrm{CH}_{3} \mathrm{NHCH}_{2}+\mathrm{NH}_{3}$ & $2.8 \mathrm{E} 06$ & 1.940 & 5494 & $\mathrm{k}_{\mathrm{CH} 3 \mathrm{NH} 2+\mathrm{NH} 2}$ \\
\hline 199. & $\mathrm{CH}_{3} \mathrm{NHCH}_{3}+\mathrm{NH}_{2}=\mathrm{CH}_{3} \mathrm{NCH}_{3}+\mathrm{NH}_{3}$ & $1.8 \mathrm{E} 06$ & 1.940 & 7143 & $\mathrm{k}_{\mathrm{CH} 3 \mathrm{NH} 2+\mathrm{NH} 2}$ \\
\hline 200. & $\mathrm{CH}_{3} \mathrm{NHCH}_{2}=\mathrm{CH}_{3}+\mathrm{CH}_{2} \mathrm{NH}$ & $9.8 \mathrm{E} 43$ & -10.302 & 37459 & $\mathrm{pw}^{\mathrm{a}}$ \\
\hline 201. & $\mathrm{CH}_{3} \mathrm{NHCH}_{2}=\mathrm{CH}_{3} \mathrm{NCH}_{2}+\mathrm{H}$ & $5.9 \mathrm{E} 44$ & -10.314 & 46803 & $\mathrm{pw}^{\mathrm{a}}$ \\
\hline 202. & $\mathrm{CH}_{3} \mathrm{NHCH}_{2}+\mathrm{H}=\mathrm{CH}_{3} \mathrm{NCH}_{2}+\mathrm{H}_{2}$ & $4.8 \mathrm{E} 08$ & 1.500 & -894 & $\mathrm{k}_{\mathrm{CH} 2 \mathrm{NH} 2+\mathrm{H}}$ \\
\hline 203. & $\mathrm{CH}_{3} \mathrm{NHCH}_{2}+\mathrm{O}=\mathrm{CH}_{3} \mathrm{NH}+\mathrm{CH}_{2} \mathrm{O}$ & $7.0 \mathrm{E} 13$ & 0.000 & 0 & $\mathrm{k}_{\mathrm{CH} 2 \mathrm{NH} 2+\mathrm{O}}$ \\
\hline 204. & $\mathrm{CH}_{3} \mathrm{NHCH}_{2}+\mathrm{O}=\mathrm{CH}_{3} \mathrm{NCH}_{2}+\mathrm{OH}$ & $3.3 \mathrm{E} 08$ & 1.500 & -894 & $\mathrm{k}_{\mathrm{CH} 2 \mathrm{NH} 2+\mathrm{O}}$ \\
\hline 205. & $\mathrm{CH}_{3} \mathrm{NHCH}_{2}+\mathrm{OH}=\mathrm{CH}_{3} \mathrm{NH}+\mathrm{CH}_{2} \mathrm{OH}$ & $4.0 \mathrm{E} 13$ & 0.000 & 0 & $\mathrm{k}_{\mathrm{CH} 2 \mathrm{NH} 2+\mathrm{OH}}$ \\
\hline 206. & $\mathrm{CH}_{3} \mathrm{NHCH}_{2}+\mathrm{OH}=\mathrm{CH}_{3} \mathrm{NCH}_{2}+\mathrm{H}_{2} \mathrm{O}$ & $2.4 \mathrm{E} 06$ & 2.000 & -1192 & $\mathrm{k}_{\mathrm{CH} 2 \mathrm{NH} 2+\mathrm{OH}}$ \\
\hline 207. & $\mathrm{CH}_{3} \mathrm{NHCH}_{2}+\mathrm{CH}_{3}=\mathrm{C}_{2} \mathrm{H}_{5}+\mathrm{CH}_{3} \mathrm{NH}$ & $2.0 \mathrm{E} 13$ & 0.000 & 2702 & $\mathrm{k}_{\mathrm{CH} 2 \mathrm{NH} 2+\mathrm{CH} 3}$ \\
\hline 208. & $\mathrm{CH}_{3} \mathrm{NHCH}_{2}+\mathrm{CH}_{3}=\mathrm{CH}_{3} \mathrm{NCH}_{2}+\mathrm{CH}_{4}$ & $1.6 \mathrm{E} 06$ & 1.870 & -626 & $\mathrm{k}_{\mathrm{CH} 2 \mathrm{NH} 2+\mathrm{CH} 3}$ \\
\hline 209. & $\mathrm{CH}_{3} \mathrm{NCH}_{3}=\mathrm{CH}_{3} \mathrm{NCH}_{2}+\mathrm{H}$ & $1.6 \mathrm{E} 15$ & -7.544 & 38425 & $\mathrm{pw}^{\mathrm{a}}$ \\
\hline 210. & $\mathrm{CH}_{3} \mathrm{NCH}_{3}+\mathrm{H}=\mathrm{CH}_{3} \mathrm{NCH}_{2}+\mathrm{H}_{2}$ & $3.2 \mathrm{E} 12$ & 0.000 & 0 & $\mathrm{k}_{\mathrm{i}-\mathrm{C} 3 \mathrm{H} 7+\mathrm{H}}$ \\
\hline 211. & $\mathrm{CH}_{3} \mathrm{NCH}_{3}+\mathrm{O}=\mathrm{CH}_{3} \mathrm{NO}+\mathrm{CH}_{3}$ & $5.0 \mathrm{E} 13$ & 0.000 & 0 & est. \\
\hline 212. & $\mathrm{CH}_{3} \mathrm{NCH}_{3}+\mathrm{OH}=\mathrm{CH}_{3} \mathrm{NCH}_{2}+\mathrm{H}_{2} \mathrm{O}$ & $2.4 \mathrm{E} 13$ & 0.000 & 0 & $\mathrm{k}_{\mathrm{i}-\mathrm{C} 3 \mathrm{H} 7+\mathrm{OH}}$ \\
\hline 213. & $\mathrm{CH}_{3} \mathrm{NCH}_{3}+\mathrm{O}_{2}=\mathrm{CH}_{3} \mathrm{NO}+\mathrm{CH}_{3} \mathrm{O}$ & $1.0 \mathrm{E} 09$ & 1.000 & 6000 & [77], est. \\
\hline 214. & $\mathrm{CH}_{3} \mathrm{NCH}_{3}+\mathrm{CH}_{3}=\mathrm{CH}_{3} \mathrm{NCH}_{2}+\mathrm{CH}_{4}$ & $6.0 \mathrm{E} 12$ & 0.000 & 0 & [78] \\
\hline 215. & $\mathrm{CH}_{2} \mathrm{NCH}_{2}+\mathrm{H}=\mathrm{CH}_{3} \mathrm{NCH}_{2}$ & $5.8 \mathrm{E} 13$ & 0.180 & -125 & $\mathrm{k}_{\mathrm{CH} 2 \mathrm{CHCH} 2+\mathrm{H}}$ \\
\hline 216. & $\mathrm{CH}_{3} \mathrm{NCH}_{2}+\mathrm{H}=\mathrm{CH}_{2} \mathrm{NCH}_{2}+\mathrm{H}_{2}$ & $5.6 \mathrm{E} 08$ & 1.500 & 5464 & $\mathrm{k}_{\mathrm{CH} 3 \mathrm{NH} 2+\mathrm{H}}$ \\
\hline 217. & $\mathrm{CH}_{3} \mathrm{NCH}_{2}+\mathrm{H}=\mathrm{CH}_{3} \mathrm{NCH}+\mathrm{H}_{2}$ & $3.0 \mathrm{E} 08$ & 1.500 & 6130 & $\mathrm{k}_{\mathrm{CH} 2 \mathrm{NH}+\mathrm{H}}$ \\
\hline 218. & $\mathrm{CH}_{3} \mathrm{NCH}_{2}+\mathrm{O}=\mathrm{CH}_{2} \mathrm{NCH}_{2}+\mathrm{OH}$ & $4.0 \mathrm{E} 08$ & 1.500 & 5196 & $\mathrm{k}_{\mathrm{CH} 3 \mathrm{NH} 2+\mathrm{O}}$ \\
\hline 219. & $\mathrm{CH}_{3} \mathrm{NCH}_{2}+\mathrm{O}=\mathrm{CH}_{3} \mathrm{NCH}+\mathrm{OH}$ & $2.2 \mathrm{E} 08$ & 1.500 & 5404 & $\mathrm{k}_{\mathrm{CH} 2 \mathrm{NH}+\mathrm{O}}$ \\
\hline 220. & $\mathrm{CH}_{3} \mathrm{NCH}_{2}+\mathrm{OH}=\mathrm{CH}_{2} \mathrm{NCH}_{2}+\mathrm{H}_{2} \mathrm{O}$ & $8.0 \mathrm{E} 12$ & 0.000 & 0 & $\mathrm{k}_{\mathrm{CH} 3 \mathrm{NH} 2+\mathrm{OH}}$ \\
\hline 221. & $\mathrm{CH}_{3} \mathrm{NCH}_{2}+\mathrm{OH}=\mathrm{CH}_{3} \mathrm{NCH}+\mathrm{H}_{2} \mathrm{O}$ & $2.4 \mathrm{E} 06$ & 2.000 & 457 & $\mathrm{k}_{\mathrm{CH} 2 \mathrm{NH}+\mathrm{OH}}$ \\
\hline 222. & $\mathrm{CH}_{3} \mathrm{NCH}_{2}+\mathrm{CH}_{3}=\mathrm{CH}_{2} \mathrm{NCH}_{2}+\mathrm{CH}_{4}$ & $1.5 \mathrm{E} 06$ & 1.870 & 9170 & $\mathrm{k}_{\mathrm{CH} 3 \mathrm{NH} 2+\mathrm{CH} 3}$ \\
\hline 223. & $\mathrm{CH}_{3} \mathrm{NCH}_{2}+\mathrm{CH}_{3}=\mathrm{CH}_{3} \mathrm{NCH}+\mathrm{CH}_{4}$ & $5.3 \mathrm{E} 05$ & 1.870 & 9687 & $\mathrm{k}_{\mathrm{CH} 2 \mathrm{NH}+\mathrm{CH} 3}$ \\
\hline 224. & $\mathrm{CH}_{3} \mathrm{NCH}_{2}+\mathrm{NH}_{2}=\mathrm{CH}_{2} \mathrm{NCH}_{2}+\mathrm{NH}_{3}$ & $2.8 \mathrm{E} 06$ & 1.940 & 5494 & $\mathrm{k}_{\mathrm{CH} 3 \mathrm{NH} 2+\mathrm{NH} 2}$ \\
\hline 225. & $\mathrm{CH}_{3} \mathrm{NCH}_{2}+\mathrm{NH}_{2}=\mathrm{CH}_{3} \mathrm{NCH}+\mathrm{NH}_{3}$ & $1.8 \mathrm{E} 06$ & 1.940 & 6090 & $\mathrm{k}_{\mathrm{CH} 2 \mathrm{NH}+\mathrm{NH} 2}$ \\
\hline 226. & $\mathrm{CH}_{2} \mathrm{NCH}_{2}=\mathrm{CH}_{3} \mathrm{NCH}$ & $1.3 \mathrm{E} 45$ & -10.068 & 66111 & $\mathrm{pw}^{\mathrm{a}}$ \\
\hline 227. & $\mathrm{CH}_{2} \mathrm{NCH}_{2}+\mathrm{H}=\mathrm{CH}_{3}+\mathrm{H}_{2} \mathrm{CN}$ & $3.0 \mathrm{E} 13$ & 0.000 & 0 & est. \\
\hline 228. & $\mathrm{CH}_{2} \mathrm{NCH}_{2}+\mathrm{O}=\mathrm{CH}_{2} \mathrm{O}+\mathrm{H}_{2} \mathrm{CN}$ & $3.0 \mathrm{E} 13$ & 0.000 & 0 & est. \\
\hline 229. & $\mathrm{CH}_{2} \mathrm{NCH}_{2}+\mathrm{OH}=\mathrm{CH}_{2} \mathrm{OH}+\mathrm{H}_{2} \mathrm{CN}$ & $2.0 \mathrm{E} 13$ & 0.000 & 0 & est. \\
\hline
\end{tabular}




\begin{tabular}{|l|l|c|r|c|l|}
\hline 230. & $\mathrm{CH}_{3} \mathrm{NCH}=\mathrm{CH}_{3}+\mathrm{HCN}$ & $8.1 \mathrm{E} 15$ & -2.375 & 14942 & $\mathrm{pw}^{\mathrm{a}}$ \\
\hline 231. & $\mathrm{CH}_{3} \mathrm{NCH}+\mathrm{H}=\mathrm{CH}_{2} \mathrm{NCH}_{2}+\mathrm{H}$ & $2.0 \mathrm{E} 13$ & 0.000 & 0 & $\mathrm{k}_{\mathrm{HCNH}+\mathrm{H}}$ \\
\hline 232. & $\mathrm{CH}_{3} \mathrm{NCH}+\mathrm{O}=>\mathrm{CH}_{3}+\mathrm{NCO}+\mathrm{H}$ & $7.0 \mathrm{E} 13$ & 0.000 & 0 & $\mathrm{k}_{\mathrm{HCNH}+\mathrm{O}}$ \\
\hline
\end{tabular}

a: 0.04 bar, $700-2500 \mathrm{~K}$

pw: present work 


\section{Figure Captions}

Fig. 1: Proposed destruction pathways for ethylamine (top) and dimethylamine fuel (bottom). The exact masses are indicated below the respective species, and selected bond dissociation energies derived via quantum chemistry are denoted in bold characters near the arrow for the respective reaction steps. Species highlighted in grey were detected in the experiment.

Fig. 2: Major species and temperature profiles in the three investigated ethylamine (EA) flames; EA08 is $\Phi=0.8$, EA10 is $\Phi=1.0$, EA13 is $\Phi=1.3$. Symbols are experimental mole fractions, and corresponding lines represent simulations. Equilibrium values are marked as open symbols at $33 \mathrm{~mm}$, and temperature is given as thin black lines.

Fig. 3: Major species and temperature profiles in the three investigated dimethylamine (DMA) flames; DMA08 is $\Phi=0.8$, DMA10 is $\Phi=1.0$, DMA13 is $\Phi=1.3$. Symbols are experimental mole fractions, and corresponding lines represent simulations. Equilibrium values are marked as open symbols at $33 \mathrm{~mm}$, and temperature is given as thin black lines.

Fig. 4: $\mathrm{NO}$ and $\mathrm{N}_{2}$ mole fraction profiles. a) $\mathrm{NO}$ from experiment in the six flames, b) and c) comparison of experiment and model for $\mathrm{NO}$ and $\mathrm{N}_{2}$ in the stoichiometric EA and DMA flames. Equilibrium values are marked as open symbols at $33 \mathrm{~mm}$.

Fig 5: Mole fraction profiles of $\mathrm{C}_{2} \mathrm{H}_{6} \mathrm{~N}$ from experiment (symbols) and simulation (lines). Top: sum of all isomers. Bottom: comparison of isomers from the model with experiment for $\Phi=1.0$; for the experimental values, upper and lower limits of fragmentation corrections have been applied.

Fig. 6: Mole fraction profiles of $\mathrm{C}_{2} \mathrm{H}_{5} \mathrm{~N}$ from experiment (symbols) and simulation (lines). 
Fig. 7: Mole fraction profiles of $\mathrm{C}_{2} \mathrm{H}_{4} \mathrm{~N}$ from experiment (symbols) and simulation (lines). Top: sum of all isomers. Bottom: comparison of isomers from the model with experiment for $\Phi=1.0$; for the experimental values, upper and lower limits of fragmentation corrections have been applied.

Fig. 8: Mole fraction profiles of $\mathrm{C}_{2} \mathrm{H}_{3} \mathrm{~N}$ from experiment (symbols) and simulation (lines).

Fig. 9: Photoionization efficiency curves at $m / z=41$ in the fuel-rich ethylamine and dimethylamine flames.

Fig. 10: Mole fraction profiles of $\mathrm{C}_{2} \mathrm{H}_{3} \mathrm{~N}$ isomers in the fuel-rich flames from experiment (symbols) and simulation (lines).

Fig. 11: Mole fraction profiles of $\mathrm{CH}_{2} \mathrm{NH}$, methanimine, (top) and $\mathrm{CH}_{2} \mathrm{~N}$ (bottom) from experiment (symbols) and simulation (lines); the sum of $\mathrm{CH}_{2} \mathrm{~N}$ isomers from the EI-MBMS experiment is compared with the sum of $\mathrm{H}_{2} \mathrm{CN}$ and $\mathrm{HCNH}$ in the simulations.

Fig. 12: Mole fraction profiles of $\mathrm{NH}_{3}$ (top) and $\mathrm{HCN}$ (bottom) from experiment (symbols) and simulation (lines).

Fig. 13: Reaction flux diagram for the stoichiometric ethylamine flame. Broad arrows represent contributions of $\geq 40 \%$, light arrows those with $<40 \%$.

Fig. 14: Reaction flux diagram for the stoichiometric dimethylamine flame. Broad arrows represent contributions of $\geq 40 \%$, light arrows those with $<40 \%$. 
Fig. 15: Mole fraction profiles of $\mathrm{CHNO}$ species (top) and $\mathrm{NO}_{2}$ (bottom) from experiment (symbols) and simulation (lines).

Fig. 16: Reaction flux analysis in the stoichiometric EA (left) and DMA (right) flames, presented for $\mathrm{NH}_{3}$ (top) and $\mathrm{NO}$ (bottom); consumption (negative bars) and formation (positive bars) reactions with contributions $>10 \%$ are indicated.

Fig. 17: Mole fraction profiles of $\mathrm{CH}_{3}$ (top) and $\mathrm{CH}_{4}$ (bottom) from experiment (symbols) and simulation (lines).

Fig. 18: Mole fraction profiles of $\mathrm{C}_{2} \mathrm{H}_{2}$ (top) and $\mathrm{C}_{2} \mathrm{H}_{4}$ (bottom) from experiment (symbols) and simulation (lines).

Fig. 19: Mole fraction profiles of $\mathrm{CH}_{3} \mathrm{OH}$ (top) and $\mathrm{CH}_{2} \mathrm{O}$ (bottom) from experiment (symbols) and simulation (lines). 
Fig. 1: Proposed destruction pathways for ethylamine (top) and dimethylamine fuel (bottom). The exact masses are indicated below the respective species, and selected bond dissociation energies derived via quantum chemistry are denoted in bold characters near the arrow for the respective reaction steps. Species highlighted in grey were detected in the experiment.
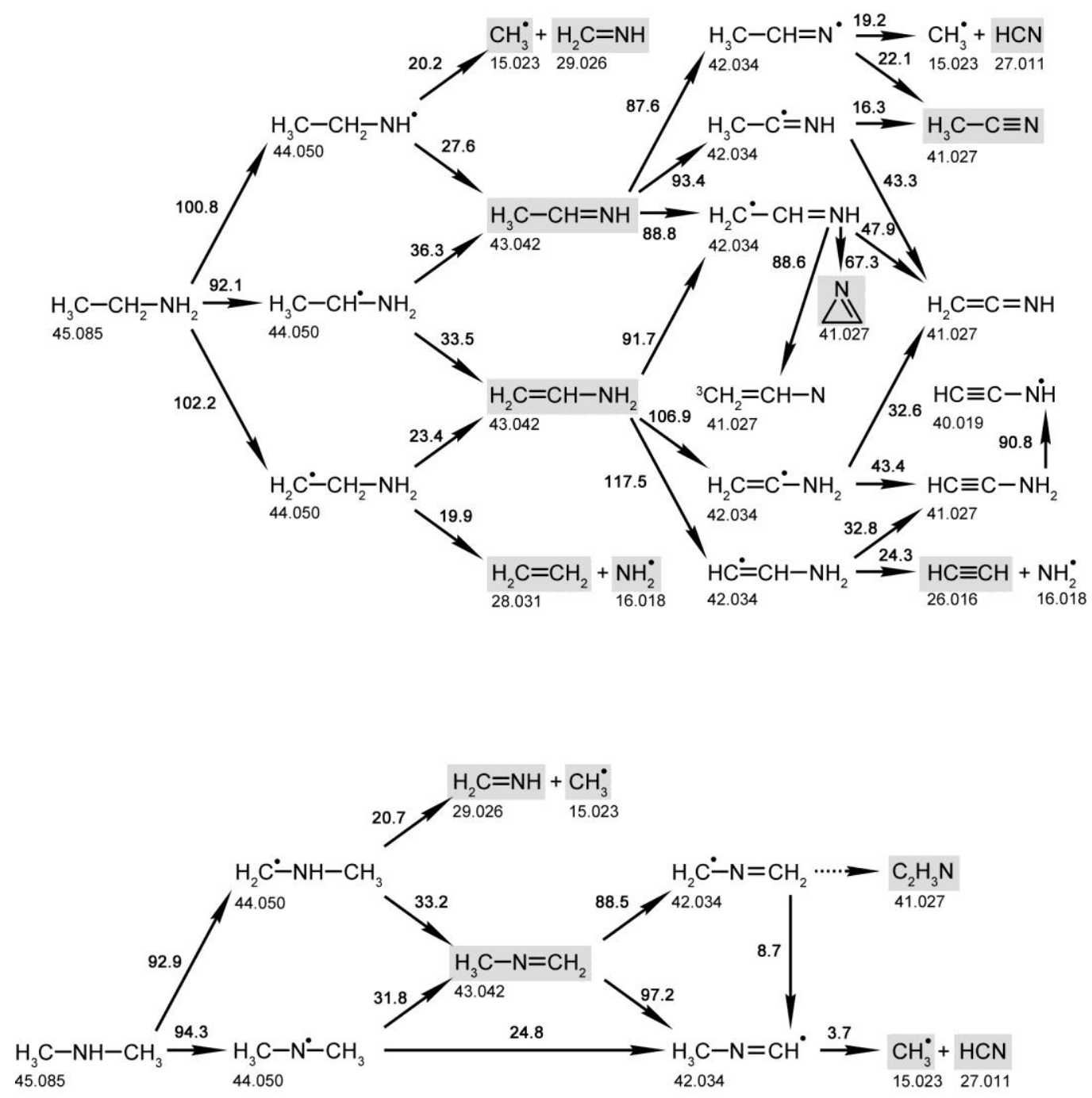
Fig. 2: Major species and temperature profiles in the three investigated ethylamine (EA) flames; EA08 is $\Phi=0.8$, EA10 is $\Phi=1.0$, EA13 is $\Phi=1.3$. Symbols are experimental mole fractions, and corresponding lines represent simulations. Equilibrium values are marked as open symbols at $33 \mathrm{~mm}$, and temperature is given as thin black lines.
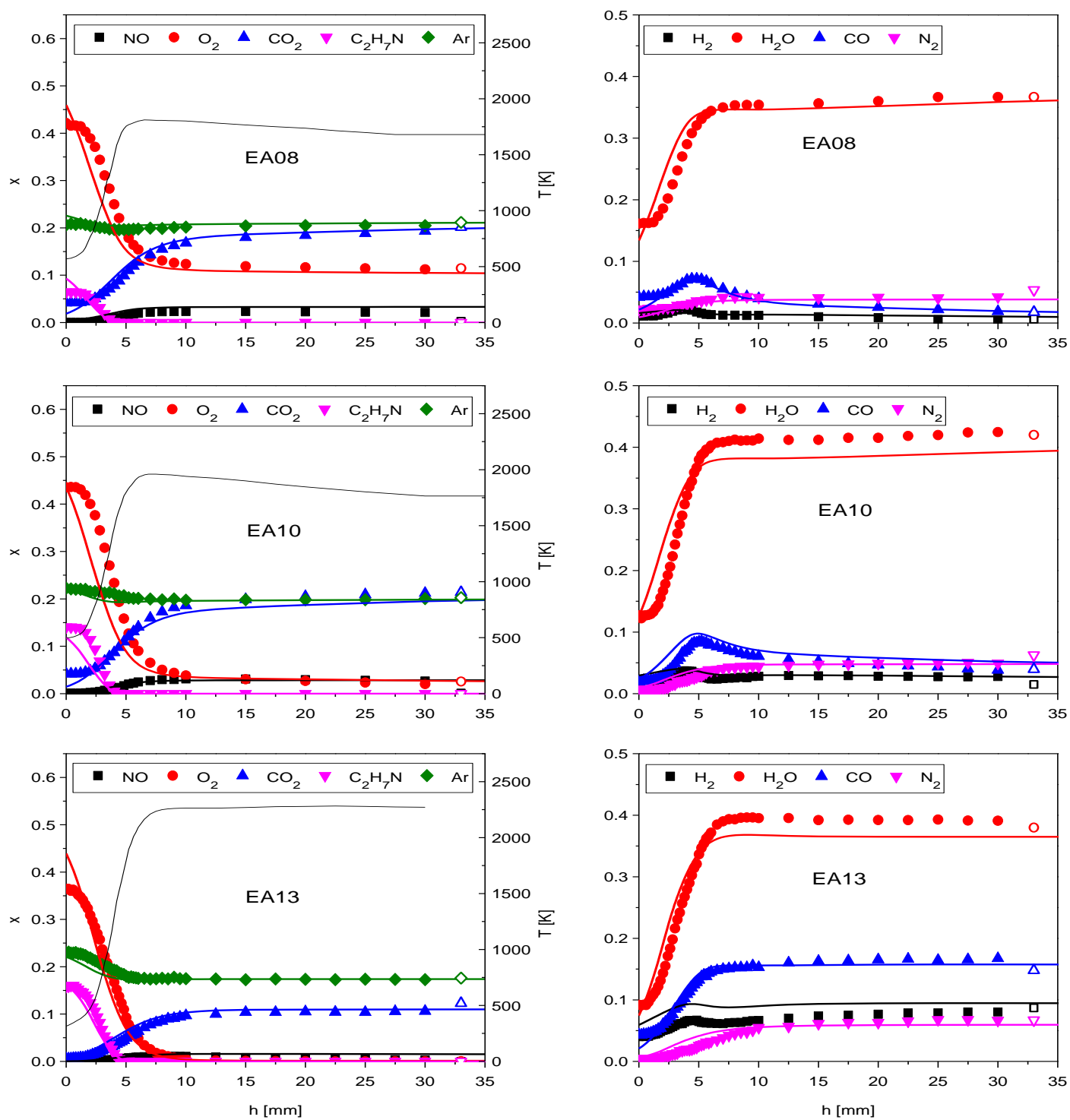
Fig. 3: Major species and temperature profiles in the three investigated dimethylamine (DMA) flames; DMA08 is $\Phi=0.8$, DMA10 is $\Phi=1.0$, DMA13 is $\Phi=1.3$. Symbols are experimental mole fractions, and corresponding lines represent simulations. Equilibrium values are marked as open symbols at $33 \mathrm{~mm}$, and temperature is given as thin black lines.
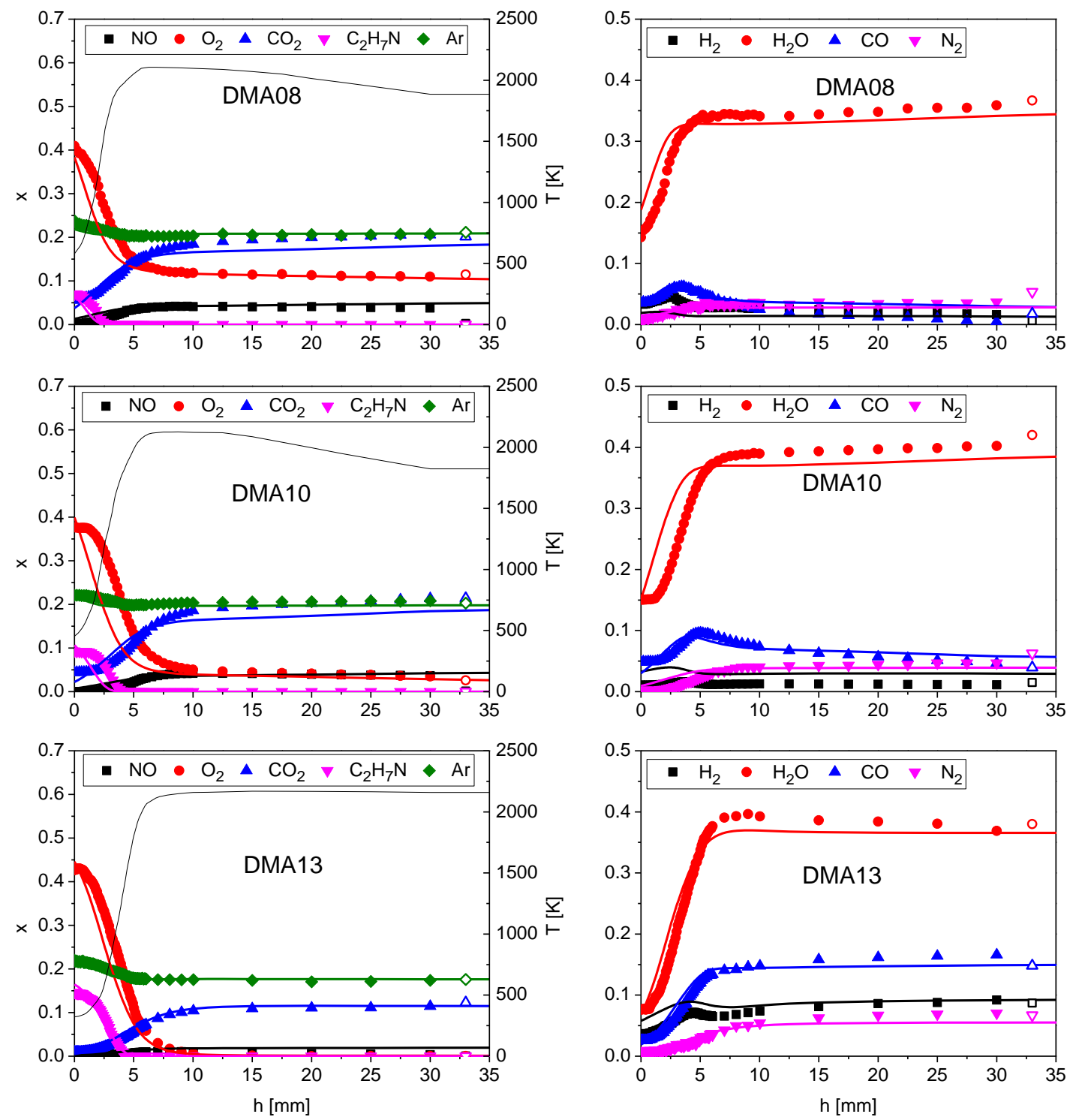
Fig. 4: $\mathrm{NO}$ and $\mathrm{N}_{2}$ mole fraction profiles. a) $\mathrm{NO}$ from experiment in the six flames,b) and $c$ ) comparison of experiment and model for $\mathrm{NO}$ and $\mathrm{N}_{2}$ in the stoichiometric EA and DMA flames. Equilibrium values are marked as open symbols at $33 \mathrm{~mm}$.
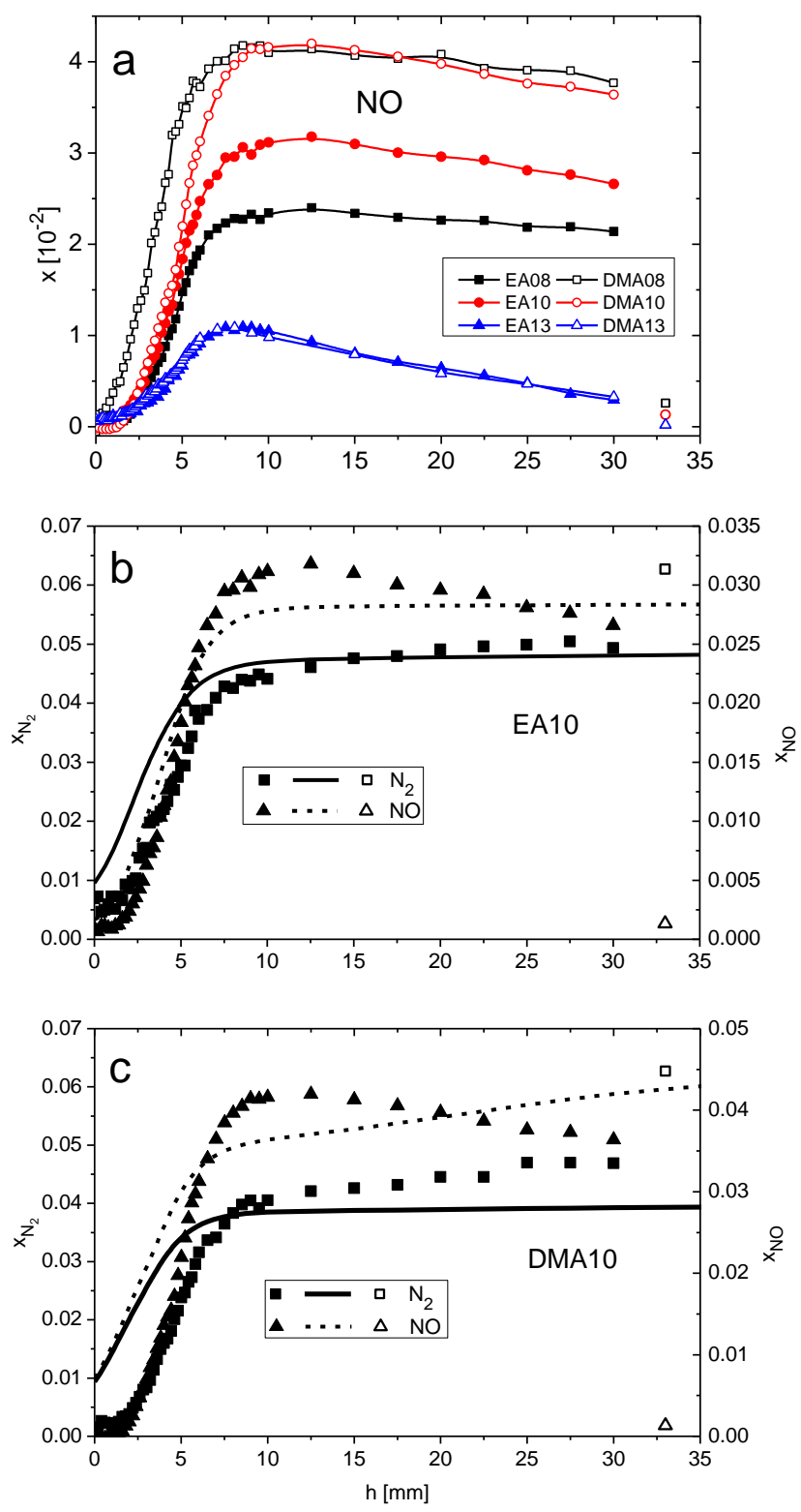
Fig 5: Mole fraction profiles of $\mathrm{C}_{2} \mathrm{H}_{6} \mathrm{~N}$ from experiment (symbols) and simulation (lines). Top: sum of all isomers. Bottom: comparison of isomers from the model with experiment for $\Phi=1.0$; for the experimental values, upper and lower limits of fragmentation corrections have been applied.
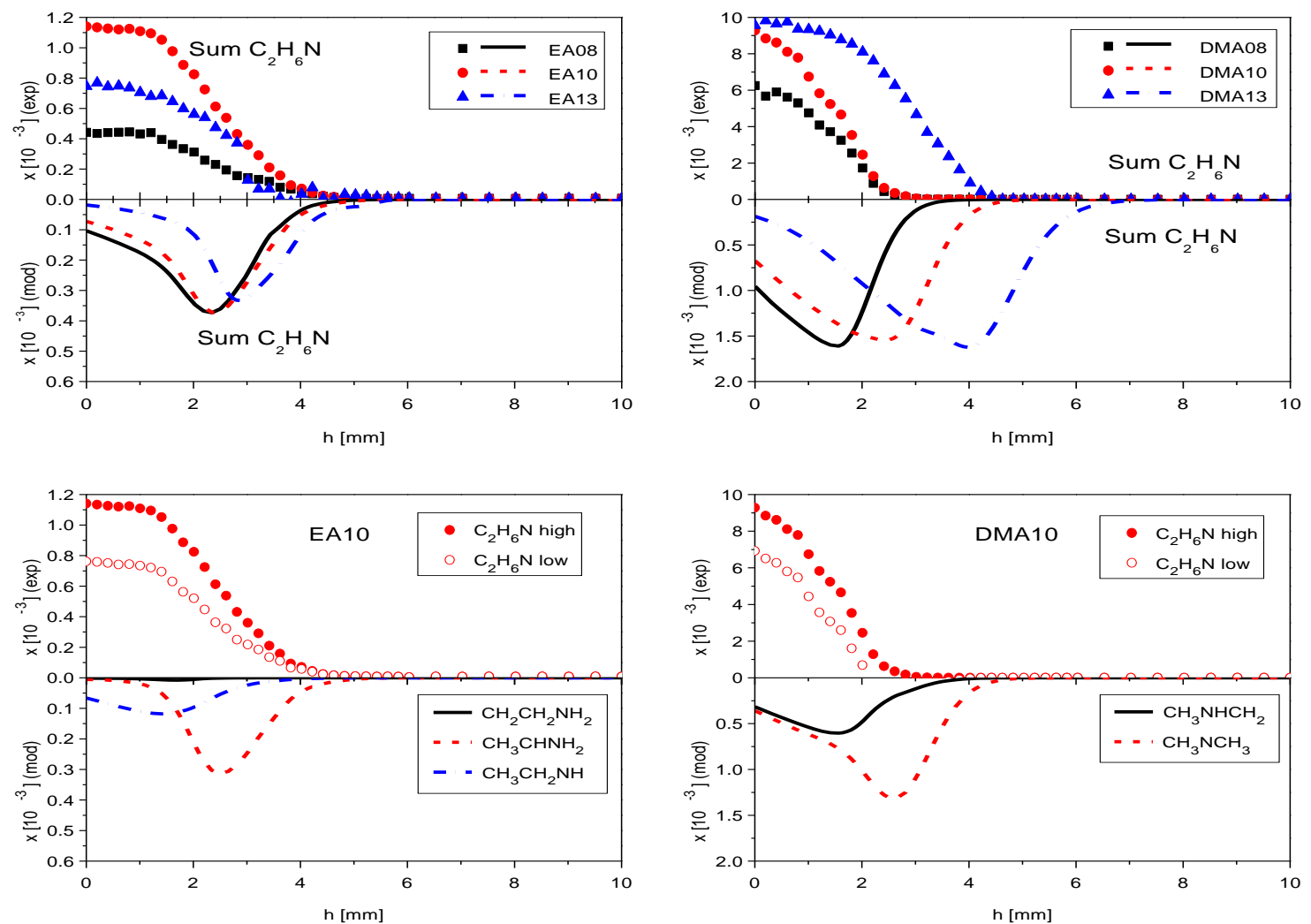
Fig. 6: Mole fraction profiles of $\mathrm{C}_{2} \mathrm{H}_{5} \mathrm{~N}$ from experiment (symbols) and simulation (lines).
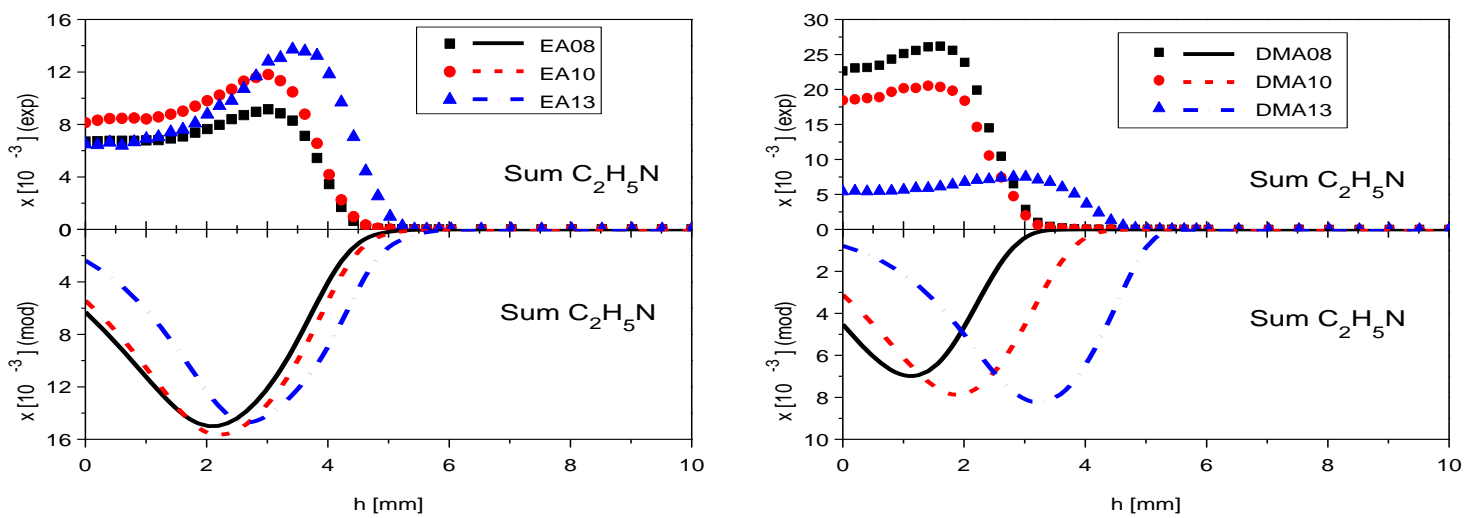
Fig. 7: Mole fraction profiles of $\mathrm{C}_{2} \mathrm{H}_{4} \mathrm{~N}$ from experiment (symbols) and simulation (lines).

Top: sum of all isomers. Bottom: comparison of isomers from the model with experiment for $\Phi=1.0$; for the experimental values, upper and lower limits of fragmentation corrections have been applied.
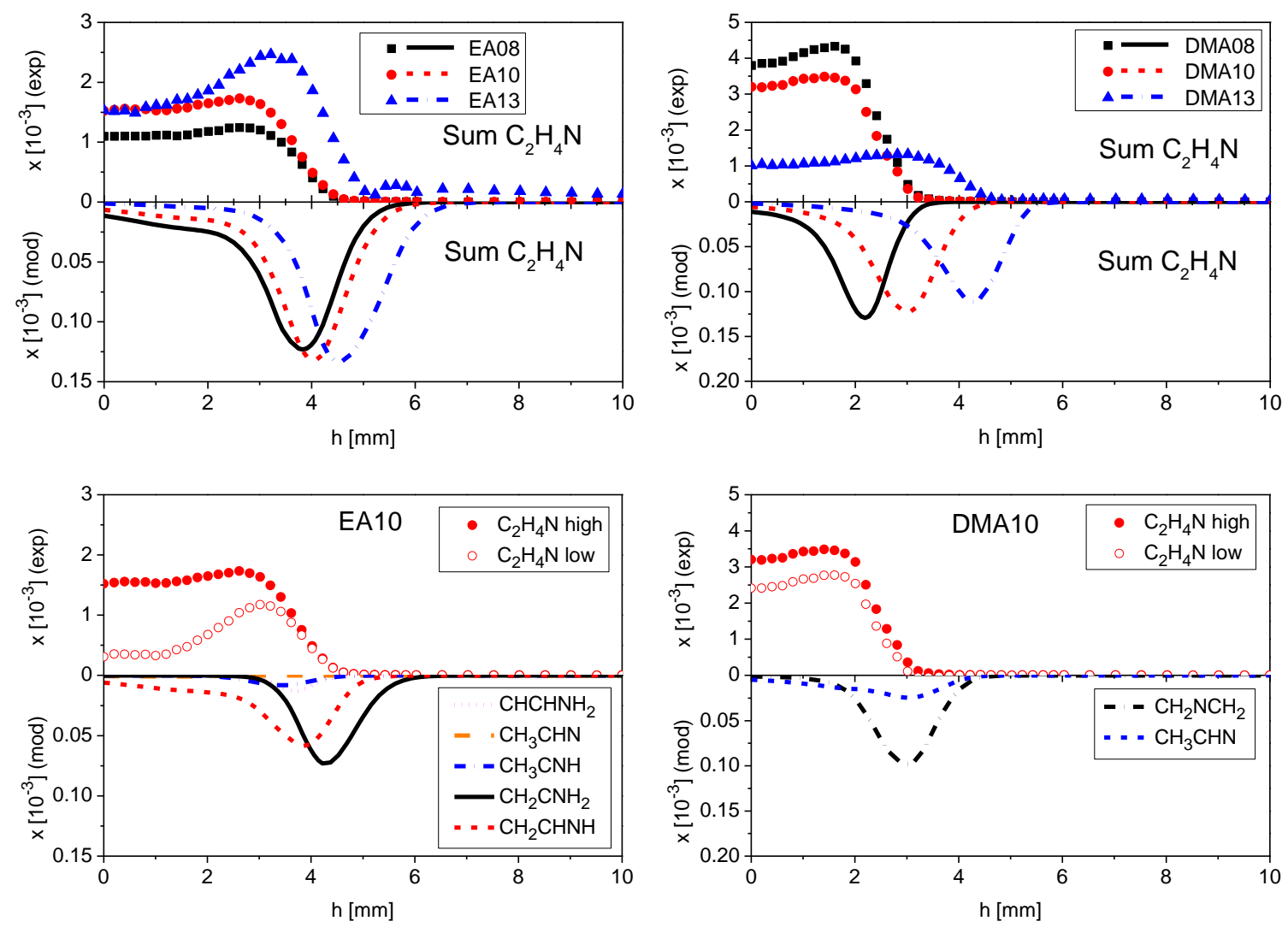
Fig. 8: Mole fraction profiles of $\mathrm{C}_{2} \mathrm{H}_{3} \mathrm{~N}$ from experiment (symbols) and simulation (lines).
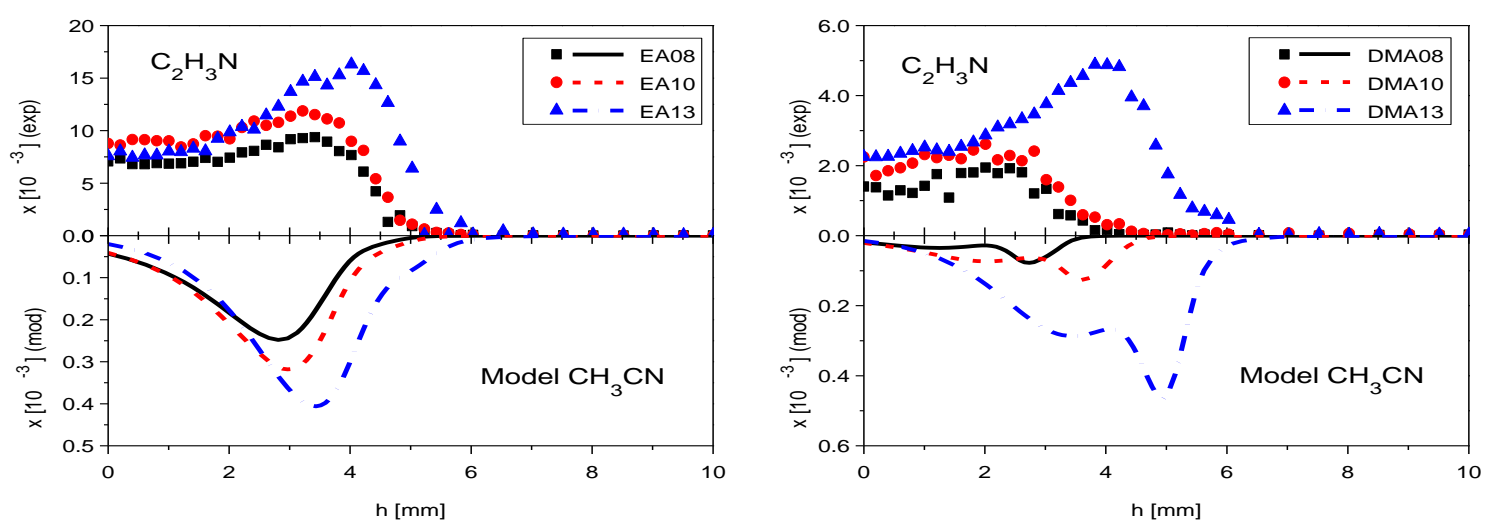
Fig. 9: Photoionization efficiency curves at $m / z=41$ in the fuel-rich ethylamine and dimethylamine flames.
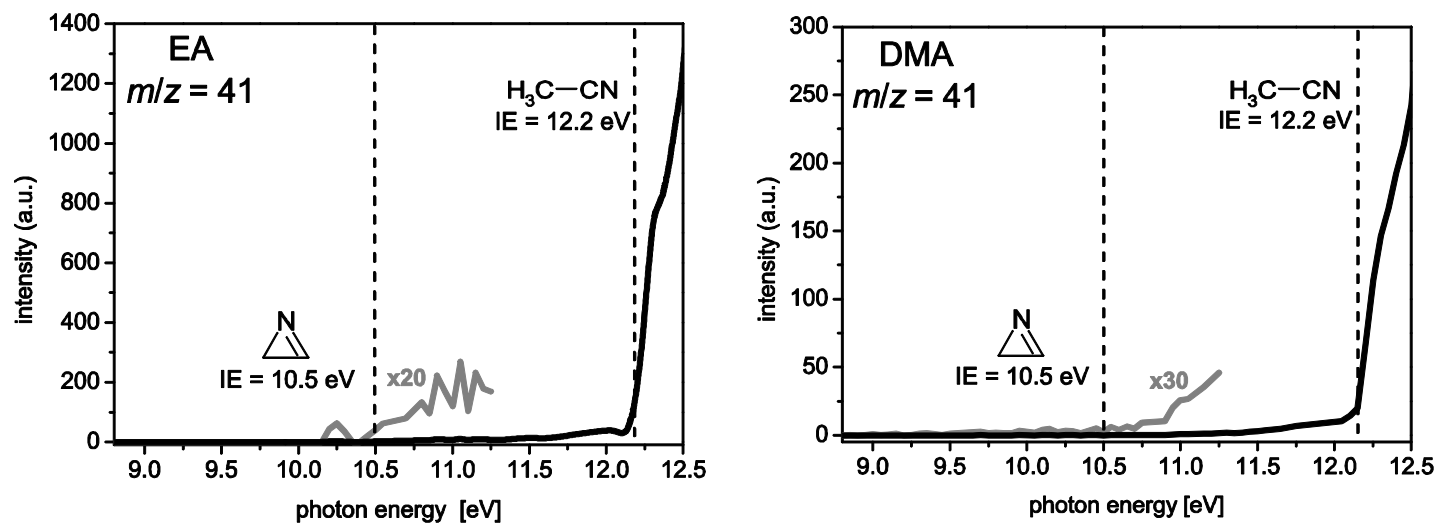
Fig. 10: Mole fraction profiles of $\mathrm{C}_{2} \mathrm{H}_{3} \mathrm{~N}$ isomers in the fuel-rich flames from experiment (symbols) and simulation (lines).
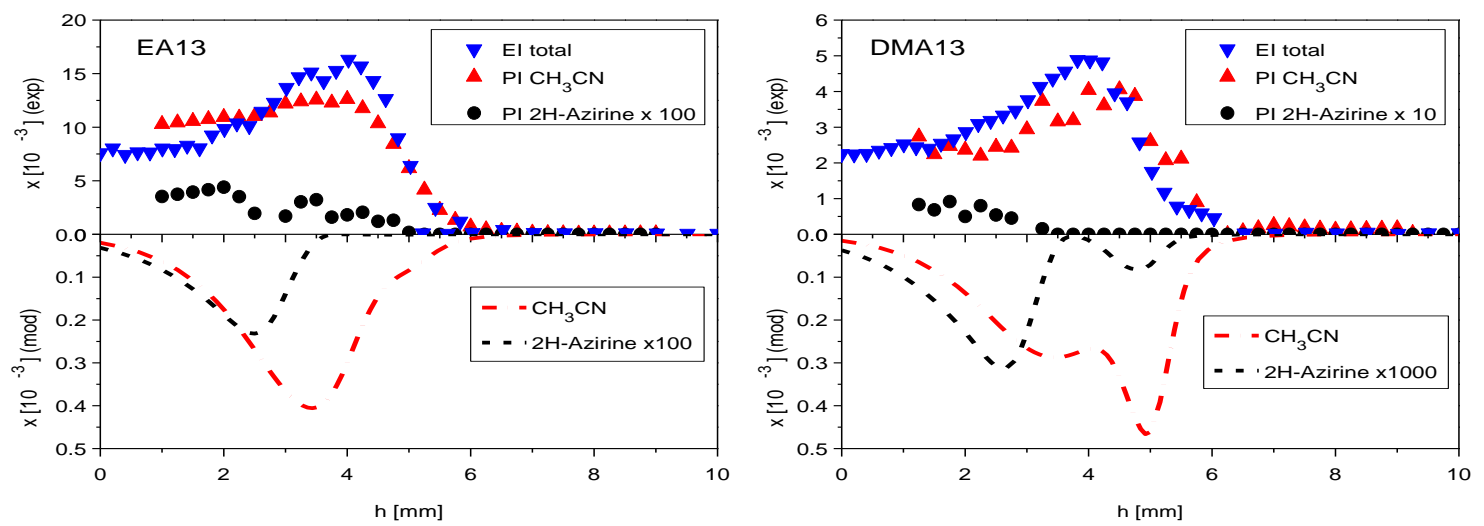
Fig. 11: Mole fraction profiles of $\mathrm{CH}_{2} \mathrm{NH}$, methanimine, (top) and $\mathrm{CH}_{2} \mathrm{~N}$ (bottom) from experiment (symbols) and simulation (lines); the sum of $\mathrm{CH}_{2} \mathrm{~N}$ isomers from the EI-MBMS experiment is compared with the sum of $\mathrm{H}_{2} \mathrm{CN}$ and $\mathrm{HCNH}$ in the simulations.
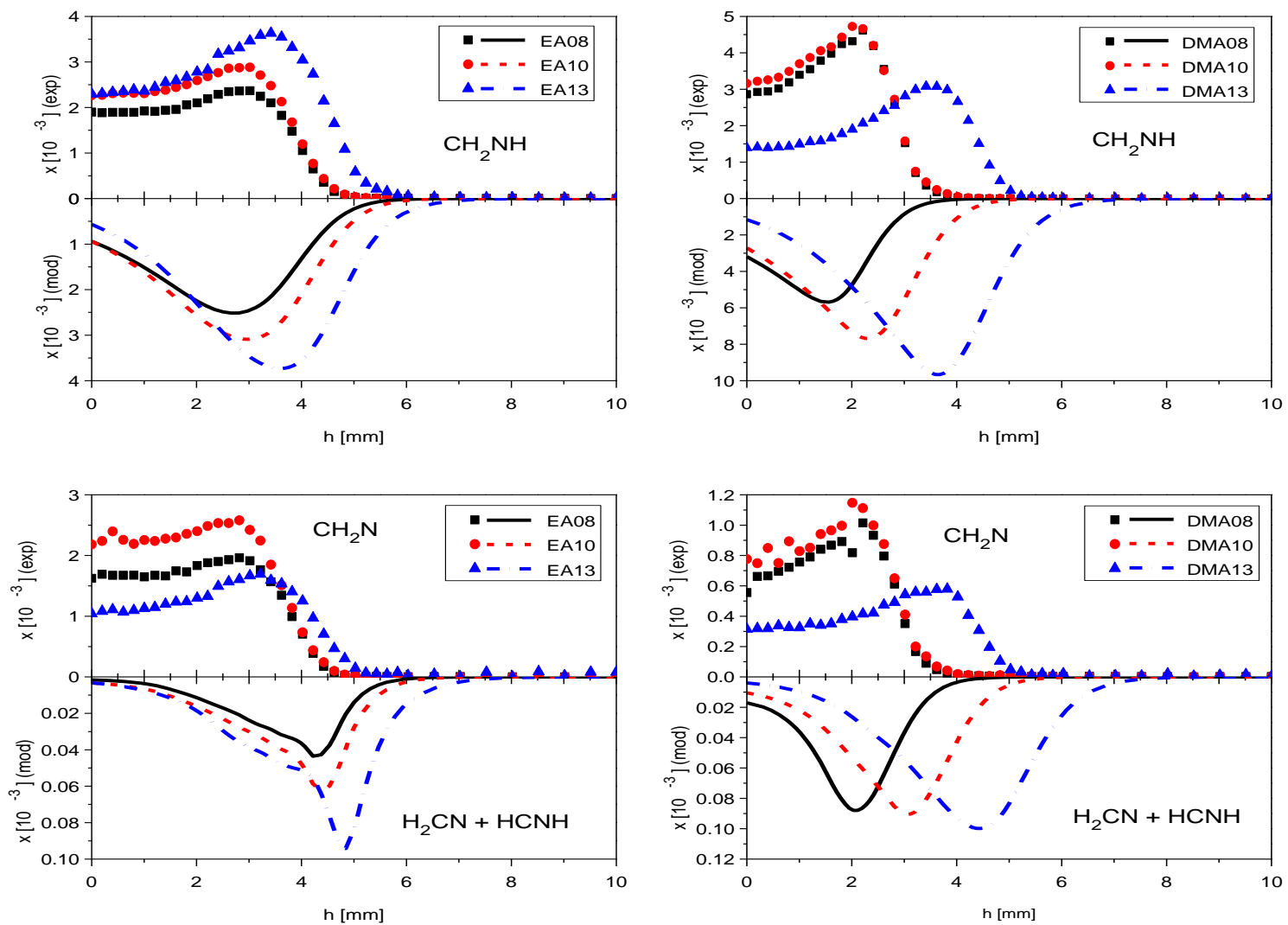
Fig. 12: Mole fraction profiles of $\mathrm{NH}_{3}$ (top) and $\mathrm{HCN}$ (bottom) from experiment (symbols) and simulation (lines).
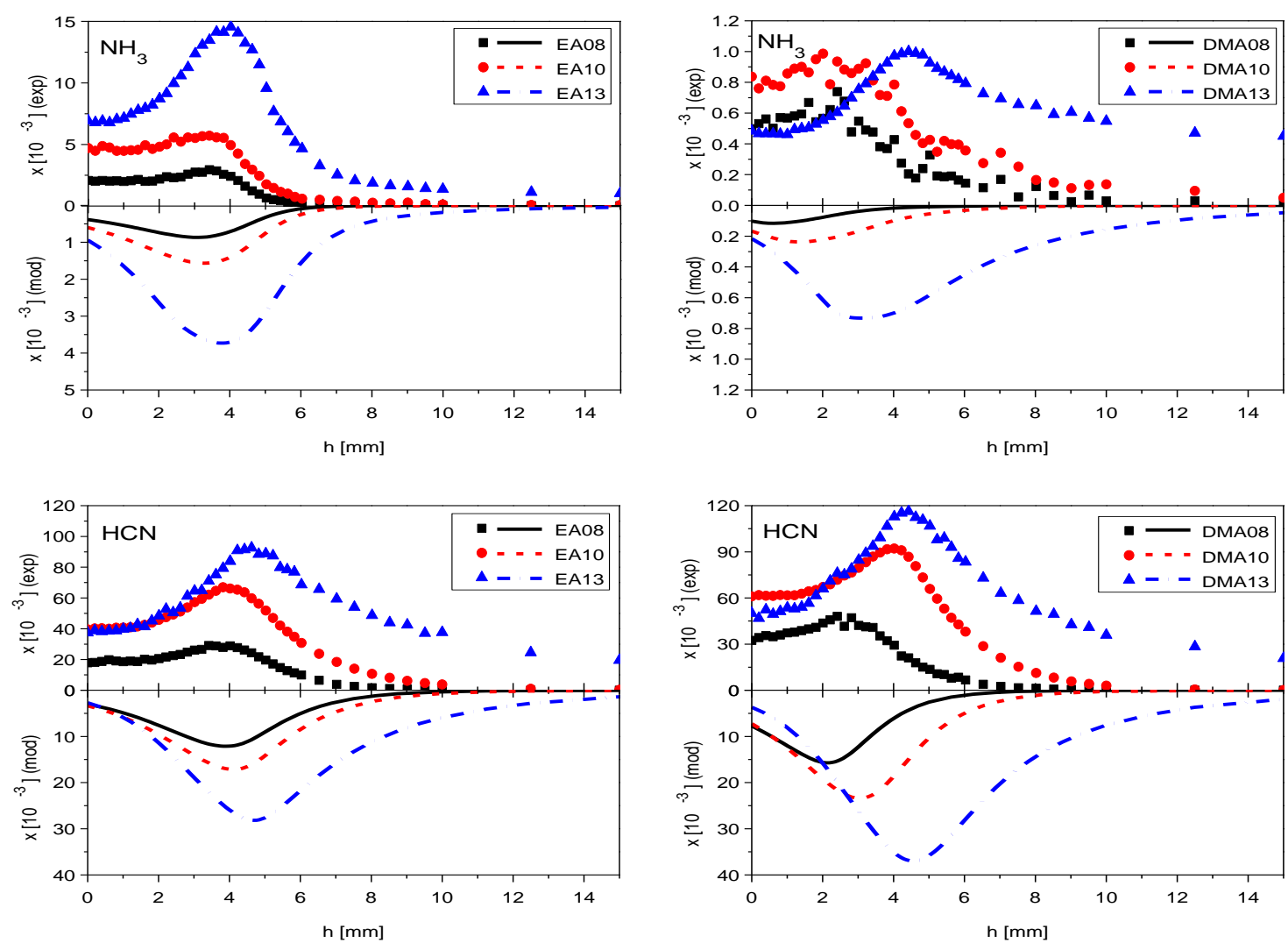
Fig. 13: Reaction flux diagram for the stoichiometric ethylamine flame. Broad arrows represent contributions of $\geq 40 \%$, light arrows those with $<40 \%$.

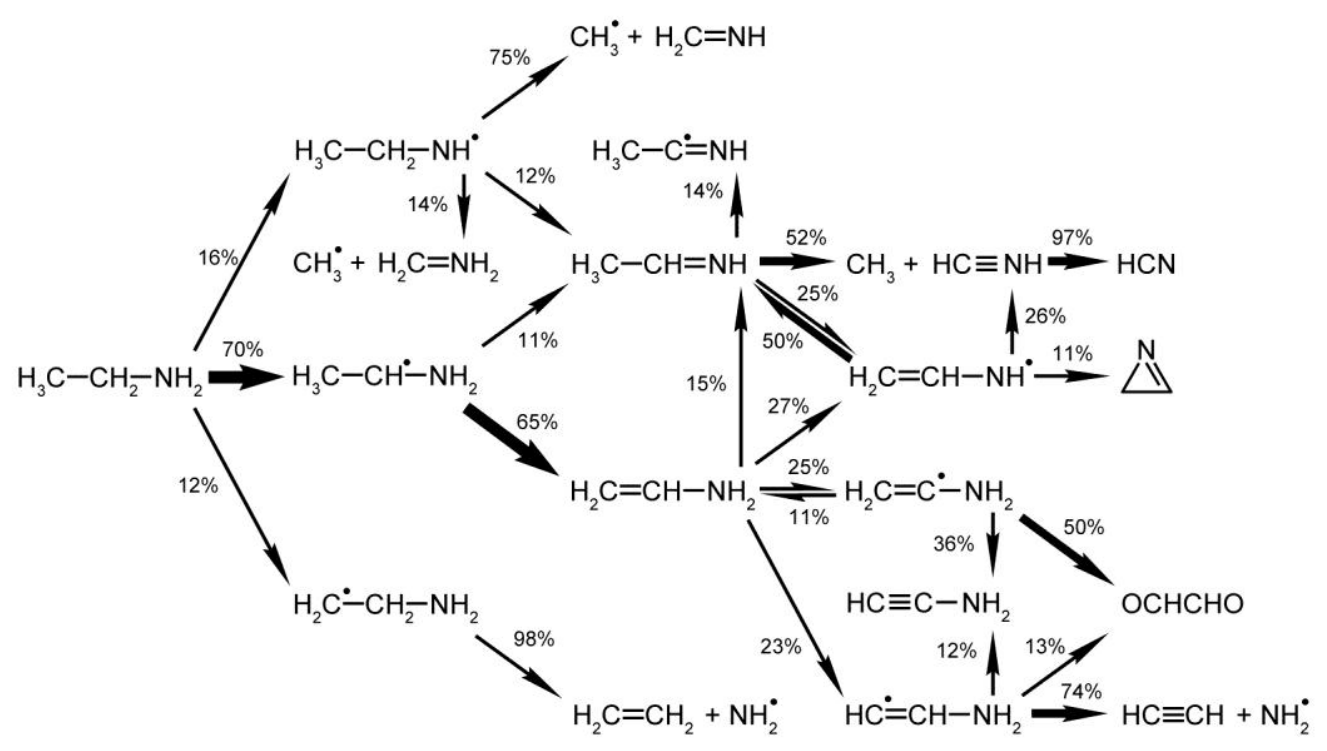


Fig. 14: Reaction flux diagram for the stoichiometric dimethylamine flame. Broad arrows represent contributions of $\geq 40 \%$, light arrows those with $<40 \%$.

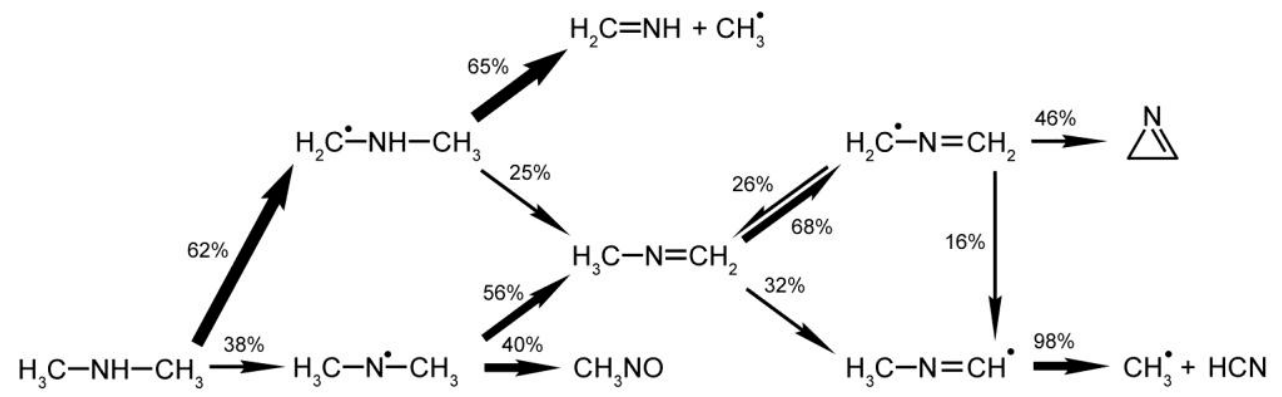


Fig. 15: Mole fraction profiles of $\mathrm{CHNO}$ species (top) and $\mathrm{NO}_{2}$ (bottom) from experiment (symbols) and simulation (lines).
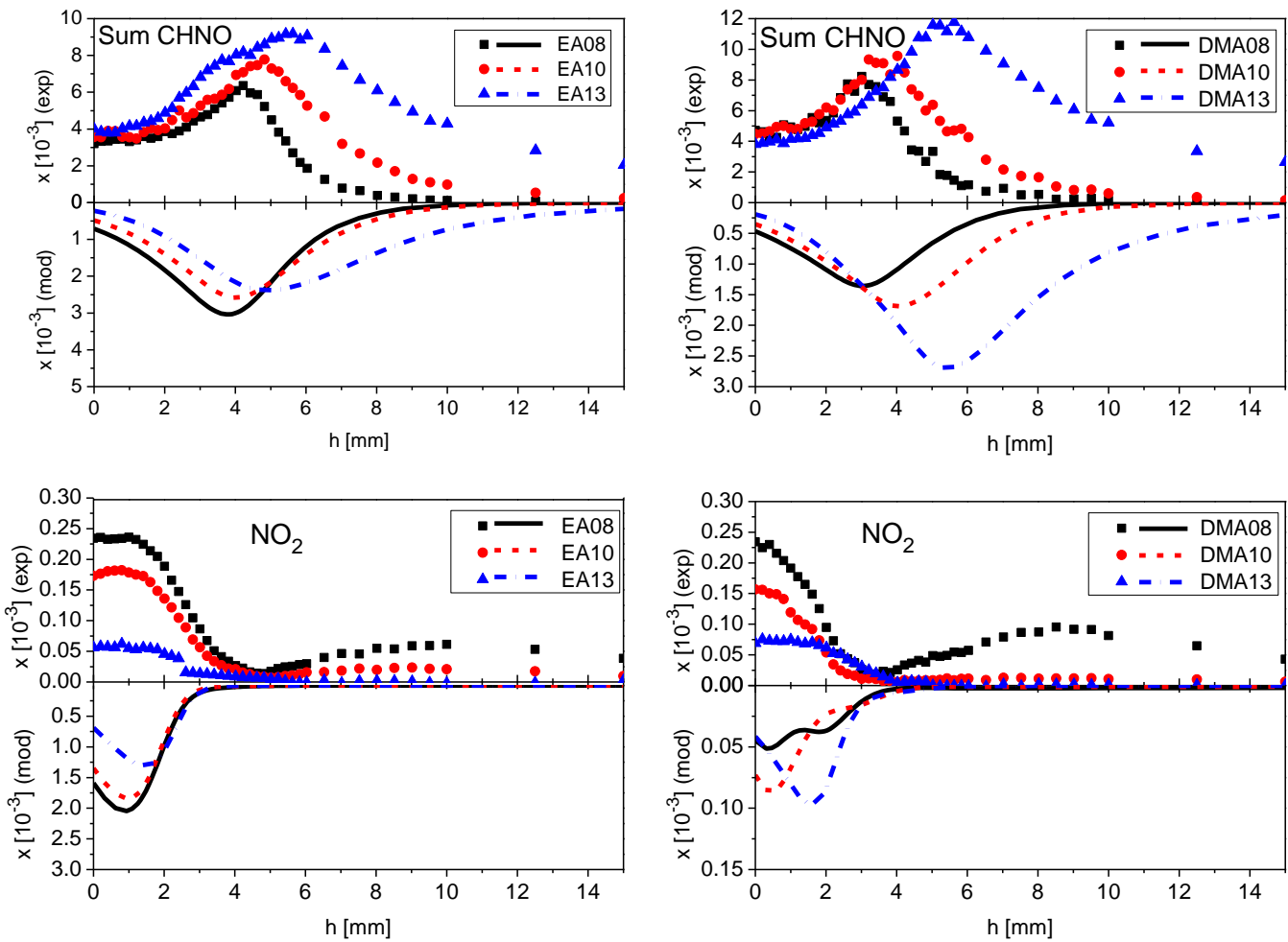
Fig. 16: Reaction flux analysis in the stoichiometric EA (left) and DMA (right) flames, presented for $\mathrm{NH}_{3}$ (top) and $\mathrm{NO}$ (bottom); consumption (negative bars) and formation (positive bars) reactions with contributions $>10 \%$ are indicated.
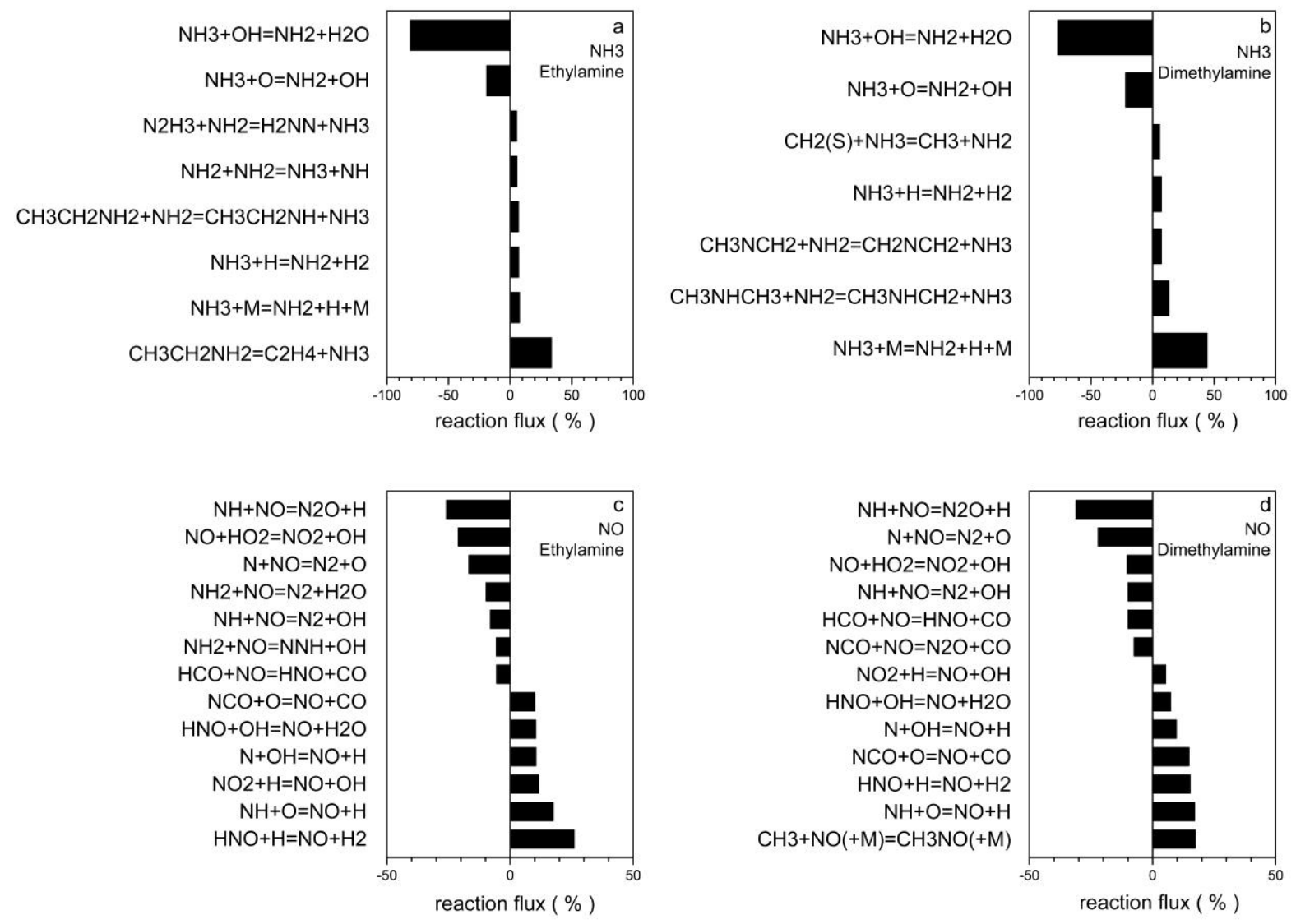
Fig. 17: Mole fraction profiles of $\mathrm{CH}_{3}$ (top) and $\mathrm{CH}_{4}$ (bottom) from experiment (symbols) and simulation (lines).
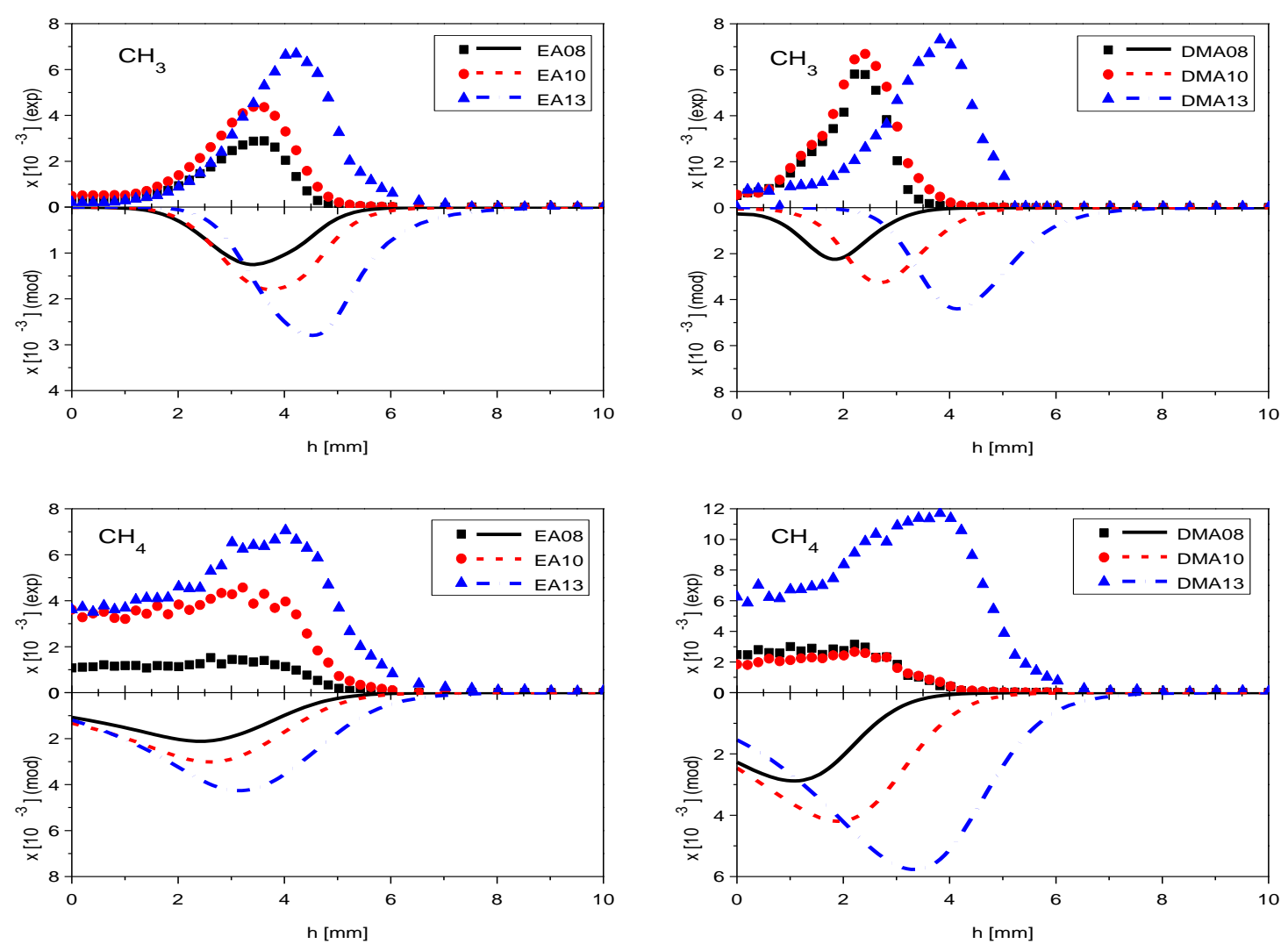
Fig. 18: Mole fraction profiles of $\mathrm{C}_{2} \mathrm{H}_{2}$ (top) and $\mathrm{C}_{2} \mathrm{H}_{4}$ (bottom) from experiment (symbols) and simulation (lines).
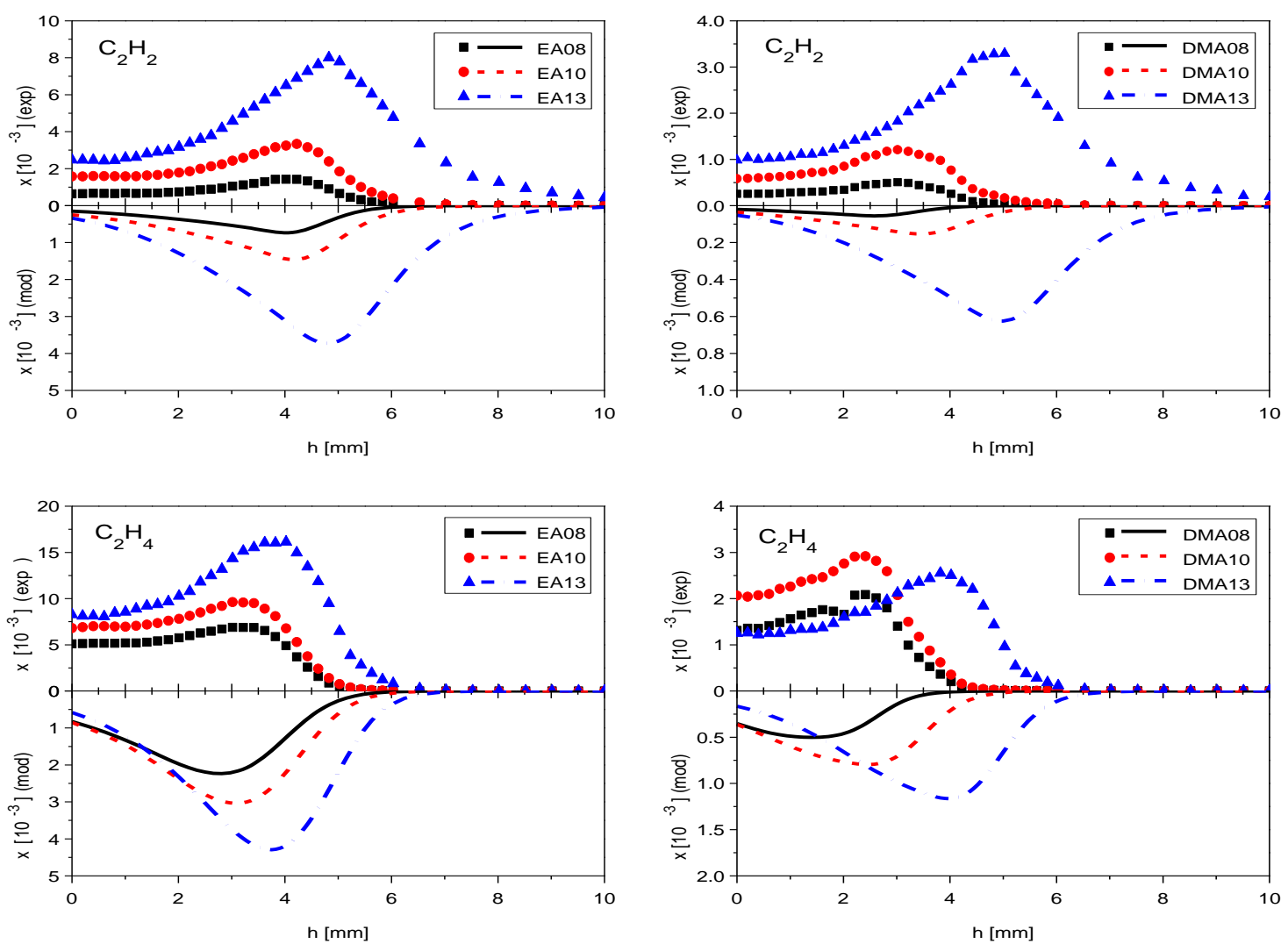
Fig. 19: Mole fraction profiles of $\mathrm{CH}_{3} \mathrm{OH}$ (top) and $\mathrm{CH}_{2} \mathrm{O}$ (bottom) from experiment (symbols) and simulation (lines).
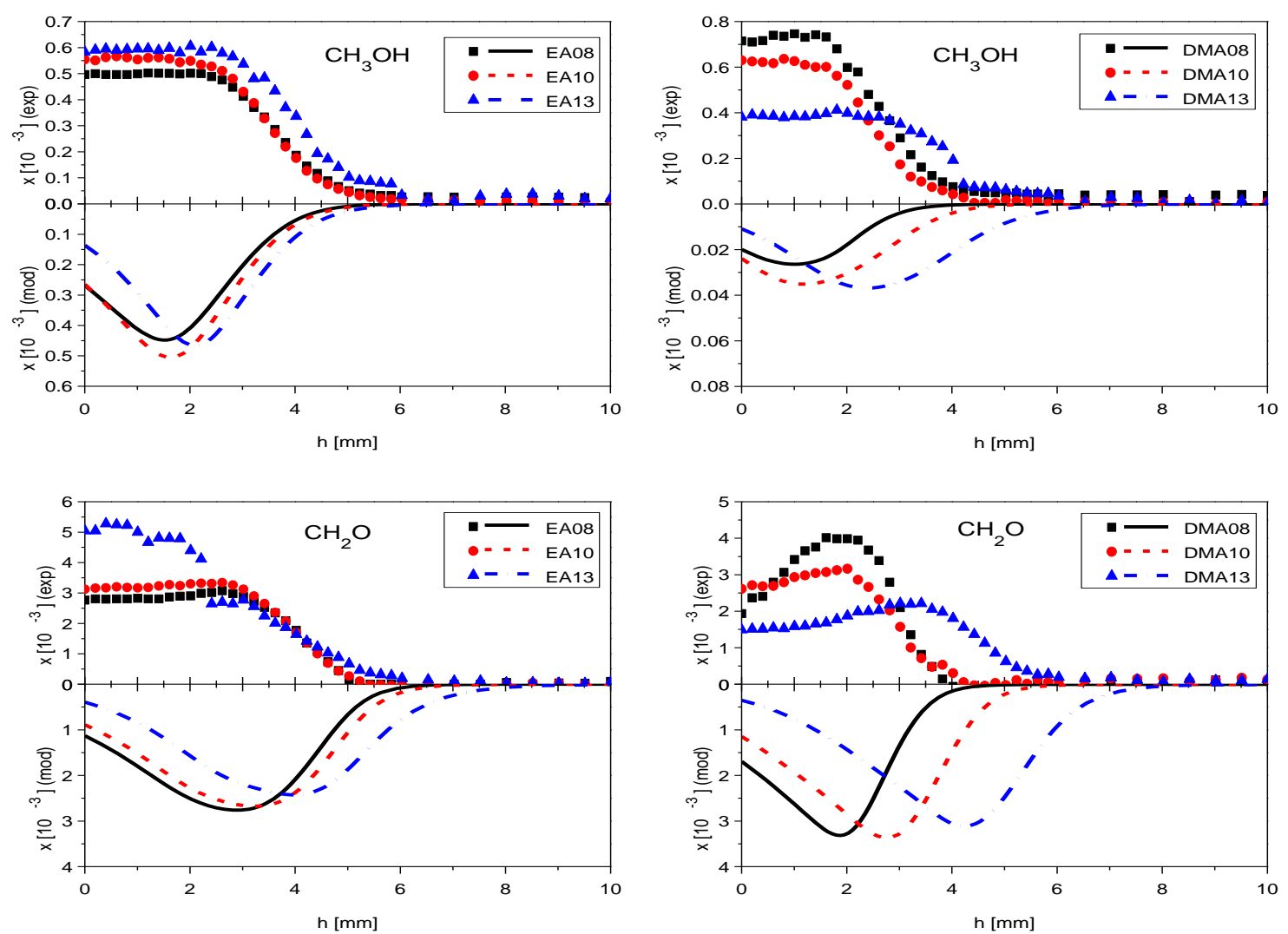